Prepared in cooperation with the Beaver Water District

\title{
Constituent Concentrations, Loads, and Yields to Beaver Lake, Arkansas, Water Years 1999-2008
}

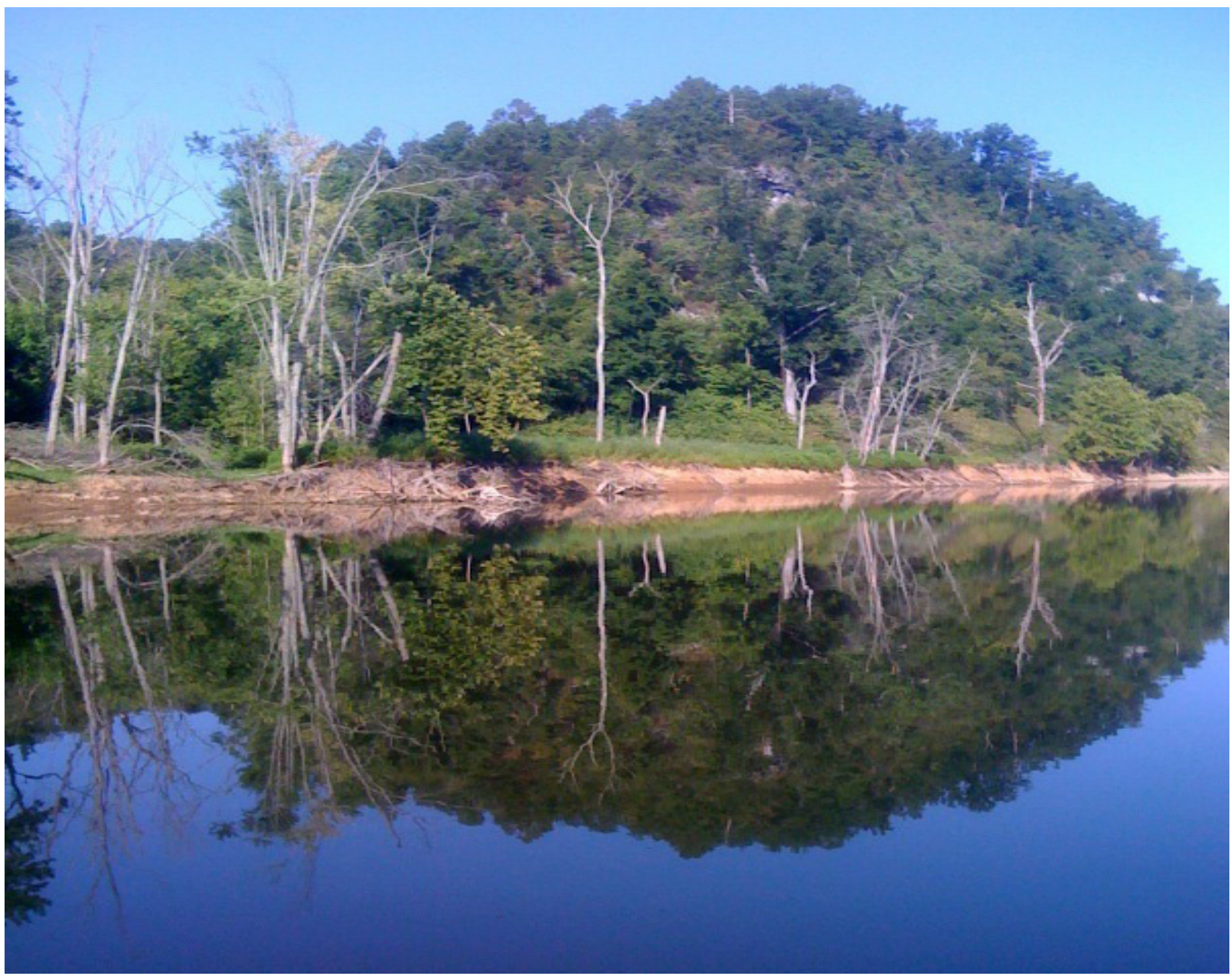

Scientific Investigations Report 2010-5181 
Front cover. War Eagle Creek near Hindsville, Arkansas. Photograph provided by Robert Morgan, Beaver Water District. 


\section{Constituent Concentrations, Loads, and Yields to Beaver Lake, Arkansas, Water Years 1999-2008}

By Susan E. Bolyard, Jeanne L. De Lanois, and W. Reed Green

Prepared in cooperation with the Beaver Water District

Scientific Investigations Report 2010-5181 


\section{U.S. Department of the Interior \\ KEN SALAZAR, Secretary \\ U.S. Geological Survey \\ Marcia K. McNutt, Director}

U.S. Geological Survey, Reston, Virginia: 2010

This and other USGS information products are available at http://store.usgs.gov/
U.S. Geological Survey
Box 25286 , Denver Federal Center
Denver, CO 80225
To learn about the USGS and its information products visit http://www.usgs.gov/
1-888-ASK-USGS

Any use of trade, product, or firm names is for descriptive purposes only and does not imply endorsement by the U.S. Government.

Although this report is in the public domain, permission must be secured from the individual copyright owners to reproduce any copyrighted materials contained within this report.

Suggested citation:

Bolyard, S.E., De Lanois, J.L., and Green, W.R., 2010, Constituent concentrations, loads, and yields to Beaver Lake, Arkansas, water years 1999-2008: U.S. Geological Survey Scientific Investigations Report 2010-5181, 43 p. 


\section{Acknowledgments}

The U.S. Army Corps of Engineers supported the partial-flow streamflow monitoring at White River near Fayetteville and War Eagle Creek near Hindsville. The Arkansas Natural Resources Commission supported some of the water-quality monitoring at White River near Fayetteville. 



\section{Contents}

Abstract

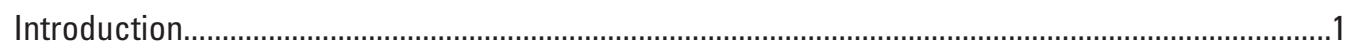

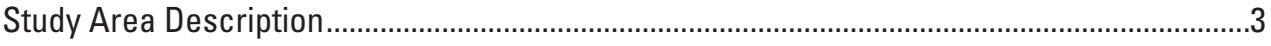

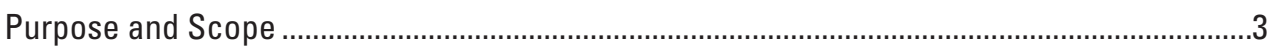

Methods

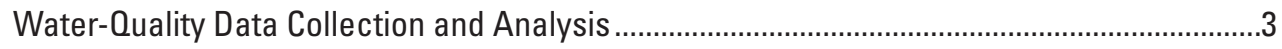

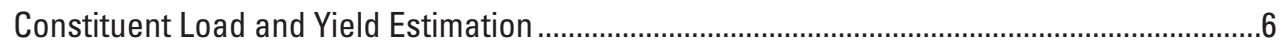

Quality Assurance and Control.................................................................................................

Constituent Concentrations, Loads, and Yields for White River, a Tributary to Beaver Lake,

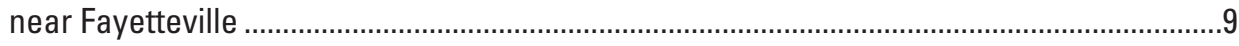

Total Ammonia plus Organic Nitrogen ..............................................................................

Dissolved Nitrite plus Nitrate Nitrogen .................................................................................

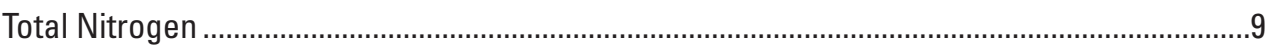

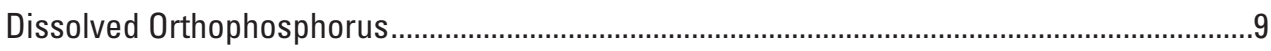

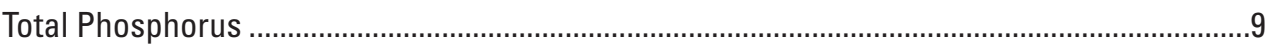

Dissolved Organic Carbon.................................................................................................

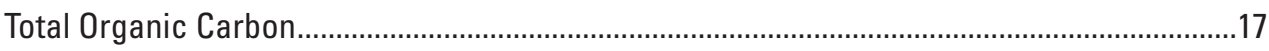

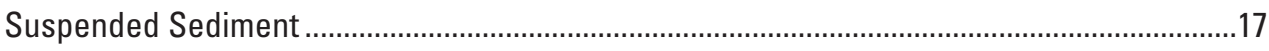

Constituent Concentrations, Loads, and Yields for Richland Creek, a Tributary to Beaver Lake, at Goshen .........................................................................................................

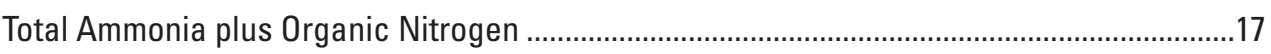

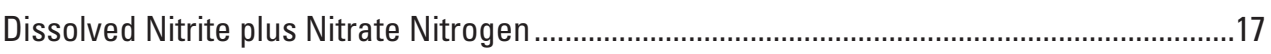

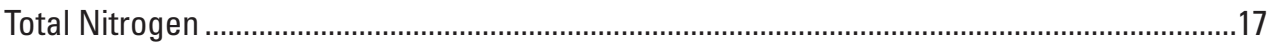

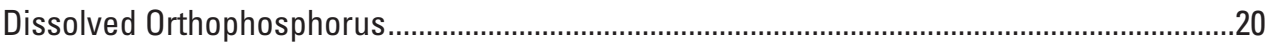

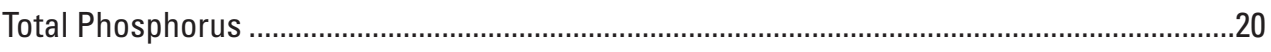

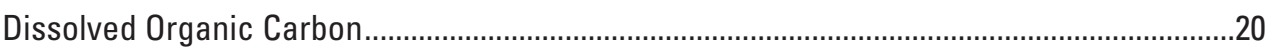

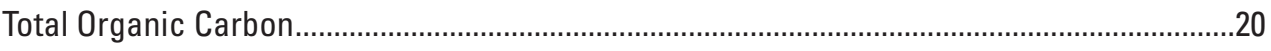

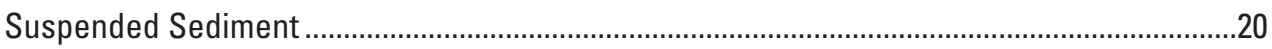

Constituent Concentrations, Loads, and Yields for War Eagle Creek, a Tributary to Beaver

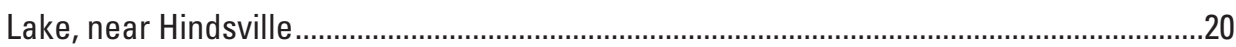

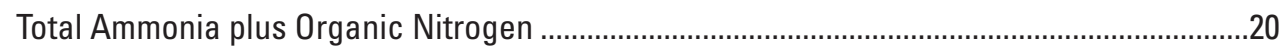

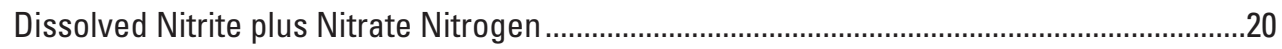

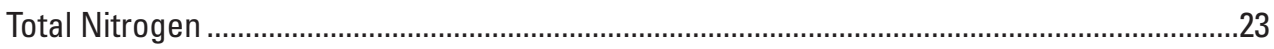

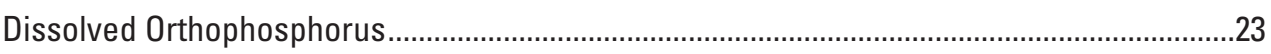

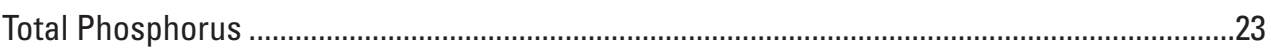

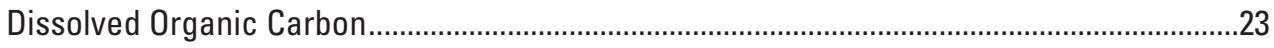

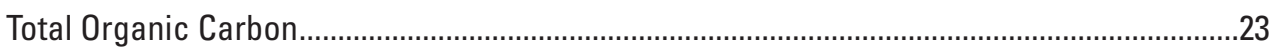

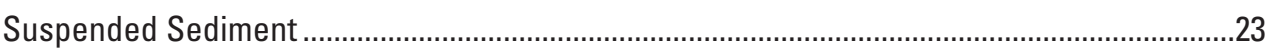

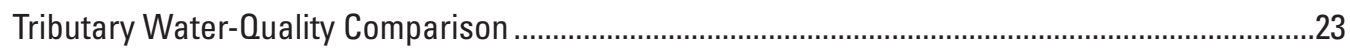

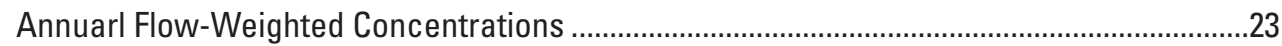

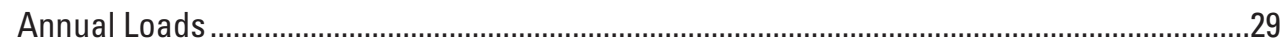

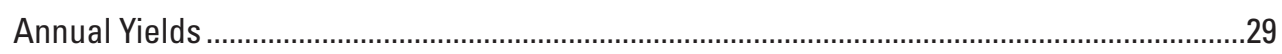


Summary

Appendix 1. Water-quality data results modified from NWIS data for White River near Fayetteville (07048600), Richland Creek at Goshen (07048800), and War Eagle Creek near Hindsville (07049000)

\section{Figures}

1. Map showing Beaver Lake Basin with streamflow and lake water-quality measurement sites

2. Streamflow hydrograph with sample points for White River near Fayetteville, Arkansas, Richland Creek at Goshen, Arkansas, and War Eagle Creek near Hindsville, Arkansas, for water years 1999-2008

3-8. Graphs showing relation between:

3. Nutrient and sediment concentrations and instantaneous streamflow for samples collected at White River near Fayetteville, Arkansas, water years 1999-2008

4. Natural log of instantaneous measured load and natural log of estimated load for samples collected at White River near Fayetteville, Arkansas, water years 1999-2008

5. Nutrient and sediment concentrations and instantaneous streamflow for samples collected at Richland Creek at Goshen, Arkansas, water years 2001-08

6. Natural log of instantaneous measured load and natural log of estimated load for samples collected at Goshen, Arkansas, water years 2001-08

7. Nutrient and sediment concentrations and instantaneous streamflow volume for samples collected at War Eagle Creek near Hindsville, Arkansas, water years 2001-08.

8. Natural log of instantaneous measured load and natural log of estimated load for samples collected at War Eagle Creek near Hindsville, Arkansas, water years 2001-08

9-11. Boxplots showing time series of annual load and streamflow at::

9. White River near Fayetteville, Arkansas, water years 1999-2008 .............................24

10. Richland Creek at Goshen, Arkansas, water years 1999-2008 ....................................25

11. War Eagle Creek near Hindsville, Arkansas, water years 1999-2008 .......................26

12. Graph showing times series of annual flow-weighted concentrations for nutrients, organic carbon, and sediment at White River near Fayetteville, Richland Creek at Goshen, and War Eagle Creek near Hindsville, Arkansas, water years 1999-2008 ........27

13-15. Boxplots showing distributions of:

13. Annual nutrient, organic carbon, and sediment flow-weighted concentrations from water samples collected at White River near Fayetteville, Arkansas, Richland Creek at Goshen, and War Eagle Creek near Hindsville, Arkansas, water years 1999-2008 
14. Annual nutrient, organic carbon, and sediment loads from water samples collected at White River near Fayetteville, Arkansas, Richland Creek at Goshen, and War Eagle Creek near Hindsville, Arkansas, water years 1999-2008.

15. Annual nutrient, organic carbon, and sediment yields from water samples collected at White River near Fayetteville, Arkansas, Richland Creek at Goshen, and War Eagle Creek near Hindsville, Arkansas, water years 1999-2008

\section{Tables}

1. Station information and streamflow statistics for continuous streamflow gaging stations used for water-quality monitoring in the Beaver Lake Basin, Arkansas .............4

2. Regression models developed using constituent concentrations from water samples collected at water-quality stations at the White River near Fayetteville Arkansas, water years 1999-2008, Richland Creek at Goshen, Arkansas, and War Eagle Creek near Hindsville, Arkansas, water years 2001-2008 .

3. Summary statistics of constituent concentrations from water samples collected at water-quality stations for the White River near Fayetteville, Arkansas, water years 1999-2008, Richland Creek at Goshen, Arkansas, and War Eagle Creek near Hindsville, Arkansas, water years 2001-2008.

4. Estimated total annual constituent load from constituent concentrations in water samples collected at water-quality stations for the White River near Fayetteville, Arkansas, water years 1999-2008, Richland Creek at Goshen, Arkansas, and War Eagle Creek near Hindsville, Arkansas, water years 2001-08.

5. Estimated mean annual constituent loads and yield estimated from constituent concentrations in water samples collected at water-quality stations for the White River near Fayetteville, Arkansas, water years 1999-2008, Richland Creek at Goshen, Arkansas, and War Eagle Creek near Hindsville, Arkansas, water years 2001-08

6. Estimated mean annual constituent loads, mean annual streamflows, and mean flow-weighted constituent concentrations at water-quality stations for the White River near Fayetteville, Arkansas, water years 1999-2008, Richland Creek at Goshen, Arkansas, and War Eagle Creek near Hindsville, Arkansas, water years 2001-08 


\section{Conversion Factors}

\begin{tabular}{|c|c|c|}
\hline Multiply & By & To obtain \\
\hline \multicolumn{3}{|c|}{ Length } \\
\hline kilomter (km) & 0.6214 & mile (mi) \\
\hline meter $(\mathrm{m})$ & 3.281 & foot $(\mathrm{ft})$ \\
\hline \multicolumn{3}{|c|}{ Area } \\
\hline square kilometer $\left(\mathrm{km}^{2}\right)$ & 0.3861 & square mile $\left(\mathrm{mi}^{2}\right)$ \\
\hline \multicolumn{3}{|c|}{ Volume } \\
\hline cubic meter $\left(\mathrm{m}^{3}\right)$ & 0.0008107 & acre-foot (acre-ft) \\
\hline \multicolumn{3}{|c|}{ Flow rate } \\
\hline cubit meter per second $\left(\mathrm{m}^{3} / \mathrm{s}\right)$ & 35.315 & cubic foot per second $\left(\mathrm{ft}^{3} / \mathrm{s}\right)$ \\
\hline \multicolumn{3}{|c|}{ Mass } \\
\hline kilogram (kg) & 2.250 & pound avoirdupois (lb) \\
\hline kilogram per day (kg/d) & 2.205 & pound per day (lb/d) \\
\hline kilogram per year (kg/yr) & 2.205 & pound per years $(\mathrm{lg} / \mathrm{yr})$ \\
\hline $\begin{array}{l}\text { kilogram per year per square } \\
\text { kilometer }\left(\mathrm{kg} / \mathrm{yr} / \mathrm{km}^{2}\right)\end{array}$ & 5.710 & $\begin{array}{l}\text { pound per year per square mile } \\
\left(\mathrm{lb} / \mathrm{yr} / \mathrm{mi}^{2}\right)\end{array}$ \\
\hline
\end{tabular}

Vertical coordinate information is referenced to the North American Vertical Datum of 1988 (NAVD 88).)

Horizontal coordinate information is referenced to the North American Datum of 1983 (NAD 83).

Altitude, as used in this report, refers to distance above the vertical datum.

Concentrations of chemical constituents in water are given either in milligrams per liter (mg/L) or micrograms per liter $(\mu \mathrm{g} / \mathrm{L})$.

Estimated concentration ("E" remark code)—Positive detections below the LRL are not censored. Detected analytes with concentrations between the LT-MDL and LRL are reported as estimated ("E" remark code). This is because a detection in this region should have $a<1$ - percent probability of being a false positive (Childress and others, 1999). There are several circumstances that dictate this code; this is one of the most common.

Laboratory reporting level (LRL)—Generally equal to twice the yearly determined LT-MDL. The LRL controls false negative error. The probability of falsely reporting a non-detection for a sample that contained an analyte at a concentration equal to or greater than the LRL is predicted to be less than or equal to 1 percent. The value of the LRL will be reported with a "less than" remark code for samples in which the analyte was not detected. The National Water Quality Laboratory collects quality-control data from selected analytical methods on a continuing basis to determine long-term method detection levels (LT-MDL's) and establish laboratory reporting levels (LRL's). These values are re-evaluated annually based on the most current quality-control data and may, therefore, change (Childress and others, 1999).

Long-term method detection level (LT-MDL)—A detection level derived by determining the standard deviation of a minimum of $24 \mathrm{MDL}$ spike sample measurements over an extended period of time. LT-MDL data are collected on a continuous basis to assess year-to-year variations in the LT-MDL. The LT-MDL controls false positive error. The chance of falsely reporting a concentration at or greater than the LT-MDL for a sample that did not contain the analyte is predicted to be less than or equal to 1 percent (Childress and others, 1999). 
Method detection limit (MDL) - Minimum concentration of a substance that can be measured and reported with 99-percent confidence that the analyte concentration is greater than zero. It is determined from the analysis of a sample in a given matrix containing the analyte (U.S. Environmental Protection Agency, 1997). At the MDL concentration, the risk of a false positive is predicted to be less than or equal to 1 percent (Childress and others, 1999).

Minimum reporting level (MRL) - Smallest measured concentration of a constituent that may be reliably reported by using a given analytical method (Timme, 1995).

Water year (WY)-Is the period October 1 through September 30 designated by the calendar year in which it ends, for example, the 2008 water year runs from 0ctober 1, 2007 to September 30, 2008 (Rantz and others, 1982). 


\title{
Constituent Concentrations, Loads, and Yields to Beaver Lake, Arkansas, Water Years 1999-2008
}

\author{
By Susan E. Bolyard, Jeanne L. De Lanois, and W. Reed Green
}

\section{Abstract}

Beaver Lake is a large, deep-storage reservoir used as a drinking-water supply and considered a primary watershed of concern in the State of Arkansas. As such, information is needed to assess water quality, especially nutrient enrichment, nutrient-algal relations, turbidity, and sediment issues within the reservoir system. Water-quality samples were collected at three main inflows to Beaver Lake: the White River near Fayetteville, Richland Creek at Goshen, and War Eagle Creek near Hindsville. Water-quality samples collected over the period represented different flow conditions (from low to high). Constituent concentrations, flow-weighted concentrations, loads, and yields from White River, Richland Creek, and War Eagle Creek to Beaver Lake for water years 1999-2008 were documented for this report. Constituents include total ammonia plus organic nitrogen, dissolved nitrite plus nitrate nitrogen, dissolved orthophosphorus (soluble reactive phosphorus), total phosphorus, total nitrogen, dissolved organic carbon, total organic carbon, and suspended sediment. Linear regression models developed by computer program S-LOADEST were used to estimate loads for each constituent for the 10-year period at each station. Constituent yields and flow-weighted concentrations for each of the three stations were calculated for the study.

Constituent concentrations and loads and yields varied with time and varied among the three tributaries contributing to Beaver Lake. These differences can result from differences in precipitation, land use, contributions of nutrients from point sources, and variations in basin size. Load and yield estimates varied yearly during the study period, water years 1999-2008, with the least nutrient and sediment load and yields generally occurring in water year 2006, and the greatest occurring in water year 2008, during a year with record amounts of precipitation. Flow-weighted concentrations of most constituents were greatest at War Eagle Creek near Hindsville than White River near Fayetteville and Richland Creek at Goshen. Loads and yields of most constituents were greater at the War Eagle Creek and White River stations than at the Richland Creek Station.

\section{Introduction}

Beaver Lake (fig. 1) is a large, deep-storage reservoir located in the White River Basin in northwestern Arkansas. The reservoir was completed in 1963 for the purposes of flood control, hydroelectric power, and water supply. Beaver Lake is the primary drinking-water supply for northwestern Arkansas. In addition, the reservoir is used for fish and wildlife habitat, and for recreation, and receives wastewater-treatment plant outflow. Because of the importance of Beaver Lake, it is considered a primary watershed of concern for the State of Arkansas. Information is needed to assess water quality, especially nutrient enrichment, nutrient-algal relations, turbidity, and sediment issues within the reservoir system.

The U.S. Geological Survey (USGS) along with the U.S. Army Corps of Engineers (USACE) has monitored streamflow into Beaver Lake since it was impounded in 1963, including a discontinued station at the White River, downstream from Beaver Dam in Table Rock Lake since 1909. In 1999, streamflow-gaging stations at White River near Fayetteville (USGS station number 07048600) and War Eagle Creek near Hindsville (USGS station number 07049000) were converted from partial-record stations (supported by the USACE) to continuous-record stations, and a new streamflow-gaging station was established on Richland Creek at Goshen (USGS station number 07048800), in cooperation with Beaver Water District. Also, periodic water-quality samples were collected at the White River near Fayetteville station in cooperation with Arkansas Soil and Water Conservation Commission, now Arkansas Natural Resources Commission. In 2001, USGS in cooperation with Beaver Water District modified the White River near Fayetteville water-quality sampling and initiated water-quality sampling at both the Richland Creek and War Eagle Creek stations. Water-quality sampling has continued at all three stations to present. Data collected by the USGS in cooperation with Beaver Water District from water years 1999 through 2008 are summarized in this report (appendix 1). A water year is the period October 1 through September 30 designated by the calendar year in which it ends. The USGS, in cooperation with Beaver Water District, used streamflow and 


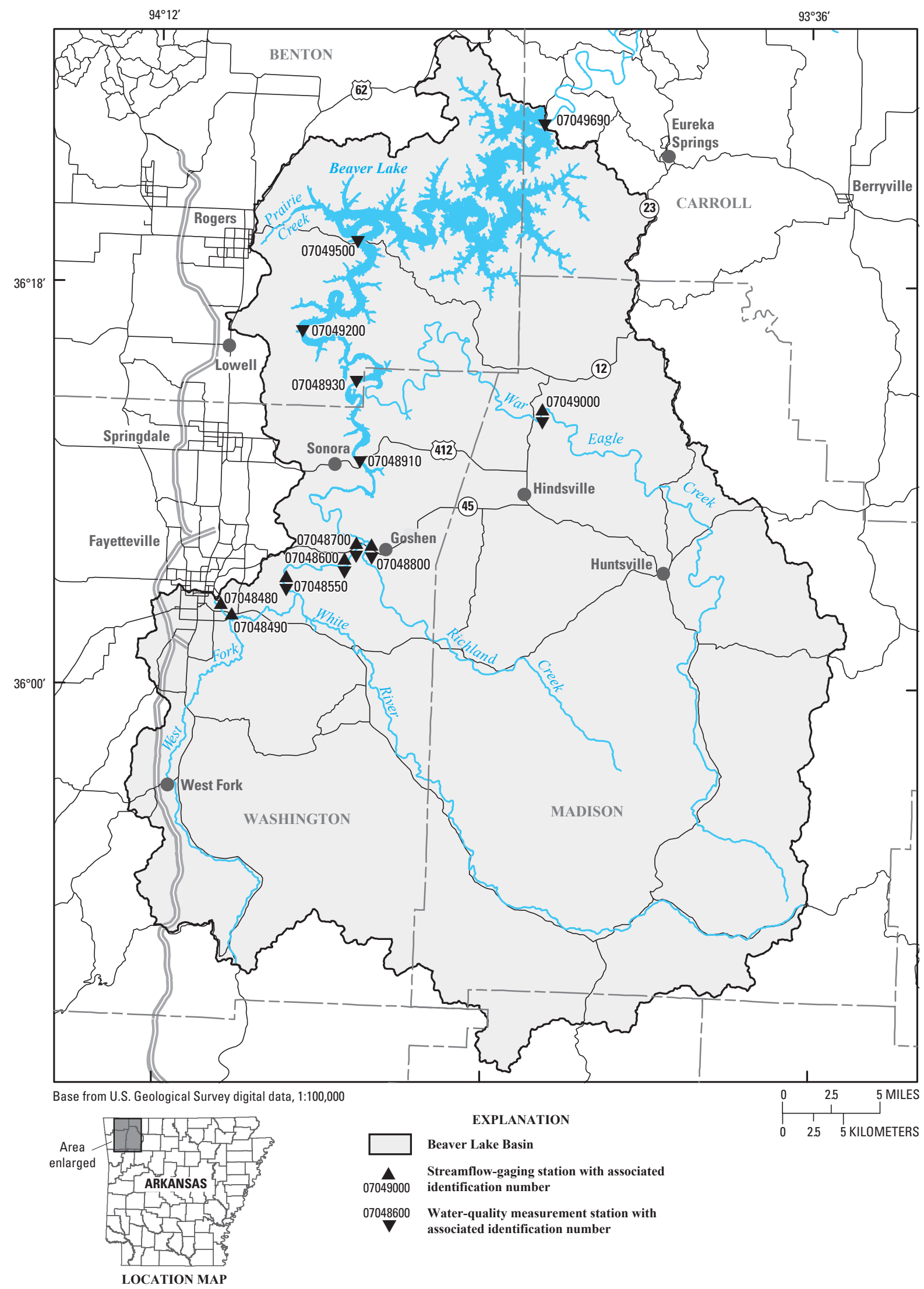

Figure 1. Beaver Lake Basin with streamflow and lake water-quality measurement sites (from Galloway and Green, 2006b). 
water-quality data in a study to evaluate constituent concentrations and loads to Beaver Lake.

\section{Study Area Description}

Beaver Lake was impounded in 1963 on the White River, northeast of the city of Fayetteville, Arkansas, and in 1968, the reservoir reached conservation capacity (Haggard and Green, 2002). The conservation capacity of the reservoir is the storage capacity used for hydroelectric power, water supply, fish and wildlife, recreation, and water quality (U.S. Army Corps of Engineers, 1997). The basin has a drainage area of $3.087 \mathrm{~km}^{2}$ at the Beaver Lake Dam. Beaver Lake contains 6,693 million $\mathrm{m}^{3}(1,653,833$ acre-ft) of water at the top of the current conservation pool (341.5 $\mathrm{m}$ above NAVD of 1988) at a surface area of $114 \mathrm{~km}^{2}$ (Haggard and Green, 2002). The length of the reservoir is $80 \mathrm{~km}$ from the White River at the Highway 45 Bridge to the Beaver Lake Dam. The depth of the reservoir at the dam at conservation pool elevation is $60 \mathrm{~m}$, and the average depth through the reservoir is $17 \mathrm{~m}$ (Haggard and Green, 2002).

Beaver Lake is affected by point and nonpoint sources of nutrients, sediment, and pathogens. The city of Fayetteville discharges about one-half of its treated sewage effluent into the White River immediately upstream from the backwater of the reservoir-however, the discharge is located downstream from the station where the sample was collected (USGS station 07048600). The city of West Fork discharges its treated sewage effluent into the West Fork of the White River, and the city of Huntsville discharges treated sewage effluent into a tributary of War Eagle Creek. Nutrients, sediment, pathogenic bacteria, and other constituents unrelated to municipal wastewater also can enter Beaver Lake through its tributaries and around its shoreline. The greatest increase in population in the State of Arkansas from 1990 to 2000 occurred in Benton, Washington, and Carroll Counties in northwestern Arkansas surrounding Beaver Lake where the population increased from approximately 239,000 to 335,000 (U.S. Census Bureau, 2009). The principal agricultural activity in the area is poultry production and secondarily, cattle production. As a result of all these factors, there is substantial concern about the current and future water quality of Beaver Lake.

The main inflows into Beaver Lake are the White River, Richland Creek, and War Eagle Creek (fig. 1). Several smaller tributaries also flow into the reservoir. The Basin has a drainage area of 2,968 $\mathrm{km}^{2}$ upstream from Beaver Lake Dam. The White River is the largest tributary to Beaver Lake with a drainage area of $1,040 \mathrm{~km}^{2}$ upstream from the streamflowgaging station near Fayetteville (White River near Fayetteville, Arkansas, USGS station number 07048600), composing approximately 35 percent of the drainage area of Beaver Lake at the dam. War Eagle Creek is the second largest tributary to Beaver Lake with a drainage area of $681 \mathrm{~km}^{2}$ at the streamflow-gaging station near Hindsville (War Eagle Creek near Hindsville, Arkansas, USGS station number 07049000), composing approximately 22 percent of the Beaver Lake Basin upstream from the dam. Richland Creek is another major tributary to Beaver Lake, with a drainage area of 357 $\mathrm{km}^{2}$ upstream from the streamflow-gaging station at Goshen (Richland Creek at Goshen, Arkansas, USGS station number 07048800), composing approximately 12 percent of the drainage area of Beaver Lake upstream from the dam. Combined, these three tributaries (at the streamflow-gaging stations) represent approximately 69 percent of the total drainage area of Beaver Lake.

\section{Purpose and Scope}

The purpose of this report is to describe constituent concentrations, flow-weighted concentrations, loads, and yields to Beaver Lake for White River, Richland Creek, and War Eagle Creek for the study period, water years 1999-2008. Constituents include total ammonia plus organic nitrogen, dissolved nitrite plus nitrate nitrogen, total nitrogen, dissolved orthophosphorus (soluble reactive phosphorus), total phosphorus, dissolved organic carbon, total organic carbon, and suspended sediment.

\section{Methods}

\section{Water-Quality Data Collection and Analysis}

The USGS operates 7 continuous streamflow-gaging stations and 10 water-quality sampling stations in the Beaver Lake Basin in northwestern Arkansas (fig. 1). Three streamflow-gaging stations with water-quality sampling at the same stations were selected for use in this report: White River near Fayetteville, Arkansas (USGS station 07048600), Richland Creek at Goshen, Arkansas (USGS station 07048800), and War Eagle Creek near Hindsville, Arkansas (USGS station 07049000) (table 1, fig. 1). Stream gages were operated and streamflows were measured according to the methods described in Rantz and others (1982). Streamflow, in cubic feet per second, was computed every 15 minutes and averaged daily from 1999 through 2008 (and continues) at White River near Fayetteville, Richland Creek at Goshen, and War Eagle Creek near Hindsville, and was converted to cubic meters per second for this report (fig. 1, table 1). Water-quality samples, with corresponding instantaneous streamflows (streamflow at the time of sample collection), were collected during low-, moderate-, and high-flow conditions (fig. 2). The White River near Fayetteville water-quality sampling record began with bimonthly (occurring every 2 months) and high-flow event sampling from November 1999 through October 2000. Monthly and high-flow event samples were collected at the White River near Fayetteville beginning in January 2001 and at Richland Creek at Goshen and War Eagle Creek near 


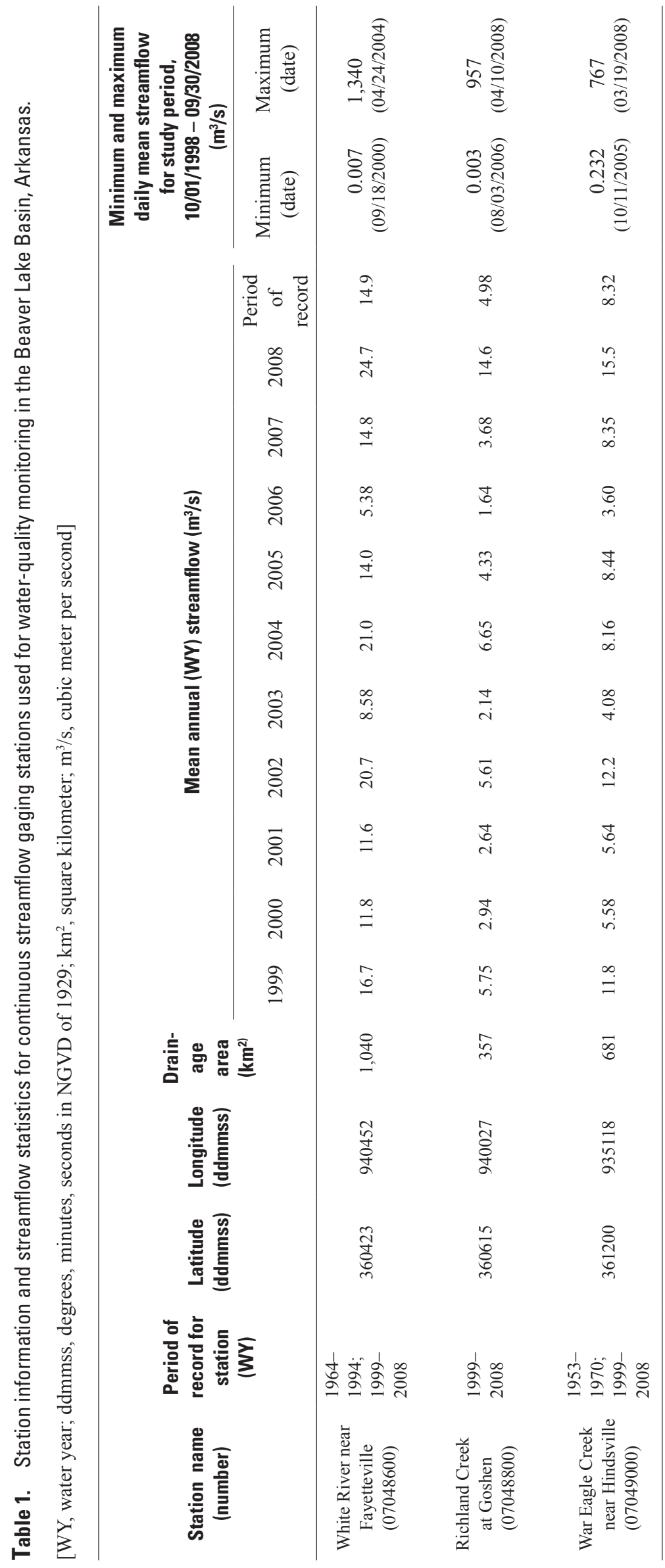



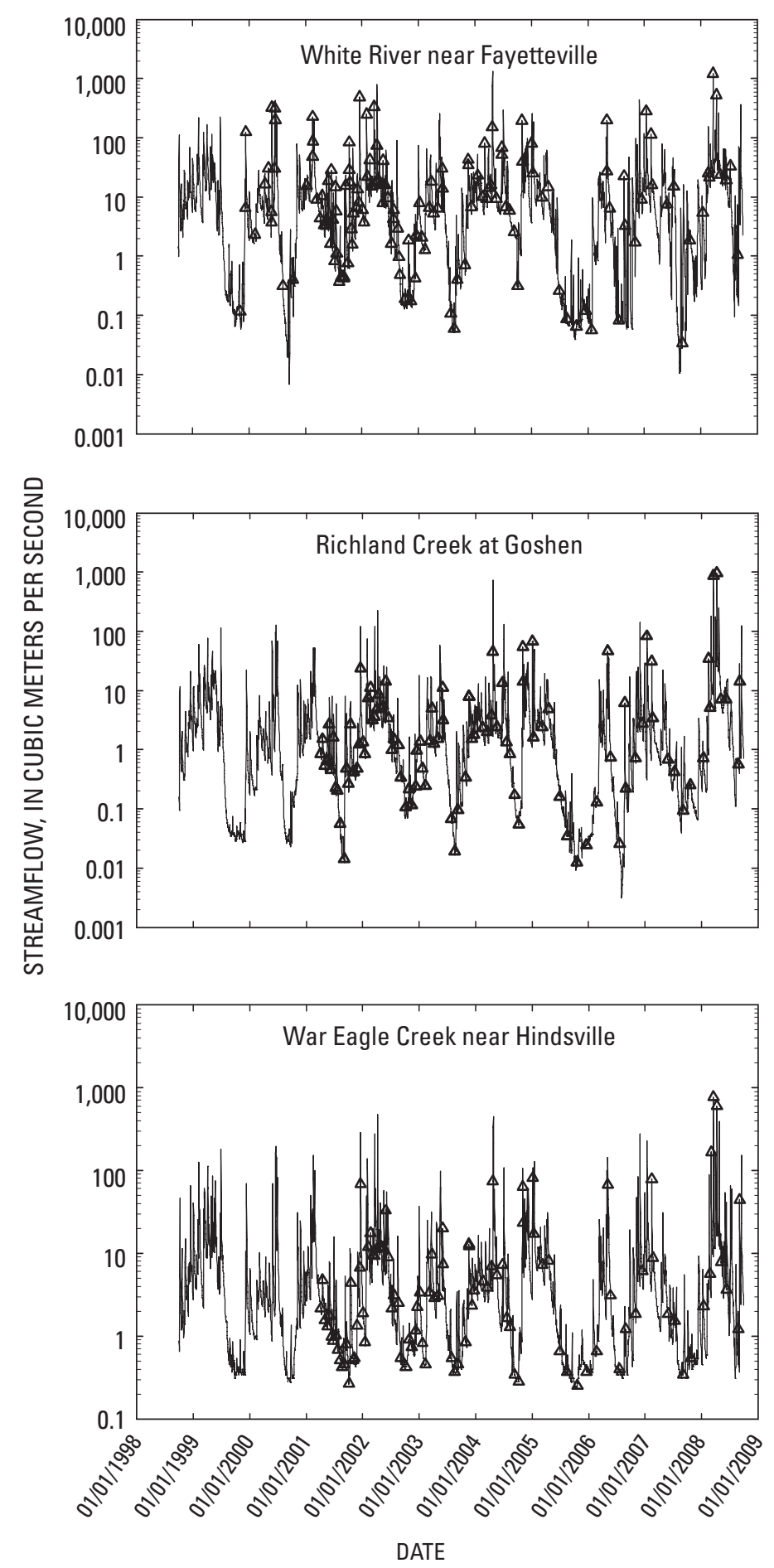

EXPLANATION

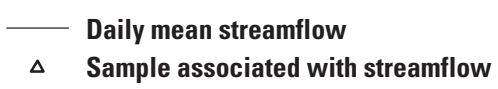

Figure 2. Streamflow hydrograph with sample points for White River near Fayetteville, Arkansas, Richland Creek at Goshen, Arkansas, and War Eagle Creek near Hindsville, Arkansas, for water years 1999-2008. 
Hindsville beginning in April 2001. Samples were collected through November 2004. Bimonthly and high-flow event samples were collected at all three stations from January 2005 through September 2008. Representative water-quality samples were collected using equal-width increment methods (Edwards and Glysson, 1999).

The USGS National Water Quality Laboratory in Lakewood, Colorado, analyzed the water-quality samples for total ammonia plus organic nitrogen, dissolved nitrite plus nitrate, dissolved orthophosphorus, total phosphorus, total nitrogen (Fishman, 1993), dissolved organic carbon (Brenton and Arnett, 1993), and total organic carbon (Wershaw and others, 1987). Constituent concentrations were reported as uncensored values if they were greater than the laboratory reporting level (LRL). The LRL is set to reduce false positive error and is equal to twice the yearly determined long-term method detection level (LT-MDL). When the constituent was not detected, the LRL value was reported with a "less than" remark code and was considered a censored value. Estimated values with concentrations between the LT-MDL and the LRL are reported with an "E" remark code because of low confidence in the value (Childress and others, 1999). For the purposes of describing the mean and computing loads, censored values were converted to the LT-MDL value (with the "less than" remark code), if the LRL was reported at the time of the sample analysis, and "E" remark codes were removed. If the censored values were reported as less than the LT-MDL at the time of analysis, no alteration was made. The modified waterquality values with remark codes described above, which were used to determine the mean and loads, are found in the appendix (appendix 1).

Suspended-sediment samples were collected during low-, moderate-, and high-flow conditions. The USGS Missouri Water Science Center Sediment Laboratory in Rolla, Missouri, analyzed samples for suspended-sediment concentration following procedures established in Guy (1969).

Streamflow data measured from October 1998 through December 2008 are presented in this report. All streamflow data described are available on the web at $h t t p: / / w a t e r . u s g s$. gov/ar/nwis.

\section{Constituent Load and Yield Estimation}

Linear regression models developed by computer program S-LOADEST were used to estimate loads for each constituent for the 10-year period at each station (table 2). Data from all three tributaries generally appeared to fit the models. Load is the mass of a constituent transported past a selected point in a stream in a given amount of time, usually 1 year. The S-LOADEST program (TIBCO Software Inc., 2008) was used to estimate constituent loads by the rating-curve method (Cohn and others, 1989; Crawford, 1991) for the White River, Richland Creek, and War Eagle Creek stations. S-LOADEST estimates loads using mean daily streamflow, streamflow rating-curve parameters, several regression methods, and a ratio estimator. Because some of the constituent concentrations included in the S-LOADEST analyses were censored values, parameters were estimated by the adjusted maximum likelihood estimation (AMLE) method (Cohn, 1988; Cohn and others, 1992). In the absence of censored data, the method converts to the maximum likelihood estimation (MLE) method (Dempster and others, 1977; Wolynetz, 1979). Uncertainty in the estimated load was obtained using the method described by Likes (1980) and Gilroy and others (1990). The model (equation 1) used to calculate loads was based on the relation between the natural logarithms of $\mathrm{L}$ and Q:

$$
\ln (L)=b_{0}+b_{1} \ln (Q)
$$

where

$$
\begin{aligned}
& \text { In is natural logarithm; } \\
& L \quad \text { is constituent load, in kilograms per day } \\
& (\mathrm{kg} / \mathrm{d}) \text {; } \\
& b_{0} \quad \text { is regression constant, dimensionless; } \\
& b_{1} \quad \text { is a regression coefficient, dimensionless; } \\
& Q \quad \text { is daily mean streamflow, in cubic meters } \\
& \text { per second }\left(\mathrm{m}^{3} / \mathrm{s}\right) \text {. }
\end{aligned}
$$

Estimated mean annual constituent loads and standard error of prediction (SEP) of the mean loads were calculated by S-LOADEST using all available data for each constituent for the 10 -year period. The coefficient of determination $\left(R^{2}\right)$ is the proportion of variability in the data set that is accounted for by the statistical model. For this report, an $\mathrm{R}^{2}$ value of 0.90 or greater was considered a valid regression model. $\mathrm{R}^{2}$ values less than 0.90, which demonstrates a positive relation, were not considered valid. Estimated residual variance is the maximum likelihood estimation variance corrected for the number of observations, number of censored observations, and number of parameters in the regression model.

The 95-percent confidence interval is the interval that has a 95-percent chance of containing the true regression line. In contrast, the 95-percent prediction interval is the interval in which you expect 95 percent of all data points to fall. A major factor determining the width of a confidence interval is the size of the sample used in the estimation procedure, with smaller samples having wider confidence intervals (Helsel and Hirsch, 2002).

Constituent yields for each of the three stations were calculated by dividing mean annual constituent load by the drainage area, in square kilometers (table 1). Flow-weighted concentrations for each of the three stations were calculated by dividing mean annual constituent loads by mean annual streamflow and multiplying by a conversion factor to adjust the units.

Linear regression was used to examine the relations between estimated daily loads and measured instantaneous loads, both reported in kilograms per day. Instantaneous load is calculated by multiplying streamflow, in cubic meters per second, constituent concentration, in milligrams per liter, and a conversion factor to convert to kilograms per day. The 


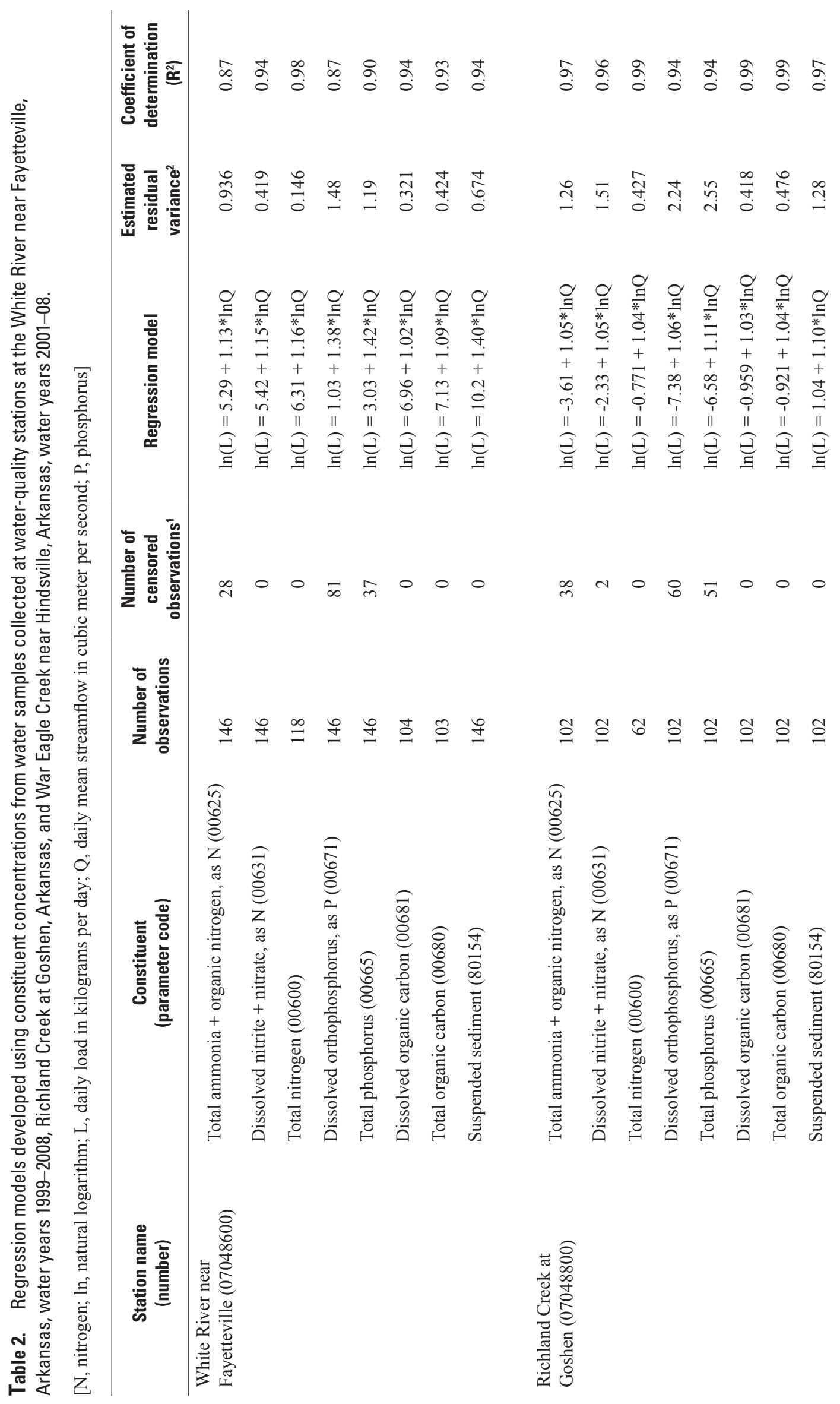




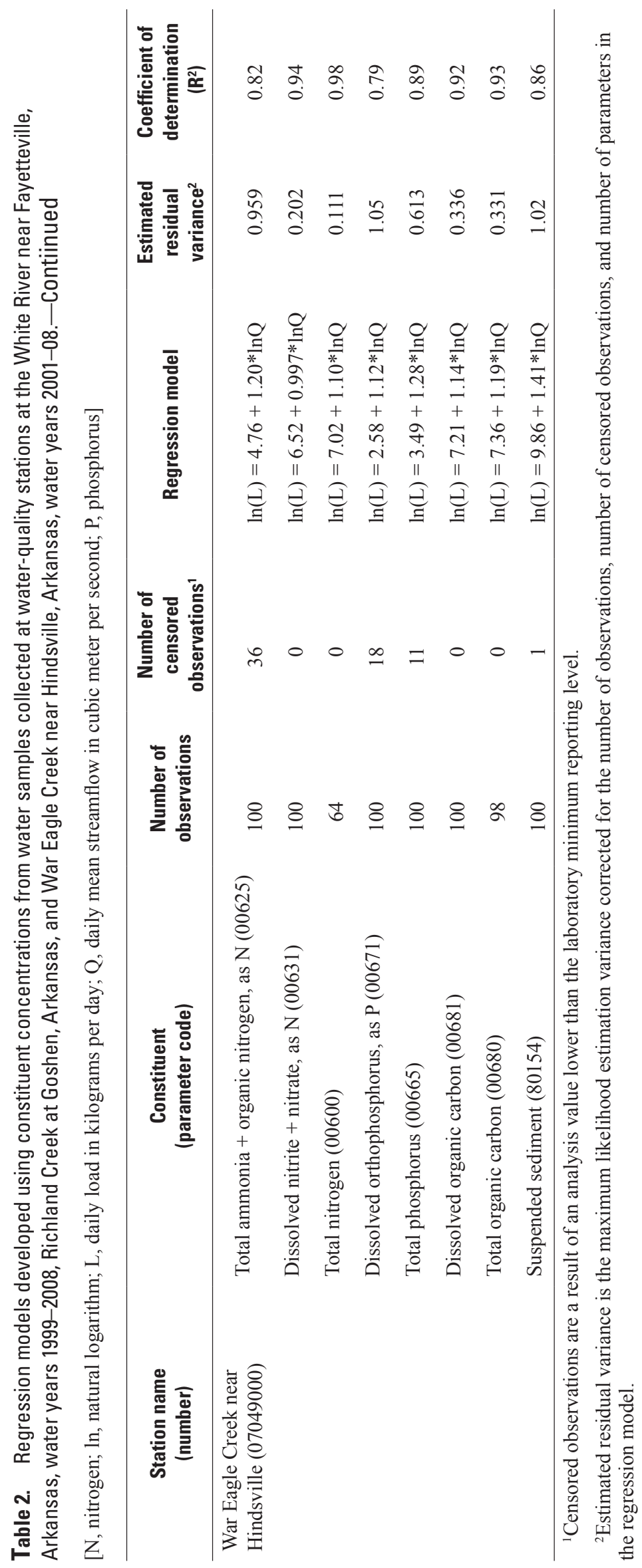


slope of the regression relates to how well the loading model estimates constituent loading. A line originating at zero with a slope of 1.0 would be the ideal relation.

Means, along with maxima, minima, and medians, were determined by an S-Plus software (TIBCO Software Inc., 2008) data summary statistics application applied to the data in appendix 1 (table 3).

\section{Quality Assurance and Control}

Field methods were conducted following procedures described in the USGS National Field Manual (U.S. Geological Survey, variously dated). Nutrient, total organic carbon, and dissolved organic carbon analyses were conducted at the USGS National Water Quality Laboratory in Denver, Colorado, following procedures described in Fishman (1993). SSC analyses were conducted at the USGS laboratory in Rolla, Missouri, following procedures described in Guy (1969). Field measurements, including water temperature, dissolvedoxygen concentration, $\mathrm{pH}$, and specific conductance also were collected with each sample following protocols described in Wilde and Radke (1998).

To maintain proper quality assurance and control (QA) QC) of water-quality data, protocols for instrument calibration (Wilde and Radke, 1998) and equipment cleaning (Wilde and others, 1998) were followed. Associated blank and replicate water-quality samples also were collected by USGS personnel periodically. Results indicated that cleaning procedures were adequate in preventing cross-contamination of samples and that the laboratory results were reproducible. Results for QA/ QC samples are available at the USGS National Water Information System webpage (http://waterdata.usgs.gov/nwis) and can be obtained through the USGS Arkansas Water Science Center in Little Rock, Arkansas.

\section{Constituent Concentrations, Loads, and Yields for White River, a Tributary to Beaver Lake, near Fayetteville}

\section{Total Ammonia plus Organic Nitrogen}

Total ammonia plus organic nitrogen concentrations for White River near Fayetteville ranged from less than 0.06 to $2.6 \mathrm{mg} / \mathrm{L}$ as $\mathrm{N}$ with a mean concentration of $0.48 \mathrm{mg} / \mathrm{L}$ as N (table 3). Concentrations tended to increase with increasing streamflow (fig. 3). Loads were estimated as a function of streamflow $\left(\mathrm{R}^{2}=0.87\right.$; table 2$)$. These estimated loads then were compared to instantaneous measured load with a slope of 0.88 (fig. 4). For total ammonia plus organic nitrogen, the 10-year mean load was $294,000 \mathrm{~kg} / \mathrm{yr}$ as N (table 4) and mean yield was $283 \mathrm{~kg} / \mathrm{yr} / \mathrm{km}^{2}$ as $\mathrm{N}$ (table 5). Estimated mean annual flow-weighted concentration was $0.61 \mathrm{mg} / \mathrm{L}$ as N (table $6)$.

\section{Dissolved Nitrite plus Nitrate Nitrogen}

Dissolved nitrite plus nitrate concentrations for White River near Fayetteville ranged from 0.03 to $1.4 \mathrm{mg} / \mathrm{L}$ as $\mathrm{N}$ with a mean concentration of $0.44 \mathrm{mg} / \mathrm{L}$ as $\mathrm{N}$ (table 3 ). Concentrations tended to increase with increasing streamflow (fig. 3). Loads were estimated as a function of streamflow $\left(\mathrm{R}^{2}\right.$ $=0.94$; table 2 ). These estimated loads were then compared to instantaneous measured load with a slope of 0.90 (fig. 4). For dissolved nitrate plus nitrite, the 10-year mean load was $273,000 \mathrm{~kg} / \mathrm{yr}$ as N (table 4) and mean yield was $262 \mathrm{~kg} / \mathrm{yr} /$ $\mathrm{km}^{2}$ as $\mathrm{N}$ (table 5). Estimated mean annual flow-weighted concentration was $0.57 \mathrm{mg} / \mathrm{L}$ as $\mathrm{N}$ (table 6).

\section{Total Nitrogen}

Total nitrogen concentrations for White River near Fayetteville ranged from 0.31 to $3.0 \mathrm{mg} / \mathrm{L}$ with a mean concentration of $0.98 \mathrm{mg} / \mathrm{L}$ (table 3 ). Concentrations tended to increase with increasing streamflow (fig. 3). Loads were estimated as a function of streamflow $\left(\mathrm{R}^{2}=0.98\right.$; table 2$)$. These estimated loads were then compared to instantaneous measured load with a slope of 0.94 (fig. 4). For total nitrogen, the 10-year mean load was 593,000 kg/yr (table 4) and mean yield was $570 \mathrm{~kg} / \mathrm{yr} / \mathrm{km}^{2}$ (table 5). Estimated mean annual flowweighted concentration was $1.23 \mathrm{mg} / \mathrm{L}$ (table 6).

\section{Dissolved Orthophosphorus}

Dissolved orthophosphorus concentrations for White River near Fayetteville ranged from less than 0.003 to 0.110 $\mathrm{mg} / \mathrm{L}$ as $\mathrm{P}$ with a mean concentration of $0.015 \mathrm{mg} / \mathrm{L}$ as $\mathrm{P}$ (table $3)$. Concentrations tended to increase slightly with increasing streamflow (fig. 3). Loads were estimated as a function of streamflow $\left(\mathrm{R}^{2}=0.87\right.$; table 2$)$. These estimated loads were then compared to instantaneous measured load with a slope of 1.09 (fig. 4). For dissolved orthophosphorus, the 10-year mean load was $10,300 \mathrm{~kg} / \mathrm{yr}$ as P (table 4 ) and mean yield was $10 \mathrm{~kg} / \mathrm{yr} / \mathrm{km}^{2}$ as $\mathrm{P}$ (table 5). Estimated mean annual flowweighted concentration was $0.02 \mathrm{mg} / \mathrm{L}$ as $\mathrm{P}$ (table 6).

\section{Total Phosphorus}

Total phosphorus concentrations for White River near Fayetteville ranged from less than 0.010 to $0.600 \mathrm{mg} / \mathrm{L}$ with a mean concentration of $0.084 \mathrm{mg} / \mathrm{L}$ (table 3 ). Concentrations tended to increase with increasing streamflow (fig. 3). Loads were estimated as a function of streamflow $\left(\mathrm{R}^{2}=0.90\right.$; table 2). These estimated loads were then compared to instantaneous measured load with a slope of 0.96 (fig. 4). For total phosphorus, the 10-year mean load was 73,200 kg/yr (table 4) 


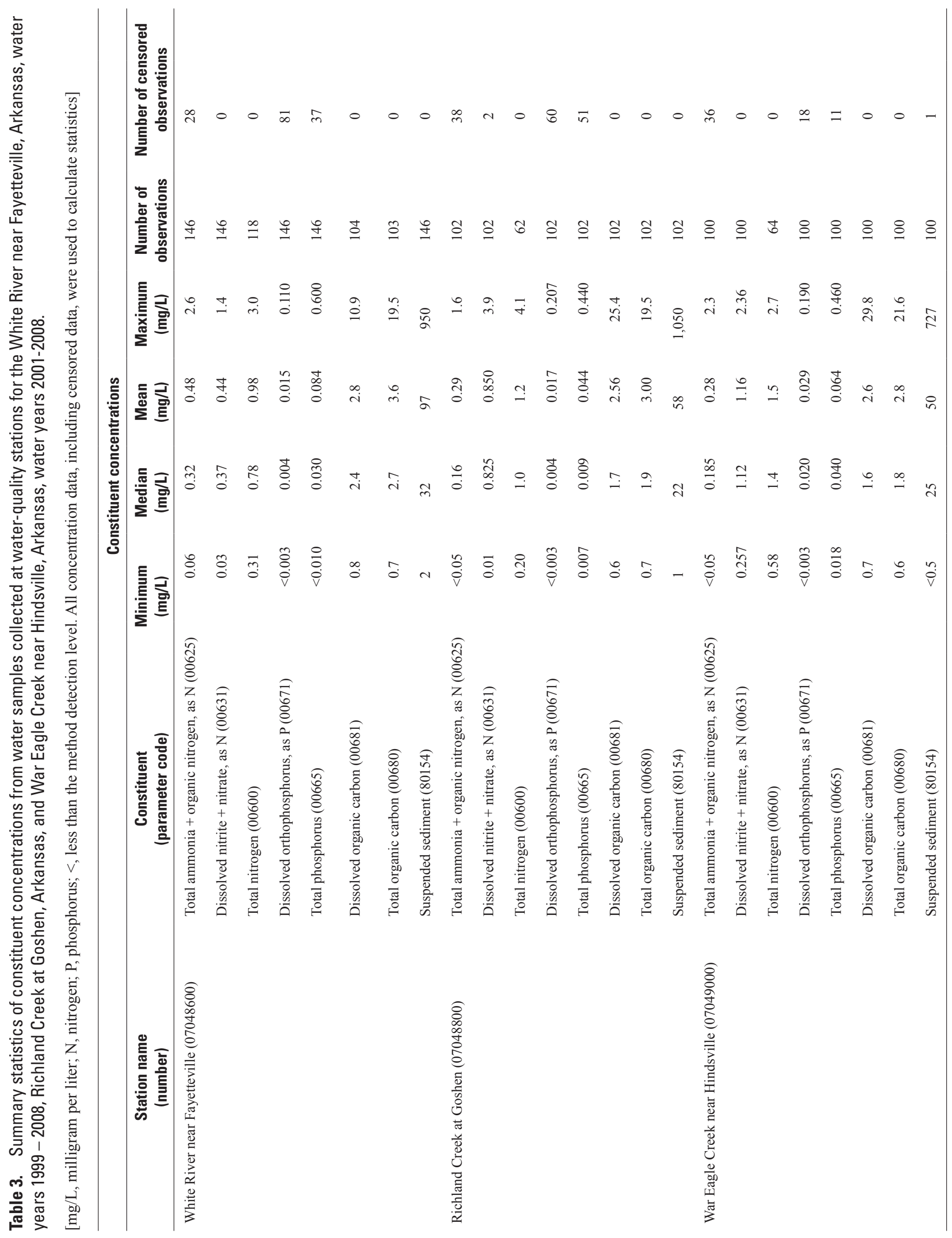



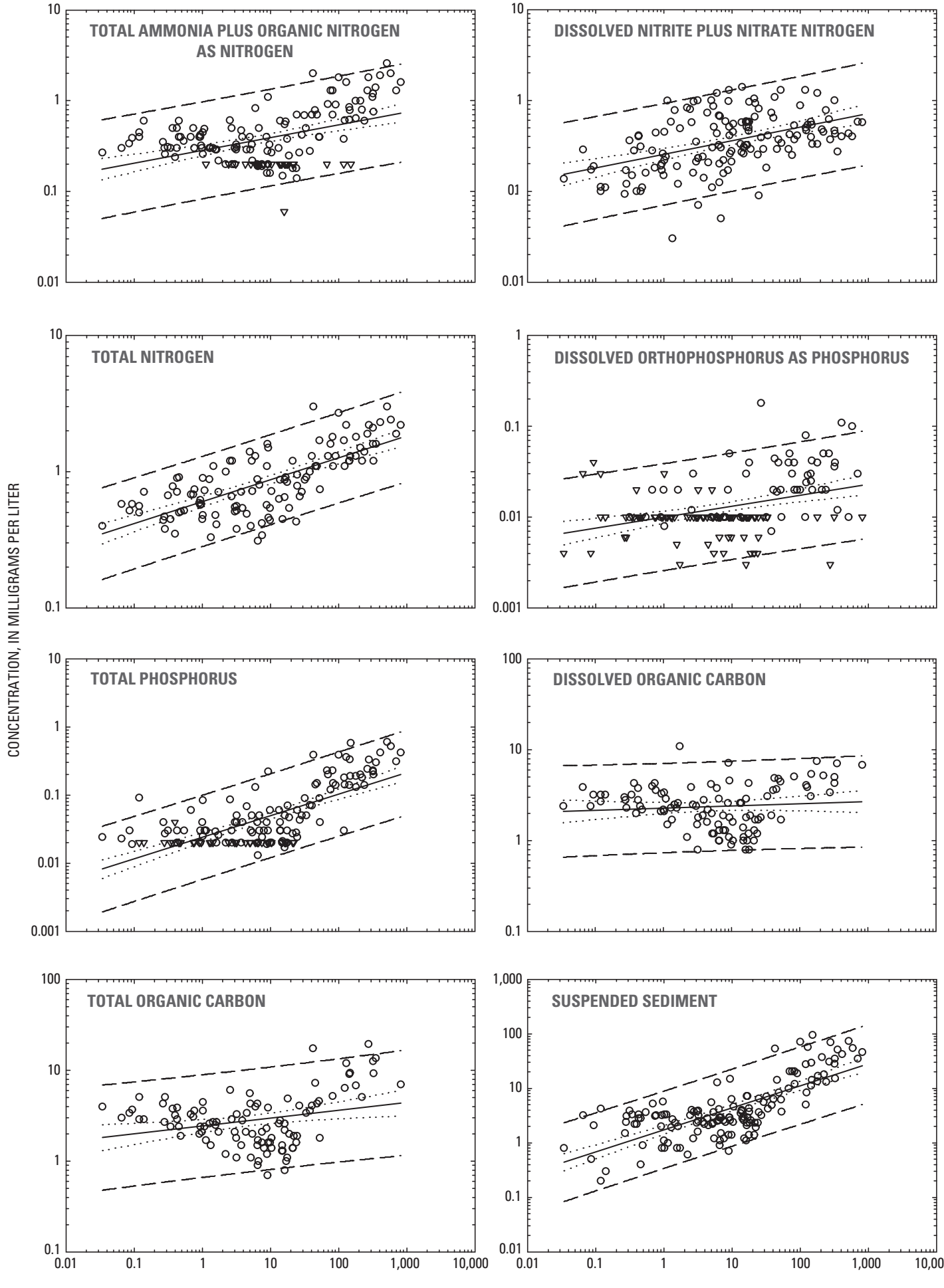

INSTANTANEOUS STREAMFLOW, IN CUBIC METERS PER SECOND

\section{EXPLANATION}

$\begin{array}{cl}-\ldots \ldots & \text { Regression line } \\ \ldots \ldots & 95 \text { percent confidence interval of the regression } \\ - & 95 \text { percent confidence interval of the prediction } \\ \nabla & \text { Censored sample value } \\ \circ \quad & \text { Measured sample value }\end{array}$

Figure 3. Relation between nutrient and sediment concentrations and instantaneous streamflow for samples collected at White River near Fayetteville, Arkansas, water years 1999-2008. 

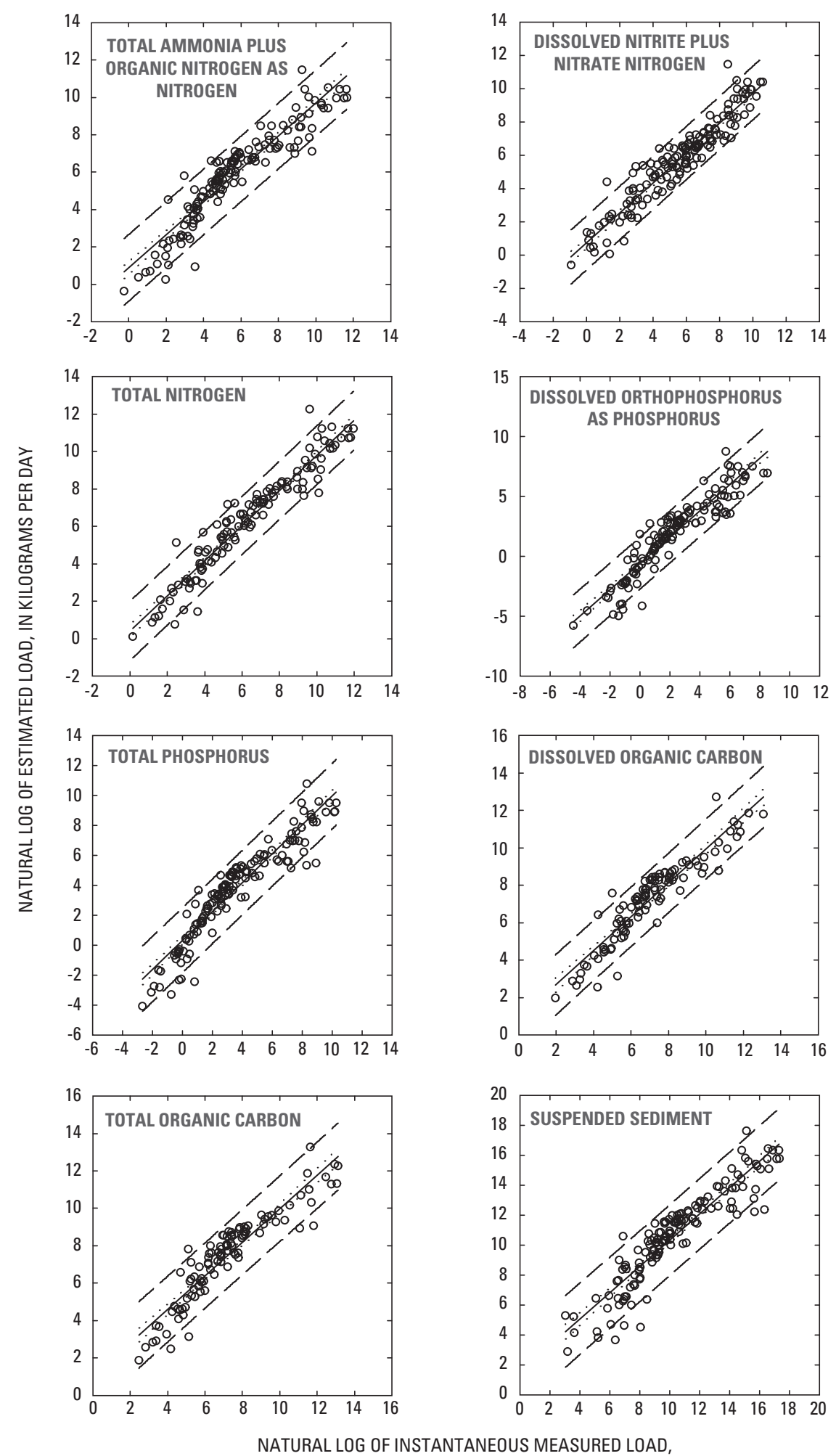

IN KILOGRAMS PER DAY

EXPLANATION

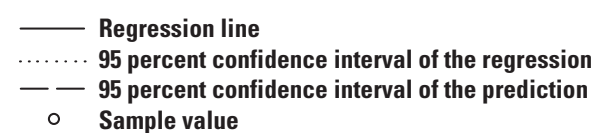

Figure 4. Relation between natural log of instantaneous measured load and natural log of estimated load for samples collected at White River near Fayetteville, Arkansas, water years 1999-2008. 


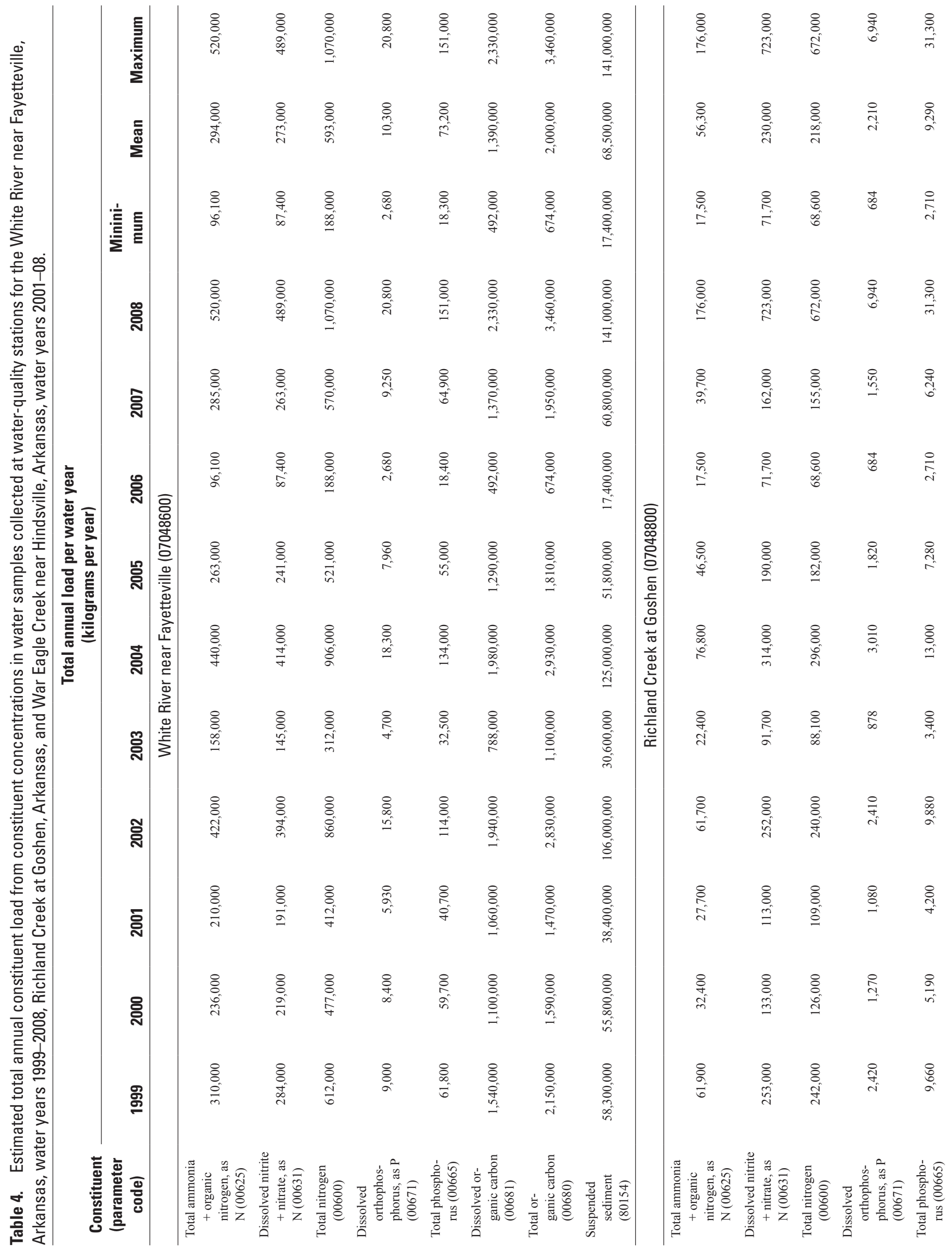




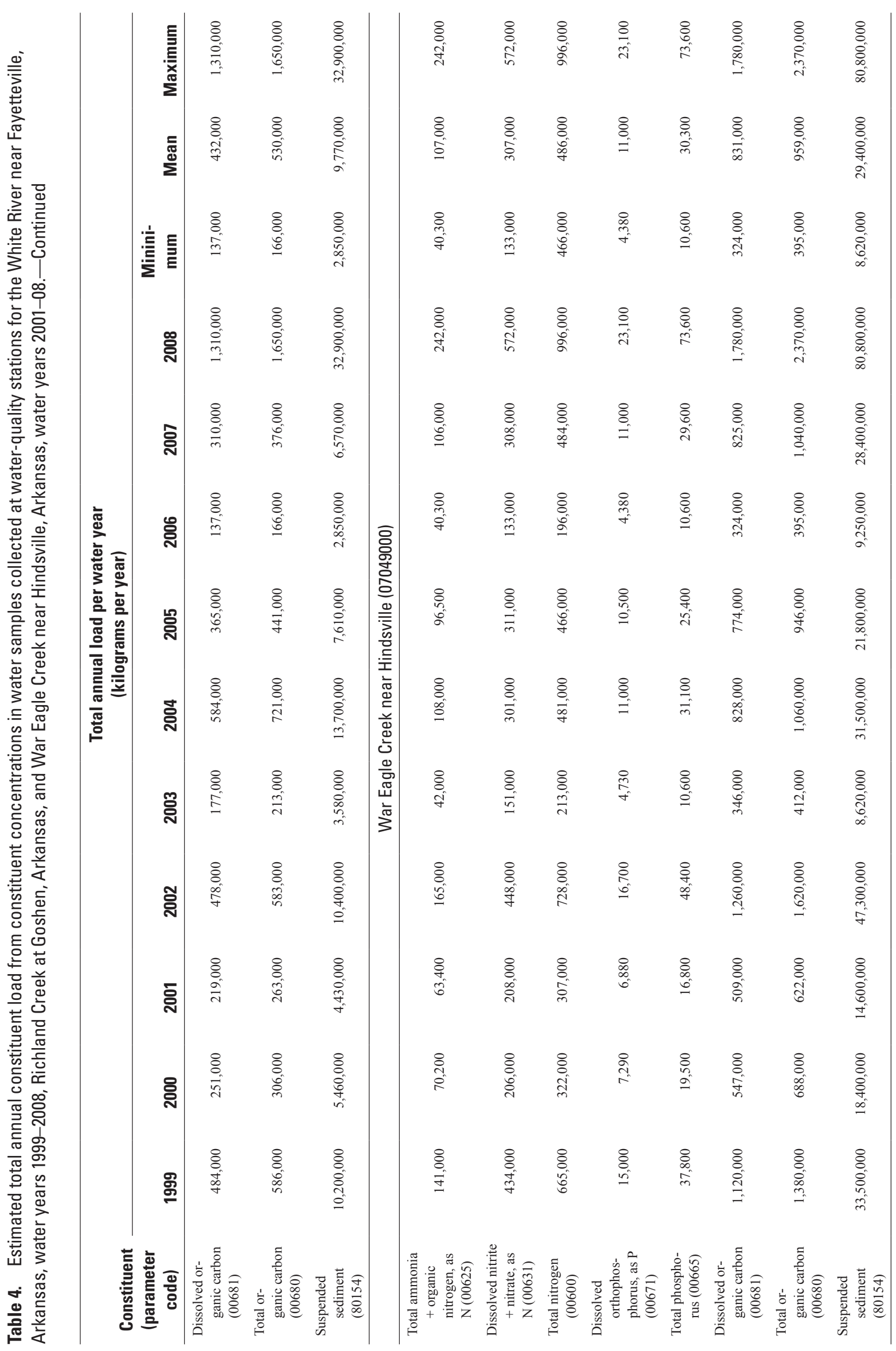


Table 5. Estimated mean annual constituent loads and yield estimated from constituent concentrations in water samples collected at water-quality stations for the White River near Fayetteville, Arkansas, water years 1999-2008, Richland Creek at Goshen, Arkansas, and War Eagle Creek near Hindsville, Arkansas, water years 2001-08.

[km², square kilometer; $\mathrm{kg} / \mathrm{yr}$, kilograms per year; $\mathrm{kg} / \mathrm{yr} / \mathrm{km}^{2}$, kilogram per year per square kilometer; SEP, standard error of prediction]

\begin{tabular}{|c|c|c|c|c|}
\hline \multirow[b]{2}{*}{$\begin{array}{l}\text { Station name } \\
\text { (number) }\end{array}$} & \multirow{2}{*}{$\begin{array}{c}\text { Drainage } \\
\text { area } \\
\left(\mathbf{k m}^{2}\right)\end{array}$} & \multirow[b]{2}{*}{$\begin{array}{l}\text { Constituent } \\
\text { (parameter code) }\end{array}$} & \multicolumn{2}{|c|}{ Estimated mean annual } \\
\hline & & & $\begin{array}{c}\text { Total load } \\
\text { (+/- SEP) (kg/yr) }\end{array}$ & $\begin{array}{l}\text { Total yield } \\
\left(\mathrm{kg} / \mathrm{yr} / \mathrm{km}^{2}\right)\end{array}$ \\
\hline \multirow[t]{8}{*}{$\begin{array}{l}\text { White River near Fayetteville } \\
\qquad(07048600)\end{array}$} & 1,040 & $\begin{array}{l}\text { Total ammonia + organic nitrogen, as } \mathrm{N} \\
\quad(00625)\end{array}$ & $294,000(219)$ & 283 \\
\hline & & Dissolved nitrite + nitrate, as N (00631) & $273,000(124)$ & 262 \\
\hline & & Total nitrogen $(00600)$ & $593,000(155)$ & 570 \\
\hline & & Dissolved orthophosphorus, as P (00671) & $10,300(16)$ & 10 \\
\hline & & Total phosphorus (00665) & $73,200(99)$ & 70 \\
\hline & & Dissolved organic carbon (00681) & $1,390,000(499)$ & 1,340 \\
\hline & & Total organic carbon $(00680)$ & $2,000,000(913)$ & 1,920 \\
\hline & & Suspended sediment (80154) & $68,500,000(59,600)$ & 65,900 \\
\hline \multirow[t]{8}{*}{$\begin{array}{l}\text { Richland Creek at Goshen } \\
\qquad(07048800)\end{array}$} & 357 & $\begin{array}{l}\text { Total ammonia + organic nitrogen, as } \mathrm{N} \\
\quad(00625)\end{array}$ & $56,300(63)$ & 158 \\
\hline & & Dissolved nitrite + nitrate, as N (00631) & $230,000(301)$ & 644 \\
\hline & & Total nitrogen $(00600)$ & $218,000(120)$ & 611 \\
\hline & & Dissolved orthophosphorus, as P (00671) & $2,210(4)$ & 6 \\
\hline & & Total phosphorus (00665) & $9,290(24)$ & 26 \\
\hline & & Dissolved organic carbon (00681) & $432,000(218)$ & 1,210 \\
\hline & & Total organic carbon $(00680)$ & $530,000(295)$ & 1,480 \\
\hline & & Suspended sediment (80154) & $9,770,000(12,000)$ & 27,400 \\
\hline \multirow[t]{8}{*}{$\begin{array}{l}\text { War Eagle Creek near Hindsville } \\
\qquad(07049000)\end{array}$} & 681 & $\begin{array}{l}\text { Total ammonia + organic nitrogen, as } \mathrm{N} \\
\quad(00625)\end{array}$ & $107,000(103)$ & 157 \\
\hline & & Dissolved nitrite + nitrate, as N (00631) & $307,000(90)$ & 451 \\
\hline & & Total nitrogen $(00600)$ & $486,000(125)$ & 714 \\
\hline & & Dissolved orthophosphorus, as P (00671) & $11,000(10)$ & 16 \\
\hline & & Total phosphorus (00665) & $30,300(23)$ & 44 \\
\hline & & Dissolved organic carbon (00681) & $831,000(385)$ & 1,220 \\
\hline & & Total organic carbon $(00680)$ & $959,000(514)$ & 1,410 \\
\hline & & Suspended sediment (80154) & $29,400,000(36,800)$ & 43,200 \\
\hline
\end{tabular}

${ }^{1}$ Calculated by S-LOADEST and are statistics of all data in the 10 -year period. 
Table 6. Estimated mean annual constituent loads, mean annual streamflows, and mean flow-weighted constituent concentrations at water-quality stations for the White River near Fayetteville, Arkansas, water years 1999-2008, Richland Creek at Goshen, Arkansas, and War Eagle Creek near Hindsville, Arkansas, water years 2001-08.

[kg/yr, kilogram per year; $\mathrm{ft}^{3} / \mathrm{s}$, cubic foot per second; mg/L, milligram per liter; $\mathrm{N}$, nitrogen; $\mathrm{P}$, phosphorus]

\begin{tabular}{|c|c|c|c|}
\hline \multirow[b]{2}{*}{$\begin{array}{l}\text { Station name } \\
\text { (number) }\end{array}$} & \multirow[b]{2}{*}{$\begin{array}{c}\text { Constituent } \\
\text { (parameter code) }\end{array}$} & \multicolumn{2}{|c|}{ Estimated mean annual } \\
\hline & & $\begin{array}{l}\text { Load } \\
(\mathrm{kg} / \mathrm{yr})\end{array}$ & $\begin{array}{c}\text { Flow-weighted } \\
\text { concentration } \\
\text { (mg/L) }\end{array}$ \\
\hline \multirow[t]{8}{*}{$\begin{array}{l}\text { White River near Fayetteville } \\
\qquad(07048600)\end{array}$} & Total ammonia + organic nitrogen, as N (00625) & 294,000 & 0.61 \\
\hline & Dissolved nitrite + nitrate, as N (00631) & 273,000 & 0.57 \\
\hline & Total nitrogen $(00600)$ & 593,000 & 1.23 \\
\hline & Dissolved orthophosphorus, as P (00671) & 10,300 & 0.02 \\
\hline & Total phosphorus (00665) & 73,200 & 0.15 \\
\hline & Dissolved organic carbon (00681) & $1,390,000$ & 2.94 \\
\hline & Total organic carbon $(00680)$ & $2,000,000$ & 4.19 \\
\hline & Suspended sediment (80154) & $68,500,000$ & 136 \\
\hline \multirow[t]{8}{*}{$\begin{array}{l}\text { Richland Creek at Goshen } \\
\quad(07048800)\end{array}$} & Total ammonia + organic nitrogen, as $\mathrm{N}(00625)$ & 56,300 & 0.35 \\
\hline & Dissolved nitrite + nitrate, as N (00631) & 230,000 & 1.42 \\
\hline & Total nitrogen $(00600)$ & 218,000 & 1.35 \\
\hline & Dissolved orthophosphorus, as P (00671) & 2,210 & 0.014 \\
\hline & Total phosphorus (00665) & 9,290 & 0.06 \\
\hline & Dissolved organic carbon $(00681)$ & 432,000 & 2.69 \\
\hline & Total organic carbon $(00680)$ & 530,000 & 3.28 \\
\hline & Suspended sediment (80154) & $9,770,000$ & 58.4 \\
\hline \multirow[t]{8}{*}{$\begin{array}{l}\text { War Eagle Creek near Hindsville } \\
\qquad(07049000)\end{array}$} & Total ammonia + organic nitrogen, as N $(00625)$ & 107,000 & 0.39 \\
\hline & Dissolved nitrite + nitrate, as N (00631) & 307,000 & 1.17 \\
\hline & Total nitrogen $(00600)$ & 486,000 & 1.81 \\
\hline & Dissolved orthophosphorus, as P (00671) & 11,000 & 0.04 \\
\hline & Total phosphorus (00665) & 30,300 & 0.11 \\
\hline & Dissolved organic carbon (00681) & 831,000 & 3.07 \\
\hline & Total organic carbon $(00680)$ & 959,000 & 3.84 \\
\hline & Suspended sediment (80154) & $29,400,000$ & 102 \\
\hline
\end{tabular}


and mean yield was $70 \mathrm{~kg} / \mathrm{yr} / \mathrm{km}^{2}$ (table 5). Estimated mean annual flow-weighted concentration was $0.15 \mathrm{mg} / \mathrm{L}$ (table 6).

\section{Dissolved Organic Carbon}

Dissolved organic carbon (DOC) concentrations for White River near Fayetteville ranged from 0.8 to $10.9 \mathrm{mg} / \mathrm{L}$ with a mean concentration of $2.8 \mathrm{mg} / \mathrm{L}$ (table 3 ). There was little relation between concentrations and streamflow (fig. 3). Loads were estimated as a function of streamflow ( $2=$ 0.94; table 2). These estimated loads were then compared to instantaneous measured load with a slope of 0.90 (fig. 4). For DOC, the 10-year mean load was 1,390,000 kg/yr (table 4) and mean yield was $1,340 \mathrm{~kg} / \mathrm{yr} / \mathrm{km} 2$ (table 5). Estimated mean annual flow-weighted concentration was $2.94 \mathrm{mg} / \mathrm{L}$ (table 6).

\section{Total Organic Carbon}

Total organic carbon (TOC) concentrations for White River near Fayetteville ranged from 0.7 to $19.5 \mathrm{mg} / \mathrm{L}$ with a mean concentration of $3.6 \mathrm{mg} / \mathrm{L}$ (table 3 ). There was a slight relation between concentration and streamflow (fig. 3). Loads were estimated as a function of streamflow ( $R 2=0.93$; table 2). These estimated loads were then compared to instantaneous measured load with a slope of 0.89 (fig. 4). For TOC, the 10-year mean load was 2,000,000 kg/yr (table 4) and mean yield was $1,920 \mathrm{~kg} / \mathrm{yr} / \mathrm{km} 2$ (table 5). Estimated mean annual flow-weighted concentration was $4.19 \mathrm{mg} / \mathrm{L}$ (table 6).

\section{Suspended Sediment}

Suspended sediment concentrations for White River near Fayetteville ranged from 2 to $950 \mathrm{mg} / \mathrm{L}$ with a mean concentration of $97 \mathrm{mg} / \mathrm{L}$ (table 3). Concentrations tended to increase with an increase in streamflow (fig. 3). Loads were estimated as a function of streamflow ( $R 2=0.94$; table 2$)$. These estimated loads were then compared to instantaneous measured load with a slope of 0.88 (fig. 4). For suspended sediment, the 10 -year mean load was $68,500,000 \mathrm{~kg} / \mathrm{yr}$ (table 4) and mean yield was $65,900 \mathrm{~kg} / \mathrm{yr} / \mathrm{km} 2$ (table 5). Estimated mean annual flow-weighted concentration was $136 \mathrm{mg} / \mathrm{L}$ (table 6).

\section{Constituent Concentrations, Loads, and Yields for Richland Creek, a Tributary to Beaver Lake, at Goshen}

\section{Total Ammonia plus Organic Nitrogen}

Total ammonia plus organic nitrogen concentrations for Richland Creek at Goshen ranged from less than 0.05 to $1.6 \mathrm{mg} / \mathrm{L}$ as $\mathrm{N}$ with a mean concentration of $0.29 \mathrm{mg} / \mathrm{L}$ as N (table 3). Concentrations tended to increase with increasing streamflow (fig. 5). Loads were estimated as a function of streamflow $\left(\mathrm{R}^{2}=0.97\right.$; table 2$)$. These estimated loads were then compared to instantaneous measured load with a slope of 0.79 (fig. 6). For total ammonia plus organic nitrogen as $\mathrm{N}$, the 10 -year mean load was $56,300 \mathrm{~kg} / \mathrm{yr}$ as $\mathrm{N}$ (table 4) and mean yield was $158 \mathrm{~kg} / \mathrm{yr} / \mathrm{km}^{2}$ as $\mathrm{N}$ (table 5). Estimated mean annual flow-weighted concentration was $0.35 \mathrm{mg} / \mathrm{L}$ as N (table 6).

\section{Dissolved Nitrite plus Nitrate Nitrogen}

Dissolved nitrite plus nitrate concentrations for Richland Creek at Goshen ranged from 0.01 (estimated) to $3.9 \mathrm{mg} / \mathrm{L}$ as $\mathrm{N}$ with a mean concentration of $0.850 \mathrm{mg} / \mathrm{L}$ as $\mathrm{N}$ (table 3 ). Concentrations tended to increase with increasing streamflow (fig. 5). Loads were estimated as a function of streamflow $\left(\mathrm{R}^{2}\right.$ $=0.96$; table 2 ). These estimated loads were then compared to instantaneous measured load with a slope of 0.68 (fig. 6). For dissolved nitrite plus nitrate, the 10 -year mean load was $230,000 \mathrm{~kg} / \mathrm{yr}$ as $\mathrm{N}$ (table 4) and mean yield was $644 \mathrm{~kg} / \mathrm{yr} /$ $\mathrm{km}^{2}$ as $\mathrm{N}$ (table 5). Estimated mean annual flow-weighted concentration was $1.42 \mathrm{mg} / \mathrm{L}$ as N (table 6).

\section{Total Nitrogen}

Total nitrogen concentrations for Richland Creek at Goshen ranged from 0.20 to $4.1 \mathrm{mg} / \mathrm{L}$ with a mean concentration of $1.2 \mathrm{mg} / \mathrm{L}$ (table 3 ). Concentrations tended to increase with increasing streamflow (fig. 5). Loads were estimated as a function of streamflow $\left(\mathrm{R}^{2}=0.99\right.$; table 2$)$. These estimated 

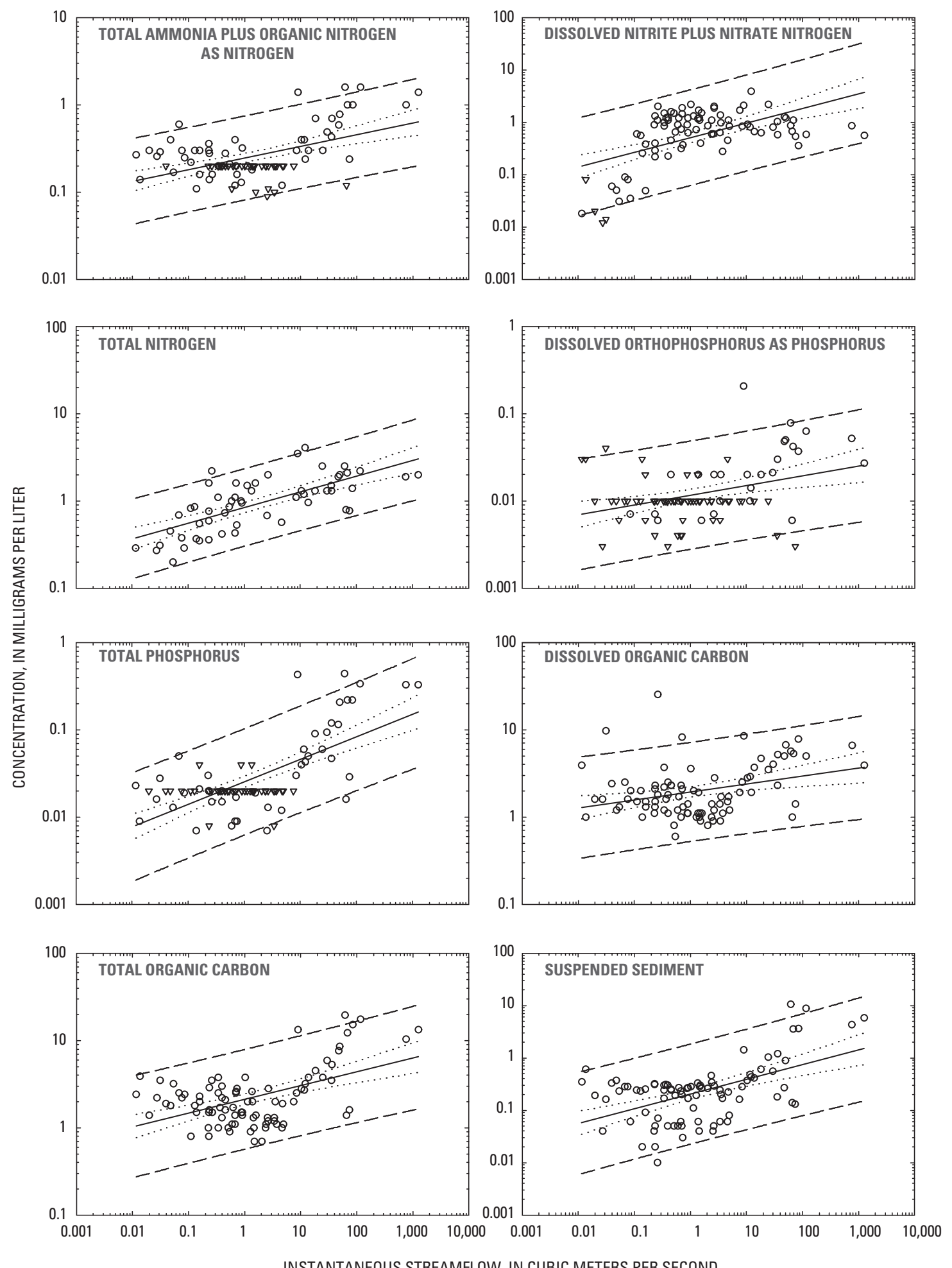

INSTANTANEOUS STREAMFLOW, IN CUBIC METERS PER SECOND

\section{EXPLANATION}

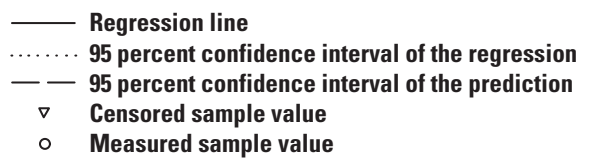

Figure 5. Relation between nutrient and sediment concentraitons and instantaneous streamflow for samples collected at Richland Creek at Goshen, Arkansas, water years 2001-08. 

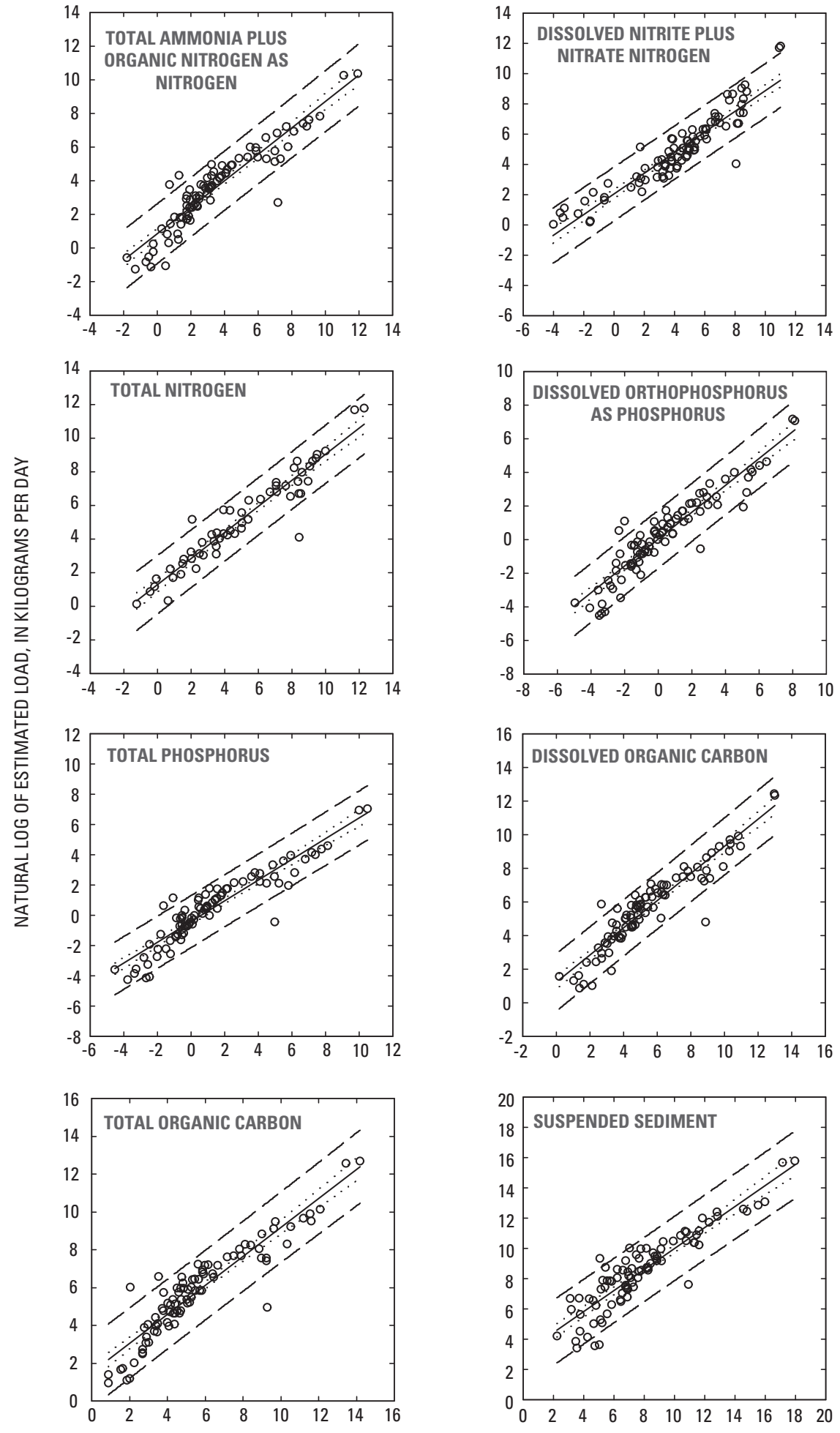

NATURAL LOG OF INSTANTANEOUS MEASURED LOAD,

IN KILOGRAMS PER DAY

EXPLANATION

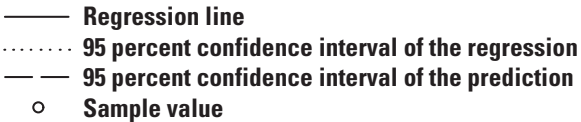

Figure 6. Relation between natural log of instantaneous measured load and natural log of estimated load for samples collected at Richland Creek at Goshen, Arkansas, water years 2001-08. 
loads were then compared to instantaneous measured load with a slope of 0.78 (fig. 6). For total nitrogen, the 10 -year mean load was $218,000 \mathrm{~kg} / \mathrm{yr}$ (table 4 ) and mean yield was $611 \mathrm{~kg} / \mathrm{yr} / \mathrm{km}^{2}$ (table 5). Estimated mean annual flowweighted concentration was $1.35 \mathrm{mg} / \mathrm{L}$ (table 6).

\section{Dissolved Orthophosphorus}

Dissolved orthophosphorus concentrations for Richland Creek at Goshen ranged from less than 0.003 to $0.207 \mathrm{mg} / \mathrm{L}$ as $\mathrm{P}$ with a mean concentration of $0.017 \mathrm{mg} / \mathrm{L}$ as $\mathrm{P}$ (table 3 ). Concentrations tended to increase slightly with increasing streamflow (fig. 5). Loads were estimated as a function of streamflow $\left(\mathrm{R}^{2}=0.94\right.$; table 2$)$. These estimated loads were then compared to instantaneous measured load with a slope of 0.80 (fig. 6). For dissolved orthophosphorus, the 10-year mean load was $2,210 \mathrm{~kg} / \mathrm{yr}$ as $\mathrm{P}$ (table 4 ) and mean yield was $6 \mathrm{~kg} / \mathrm{yr} / \mathrm{km}^{2}$ as P (table 5). Estimated mean annual flowweighted concentration was $0.014 \mathrm{mg} / \mathrm{L}$ as $\mathrm{P}$ (table 6).

\section{Total Phosphorus}

Total phosphorus concentrations for Richland Creek at Goshen ranged from 0.007 to $0.440 \mathrm{mg} / \mathrm{L}$ with a mean concentration of $0.044 \mathrm{mg} / \mathrm{L}$ (table 3 ). Concentrations tended to increase with increasing streamflow (fig. 5). Loads were estimated as a function of streamflow $\left(\mathrm{R}^{2}=0.94\right.$; table 2$)$. These estimated loads were then compared to instantaneous measured load with a slope of 0.68 (fig. 6). For total phosphorus, the 10-year mean load was 9,290 kg/yr (table 4) and mean yield was $26 \mathrm{~kg} / \mathrm{yr} / \mathrm{km}^{2}$ (table 5). Estimated mean annual flow-weighted concentration was $0.06 \mathrm{mg} / \mathrm{L}$ (table 6).

\section{Dissolved Organic Carbon}

DOC concentrations for Richland Creek at Goshen ranged from 0.6 to $25.4 \mathrm{mg} / \mathrm{L}$ with a mean concentration of $2.56 \mathrm{mg} / \mathrm{L}$ (table 3 ). Concentrations tended to increase slightly with increases in stream streamflow (fig. 5). Loads were estimated as a function of streamflow $\left(\mathrm{R}^{2}=0.99\right.$; table $2)$. These estimated loads were then compared to instantaneous measured load with a slope of 0.81 (fig. 6). For DOC, the 10 -year mean load was $432,000 \mathrm{~kg} / \mathrm{yr}$ (table 4) and mean yield was $1,210 \mathrm{~kg} / \mathrm{yr} / \mathrm{km}^{2}$ (table 5). Estimated mean annual flow-weighted concentration was $2.69 \mathrm{mg} / \mathrm{L}$ (table 6).

\section{Total Organic Carbon}

TOC concentrations for Richland Creek at Goshen ranged from 0.7 to $19.5 \mathrm{mg} / \mathrm{L}$ with a mean concentration of $3.00 \mathrm{mg} / \mathrm{L}$ (table 3). Concentrations tended to increase with increasing stream streamflow (fig. 5). Loads were estimated as a function of streamflow $\left(\mathrm{R}^{2}=0.99\right.$; table 2$)$. These estimated loads were then compared to instantaneous measured load with a slope of
0.77 (fig. 6). For TOC, the 10-year mean load was 530,000 $\mathrm{kg} / \mathrm{yr}$ (table 4) and mean yield was $1,480 \mathrm{~kg} / \mathrm{yr} / \mathrm{km}^{2}$ (table 5). Estimated mean annual flow-weighted concentration was 3.28 $\mathrm{mg} / \mathrm{L}$ (table 6).

\section{Suspended Sediment}

Suspended sediment concentrations for Richland Creek at Goshen ranged from 1 to $1,050 \mathrm{mg} / \mathrm{L}$ with a mean concentration of $58 \mathrm{mg} / \mathrm{L}$ (table 3 ). Concentrations tended to increase with increasing streamflow (fig. 5). Loads were estimated as a function of streamflow $\left(\mathrm{R}^{2}=0.97\right.$; table 2$)$. These estimated loads were then compared to instantaneous measured load with a slope of 0.70 (fig. 6). For suspended sediment, the 10 -year mean load was $9,770,000 \mathrm{~kg} / \mathrm{yr}$ (table 4) and mean yield was $27,400 \mathrm{~kg} / \mathrm{yr} / \mathrm{km}^{2}$ (table 5). Estimated mean annual flow-weighted concentration was $58.4 \mathrm{mg} / \mathrm{L}$ (table 6).

\section{Constituent Concentrations, Loads, and Yields for War Eagle Creek, a Tributary to Beaver Lake, near Hindsville}

\section{Total Ammonia plus Organic Nitrogen}

Total ammonia plus organic nitrogen concentrations for War Eagle Creek near Hindsville ranged from less than 0.05 to $2.3 \mathrm{mg} / \mathrm{L}$ as $\mathrm{N}$ with a mean concentration of $0.28 \mathrm{mg} / \mathrm{L}$ as $\mathrm{N}$ (table 3). Concentrations tended to increase with increasing streamflow (fig. 7). Loads were estimated as a function of streamflow $\left(\mathrm{R}^{2}=0.82\right.$; table 2$)$. These estimated loads were then compared to instantaneous measured load with a slope of 0.93 (fig. 8). For total ammonia plus organic nitrogen, the 10 -year mean load was $107,000 \mathrm{~kg} / \mathrm{yr}$ as $\mathrm{N}$ (table 4) and mean yield was $157 \mathrm{~kg} / \mathrm{yr} / \mathrm{km}^{2}$ as $\mathrm{N}$ (table 5). Estimated mean annual flow-weighted concentration was $0.39 \mathrm{mg} / \mathrm{L}$ as $\mathrm{N}$ (table 6).

\section{Dissolved Nitrite plus Nitrate Nitrogen}

Dissolved nitrite plus nitrate concentrations for War Eagle Creek near Hindsville ranged from 0.257 to $2.36 \mathrm{mg} / \mathrm{L}$ as $\mathrm{N}$ with a mean concentration of $1.16 \mathrm{mg} / \mathrm{L}$ as $\mathrm{N}$ (table 3 ). There was no relation between concentrations and changes in streamflow (fig. 7). Loads were estimated as a function of streamflow $\left(\mathrm{R}^{2}=0.94\right.$; table 2$)$. These estimated loads were then compared to instantaneous measured load with a slope of 0.92 (fig. 8). For dissolved nitrate plus nitrite concentrations, the 10 -year mean load was $307,000 \mathrm{~kg} / \mathrm{yr}$ as $\mathrm{N}$ (table 4) and mean yield was $451 \mathrm{~kg} / \mathrm{yr} / \mathrm{km}^{2}$ as $\mathrm{N}$ (table 5). Estimated mean annual flow-weighted concentration was $1.17 \mathrm{mg} / \mathrm{L}$ as $\mathrm{N}$ (table 6). 

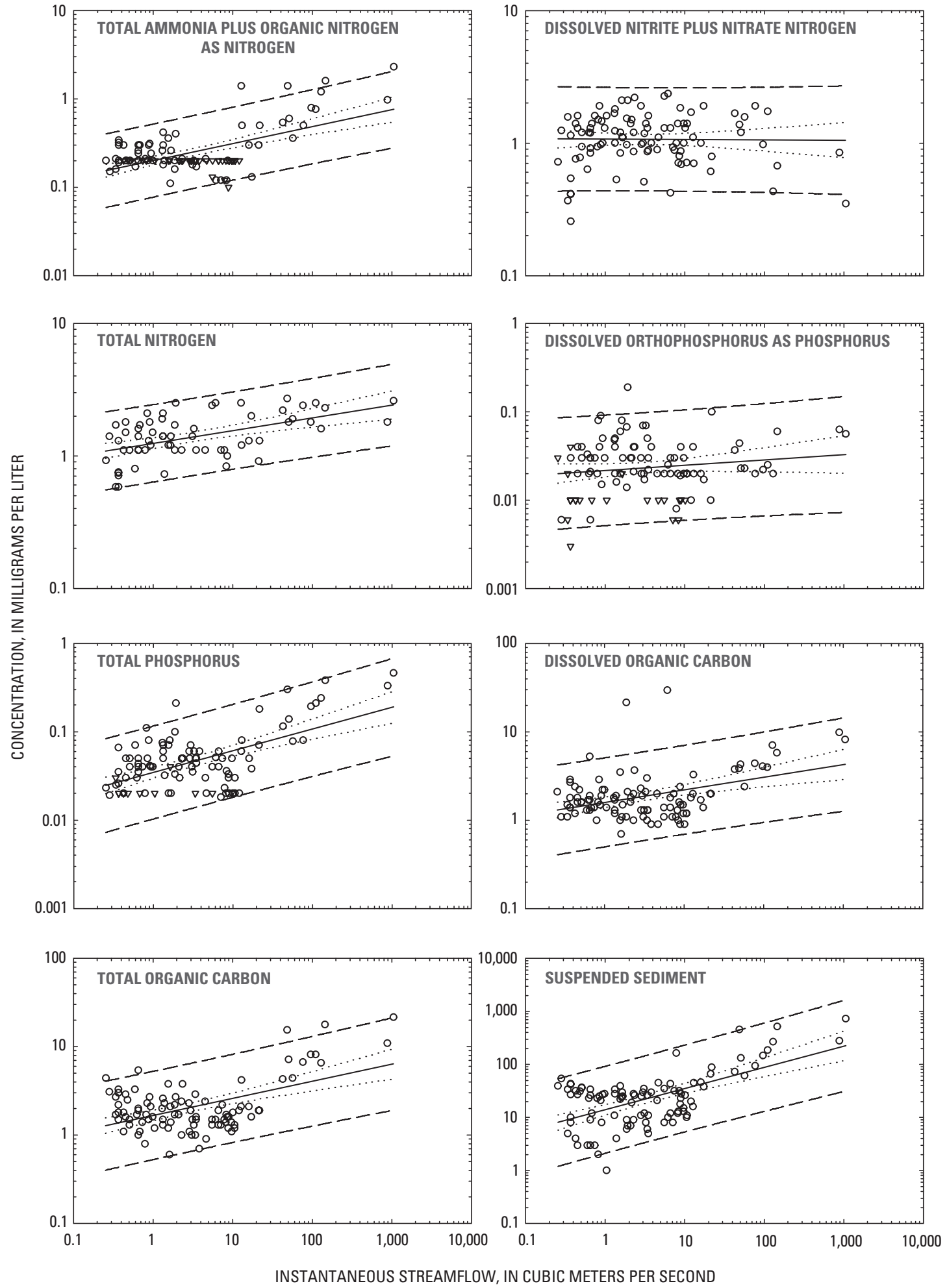

\section{EXPLANATION}

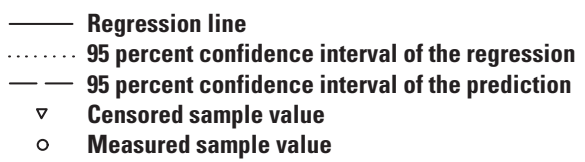

Figure 7. Relation between nutrient and sediment concentrations and instantaneous streamflow volume for samples collected at War Eagle Creek near Hindsville, Arkansas, water years 2001-08. 

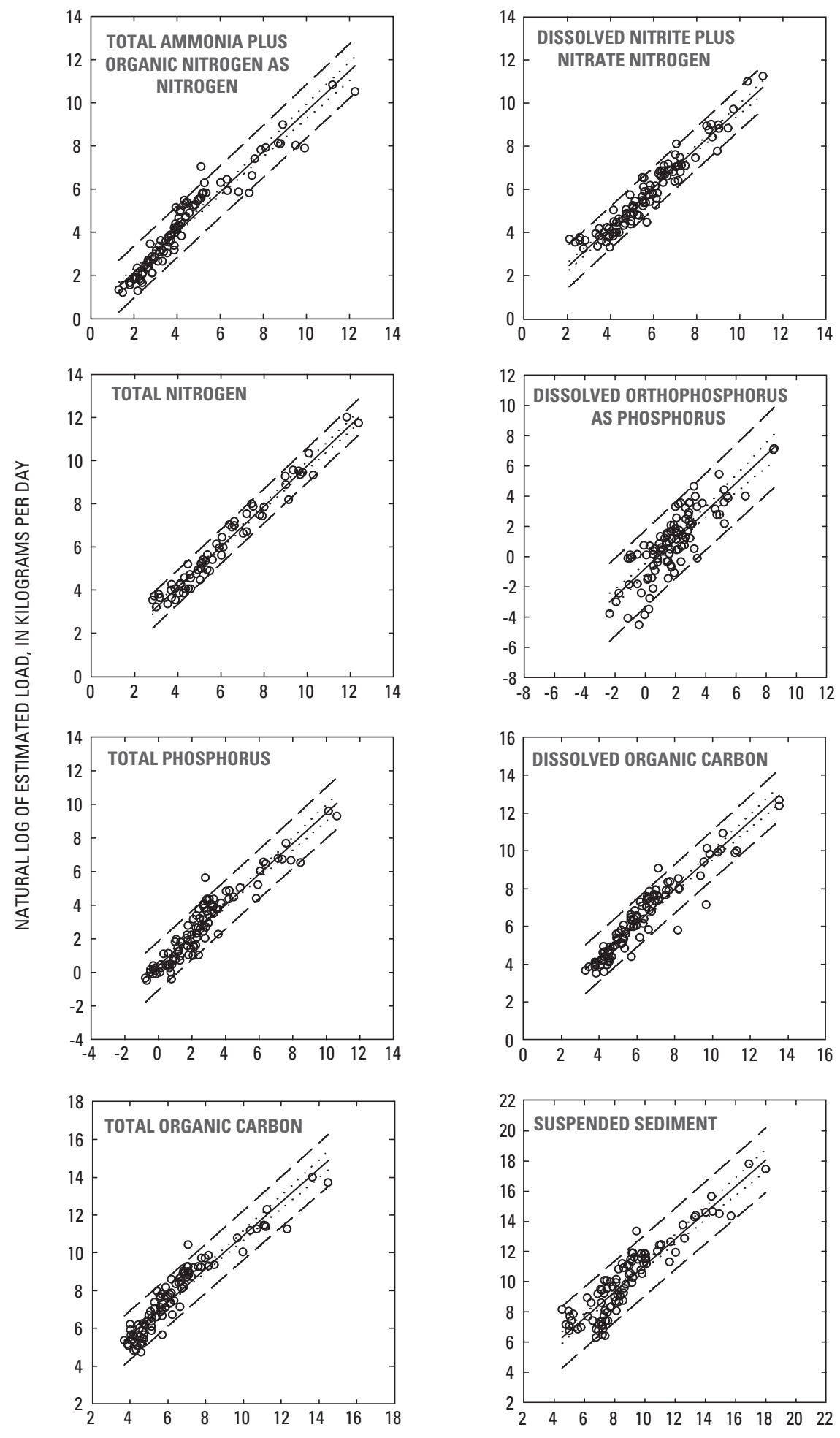

NATURAL LOG OF INSTANTANEOUS MEASURED LOAD,

IN KILOGRAMS PER DAY

EXPLANATION

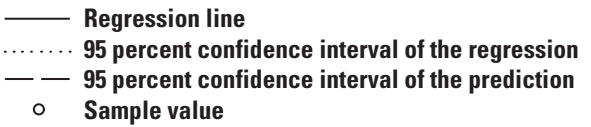

Figure 8. Relation between natural log of instantaneous measured load and natural log of estimated load for samples collected at War Eagle Creek near Hindsville, Arkansas, water years 2001-08. 


\section{Total Nitrogen}

Total nitrogen concentrations for War Eagle Creek near Hindsville ranged from 0.58 to $2.7 \mathrm{mg} / \mathrm{L}$ with a mean concentration of $1.5 \mathrm{mg} / \mathrm{L}$ (table 3 ). Concentrations tended to increase slightly with increasing streamflow (fig. 7). Loads were estimated as a function of streamflow $\left(\mathrm{R}^{2}=0.98\right.$; table $2)$. These estimated loads were then compared to instantaneous measured load with a slope of 0.94 (fig. 8). For total nitrogen, the 10-year mean load was 486,000 kg/yr (table 4) and mean yield was $714 \mathrm{~kg} / \mathrm{yr} / \mathrm{km}^{2}$ (table 5). Estimated mean annual flow-weighted concentration was $1.81 \mathrm{mg} / \mathrm{L}$ (table 6).

\section{Dissolved Orthophosphorus}

Dissolved orthophosphorus concentrations for War Eagle Creek near Hindsville ranged from less than 0.003 to 0.19 $\mathrm{mg} / \mathrm{L}$ as $\mathrm{P}$ with a mean concentration of $0.029 \mathrm{mg} / \mathrm{L}$ as $\mathrm{P}$ (table $3)$. Concentrations tended to increase slightly with increasing streamflow (fig. 7). Loads were estimated as a function of streamflow $\left(\mathrm{R}^{2}=0.79\right.$; table 2$)$. These estimated loads were then compared to instantaneous measured load with a slope of 0.94 (fig. 8). For dissolved orthophosphorus, the 10-year mean load was $11,000 \mathrm{~kg} / \mathrm{yr}$ as P (table 4 ) and mean yield was $16 \mathrm{~kg} / \mathrm{yr} / \mathrm{km}^{2}$ as P (table 5). Estimated mean annual flowweighted concentration was $0.04 \mathrm{mg} / \mathrm{L}$ as $\mathrm{P}$ (table 6).

\section{Total Phosphorus}

Total phosphorus concentrations for War Eagle Creek near Hindsville ranged from 0.018 to $0.460 \mathrm{mg} / \mathrm{L}$ with a mean concentration of $0.064 \mathrm{mg} / \mathrm{L}$ (table 3 ). Concentrations tended to increase with increasing streamflow (fig. 7). Loads were estimated as a function of streamflow $\left(\mathrm{R}^{2}=0.89\right.$; table 2 ). These estimated loads were then compared to instantaneous measured load with a slope of 0.91 (fig. 8). For total phosphorus, the 10-year mean load was $30,300 \mathrm{~kg} / \mathrm{yr}$ (table 4) and mean yield was $44 \mathrm{~kg} / \mathrm{yr} / \mathrm{km}^{2}$ (table 5). Estimated mean annual flow-weighted concentration was $0.11 \mathrm{mg} / \mathrm{L}$ (table 6).

\section{Dissolved Organic Carbon}

DOC concentrations for War Eagle Creek near Hindsville ranged from 0.7 to $29.8 \mathrm{mg} / \mathrm{L}$ with a mean concentration of $2.6 \mathrm{mg} / \mathrm{L}$ (table 3 ). Concentrations tended to increase slightly with increases in streamflow (fig. 7). Loads were estimated as a function of streamflow $\left(\mathrm{R}^{2}=0.92\right.$; table 2$)$. These estimated loads were then compared to instantaneous measured load with a slope of 0.90 (fig. 8). For DOC, the 10-year mean load was $831,000 \mathrm{~kg} / \mathrm{yr}$ (table 4) and mean yield was $1,220 \mathrm{~kg} / \mathrm{yr} /$ $\mathrm{km}^{2}$ (table 5). Estimated mean annual flow-weighted concentration was $3.07 \mathrm{mg} / \mathrm{L}$ (table 6).

\section{Total Organic Carbon}

TOC concentrations for War Eagle Creek near Hindsville ranged from 0.6 to $21.6 \mathrm{mg} / \mathrm{L}$ with a mean concentration of 2.8 $\mathrm{mg} / \mathrm{L}$ (table 3). Concentrations tended to increase with increasing streamflow (fig. 7). Loads were estimated as a function of streamflow $\left(\mathrm{R}^{2}=0.93\right.$; table 2$)$. These estimated loads were then compared to instantaneous measured load with a slope of 0.88 (fig. 8). For TOC, the 10-year mean load was 959,000 $\mathrm{kg} / \mathrm{yr}$ (table 4) and mean yield was $1,410 \mathrm{~kg} / \mathrm{yr} / \mathrm{km}^{2}$ (table 5). Estimated mean annual flow-weighted concentration was 3.84 $\mathrm{mg} / \mathrm{L}$ (table 6).

\section{Suspended Sediment}

Suspended sediment concentrations for War Eagle Creek near Hindsville ranged from less than 0.5 to $727 \mathrm{mg} / \mathrm{L}$ with a mean concentration of $50 \mathrm{mg} / \mathrm{L}$ (table 3 ). Concentrations tended to increase with increasing streamflow (fig. 7). Loads were estimated as a function of streamflow $\left(\mathrm{R}^{2}=0.86\right.$; table $2)$. These estimated loads were then compared to instantaneous measured load with a slope of 0.87 (fig. 8). For suspended sediment, the 10-year mean load was 29,400,000 $\mathrm{kg} / \mathrm{yr}$ (table 4) and mean yield was 43,200 kg/yr/ $\mathrm{km}^{2}$ (table 5). Estimated mean annual flow-weighted concentration was 102 $\mathrm{mg} / \mathrm{L}$ (table 6).

\section{Tributary Water-Quality Comparison}

Constituent concentrations, loads, and yields varied with time among the three tributaries contributing to Beaver Lake. These variations can result from differences in precipitation, land use, contributions of nutrients from point sources, and variations in basin size. Overall, for the 10-year period, constituent loads followed streamflow trends resulting from yearly weather changes. Generally, during wetter years, increased runoff contributed to an increase in streamflow. Fluctuation in load values followed the annual streamflow patterns (figs. 9-11). Load and yield estimates varied yearly during the study period, water years 1999-2008, with the least nutrient and sediment loads and yields generally occurring in water year 2006, and the greatest occurring in water year 2008, a year with extreme floods near Beaver Lake (Funkhouser and Eng, 2009).

\section{Annual Flow-Weighted Concentrations}

Flow-weighted concentrations of most constituents were greater at the War Eagle Creek station than at the White River and Richland Creek stations. Of the three stations, flow-weighted concentrations of total nitrogen, dissolved orthophosphorus as P, DOC, and suspended sediment were greatest at the War Eagle Creek station (figs. 12 and 13). 

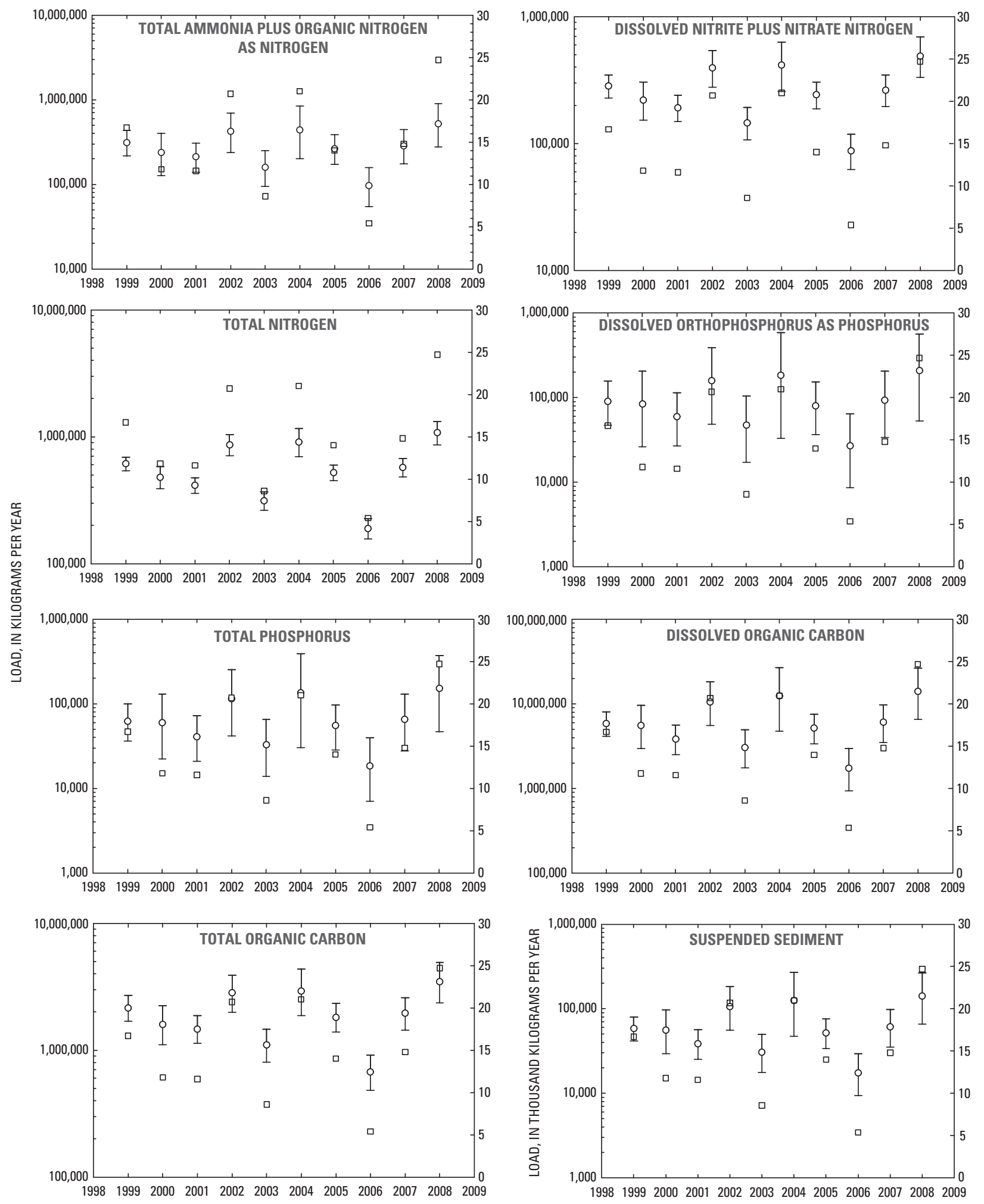

WATER YEAR

\section{EXPLANATION}

$\begin{array}{ll}\text { 을 } & \text { Load with } 95 \text { percent confidence whiskers } \\ \square & \text { Mean annual streamflow }\end{array}$

Figure 9. Time series of annual load and streamflow at White River near Fayetteville, Arkansas, water years 1999-2008. 

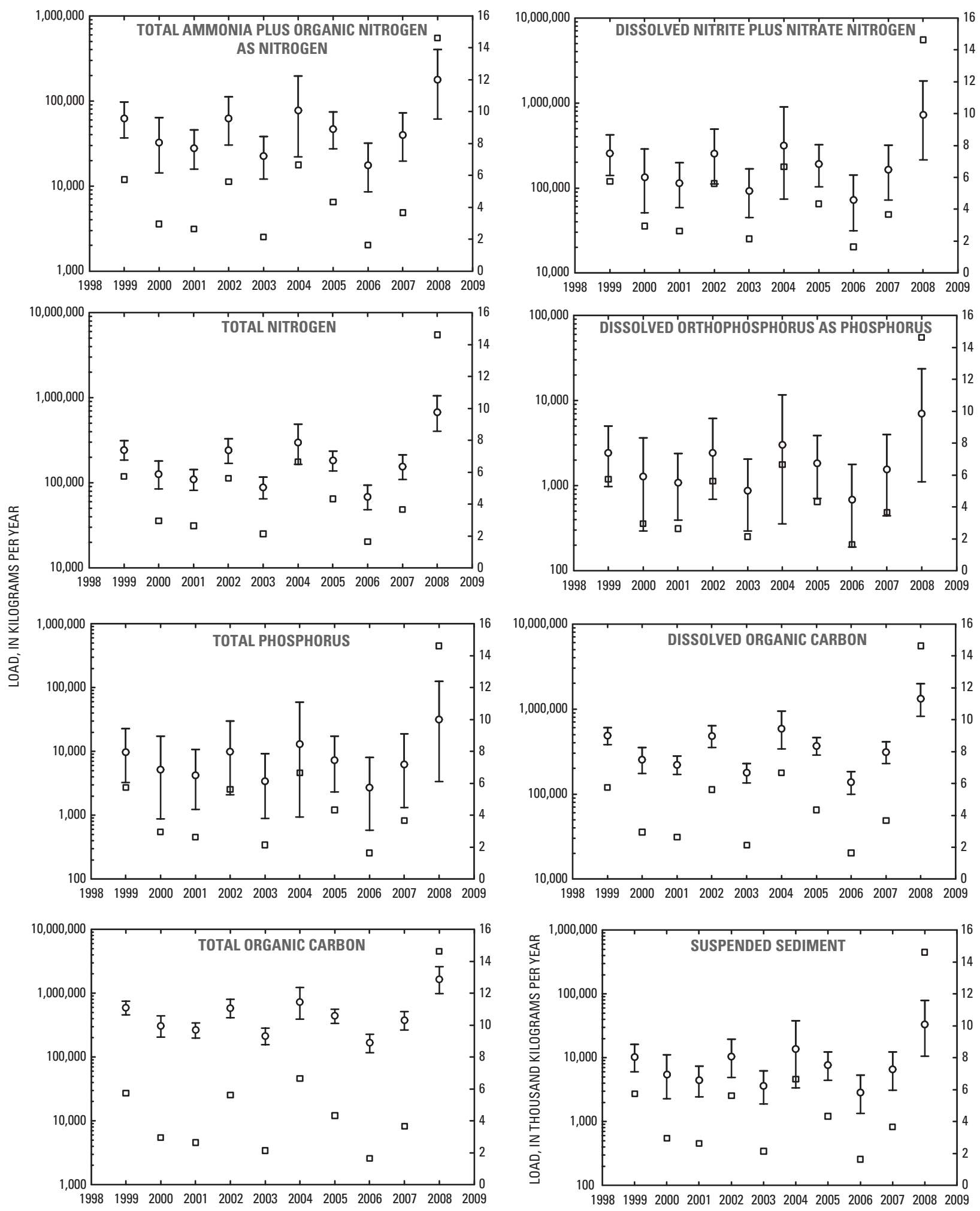

WATER YEAR

EXPLANATION

오 Load with 95 percent confidence whiskers

Mean annual streamflow

Figure 10. Time series of annual load and streamflow at Richland Creek at Goshen, Arkansas, water years 1999-2008. 

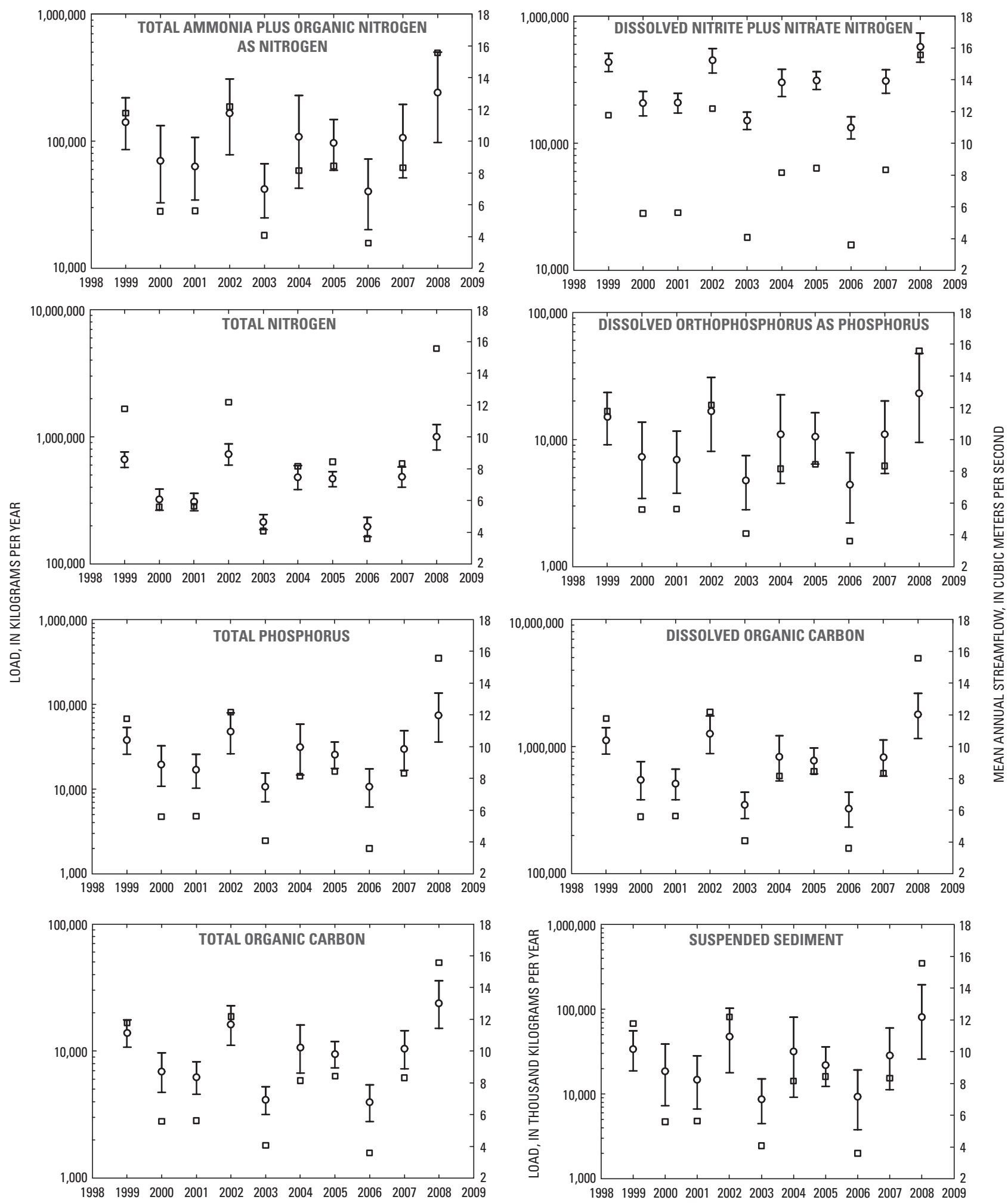

WATER YEAR

EXPLANATION

Load with 95 percent confidence whiskers

M Mean annual streamflow

Figure 11. Time series of annual load and streamflow at War Eagle Creek near Hindsville, Arkansas, water years 1999-2008. 

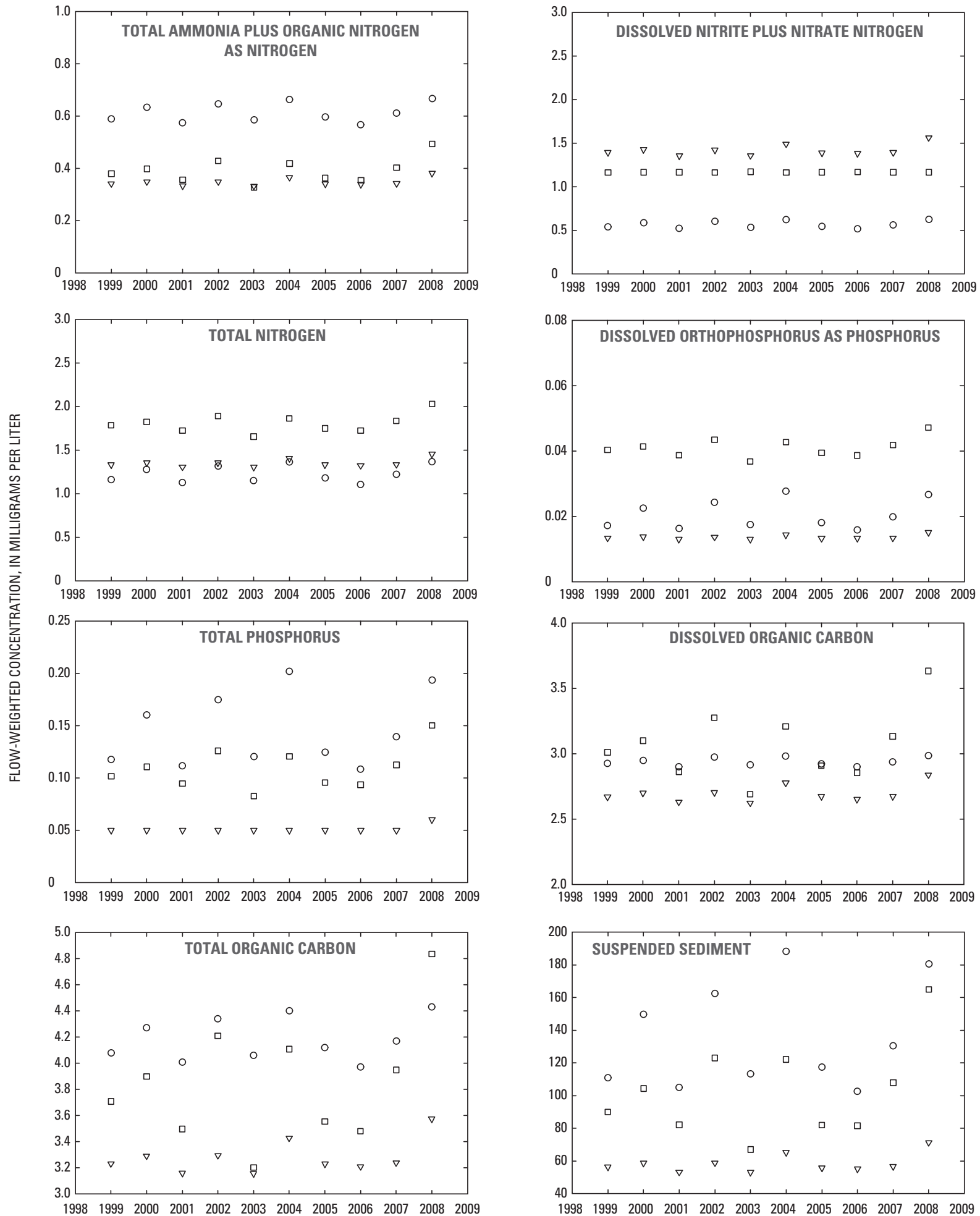

WATER YEAR

\section{EXPLANATION}

\footnotetext{
- White River near Fayetteville, Arkansas

$\nabla$ Richland Creek at Goshen, Arkansas

口 War Eagle Creek near Hindsville, Arkansas
}

Figure 12. Time series of annual flow-weighted concentrations for nutrients, organic carbon, and sediment at White River near Fayetteville, Richland Creek at Goshen, and War Eagle Creek near Hindsville, Arkansas, water years 1999-2008. 

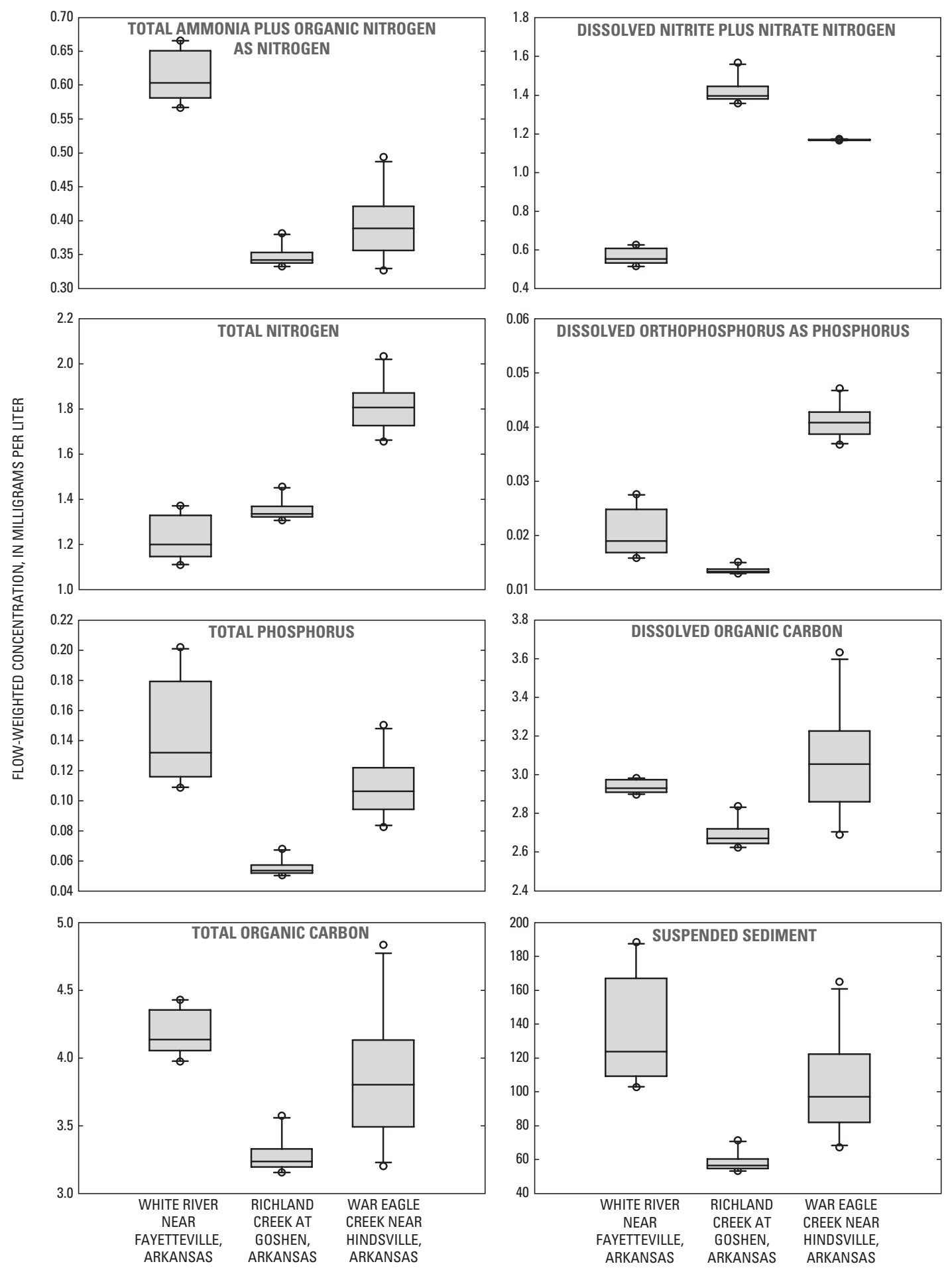

EXPLANATION

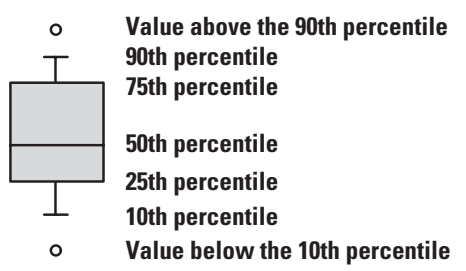

Figure 13. Distributions of annual nutrient, organic carbon, and sediment flow-weighted concentrations from water samples collected at White River near Fayetteville, Richland Creek at Goshen, and War Eagle Creek near Hindsville, Arkansas, water years 1999-2008. 
Flow-weighted concentrations of total ammonia plus organic nitrogen, total phosphorus, and TOC were greatest at the White River station. Flow-weighted concentrations of dissolved nitrite plus nitrate were greatest at the Richland Creek station.

\section{Annual Loads}

Loads of most constituents were greatest at the War Eagle Creek and White River stations (fig. 14, table 4). Load amounts do not represent the contribution of the constituent for the entire basin but only that part upstream from the station where the samples were collected. Of the three stations, loads of dissolved nitrite plus nitrate and dissolved orthophosphorus were greatest at the War Eagle Creek station. Loads of total ammonia plus organic nitrogen, total nitrogen, total phosphorus, DOC, TOC, and suspended sediment were greatest at the White River station. Loads were least for all constituents at the Richland Creek station.

\section{Annual Yields}

Yields of most constituents were greatest at the War Eagle Creek and White River stations (fig. 15, table 5). Yield amounts do not represent the contribution of the constituent for the entire basin but only that part upstream from the station where the samples were collected. Of the three stations, yields of total nitrogen and dissolved orthophosphorus were greatest at the War Eagle Creek station. Yields of total ammonia plus organic nitrogen, total phosphorus, DOC, TOC, and suspended sediment were greatest at the White River station. Yields at Richland Creek were least for all constituents except dissolved nitrite plus nitrate, which were greatest at Richland Creek.

\section{Summary}

Beaver Lake is a large, deep-storage reservoir used as the primary drinking-water supply for northwestern Arkansas and a primary watershed of concern for the State of Arkansas. Because of increased population growth and varying land use, information is needed to assess water quality, especially nutrient enrichment and sediment issues within the reservoir system. In 1999, streamflow-gaging stations at White River near Fayetteville (USGS station 07048600) and War Eagle Creek near Hindsville (USGS station 07049000) were converted from partial-record stations (supported by the USACE) to continuous-record stations, and a new streamflow-gaging station was established on Richland Creek at Goshen (USGS station 07048800), in cooperation with Beaver Water District.
Also, periodic water-quality samples were collected at the White River near Fayetteville station in cooperation with Arkansas Soil and Water Conservation Commission, now Arkansas Natural Resources Commission. In 2001, USGS in cooperation with Beaver Water District modified the White River near Fayetteville water-quality sampling and initiated water-quality sampling at both the Richland Creek and War Eagle Creek stations. Water-quality sampling has continued at all three stations to present. Water-quality samples collected during the study period represented different flow conditions (from low to high).

This report describes constituent loads, yields, and flow-weighted concentrations to Beaver Lake for White River, Richland Creek, and War Eagle Creek for the period 1999-2008 water years. Constituents include total ammonia plus organic nitrogen, dissolved nitrite plus nitrate nitrogen, total nitrogen, dissolved orthophosphorus (soluble reactive phosphorus), total phosphorus, dissolved organic carbon, total organic carbon, and suspended sediment.

The Beaver Lake study area comprises the lake with three main tributaries: White River, Richland Creek, and War Eagle Creek. Several smaller tributaries also flow into the reservoir. The basin has a drainage area of 2,968 $\mathrm{km}^{2}$ upstream from Beaver Lake Dam. The White River is the largest tributary followed by War Eagle Creek and Richland Creek. Combined, these three tributaries represent approximately 69 percent of the total drainage area of Beaver Lake (measured upstream from the measured streamflow-gaging stations).

Estimated mean annual constituent loads and standard deviations of the mean loads were calculated by S-LOADEST using all available data for each constituent for the 10-year period. Constituent yields for each of the three stations were calculated by dividing mean annual constituent load by the drainage area, in square kilometers. Flow-weighted concentrations for each of the three stations were calculated by dividing mean annual constituent loads by mean annual streamflow and multiplying by a conversion factor to adjust the units.

Constituent concentrations, loads, and yields varied with time and varied among the three tributaries contributing to Beaver Lake. These variations can result from differences in precipitation, land use, contributions of nutrients from point sources, and variations in basin size. Load and yield estimates varied yearly during the study period, water years 1999-2008, with the least nutrient and sediment load and yields generally occurring in water year 2006, and the greatest occurring in water year 2008, during a year with record amounts of precipitation. Flow-weighted concentrations of most constituents were greatest at the War Eagle Creek station than at the White River and Richland Creek stations. Loads and yields of most constituents were greatest at the War Eagle Creek and White River stations than at the Richland Creek station. 

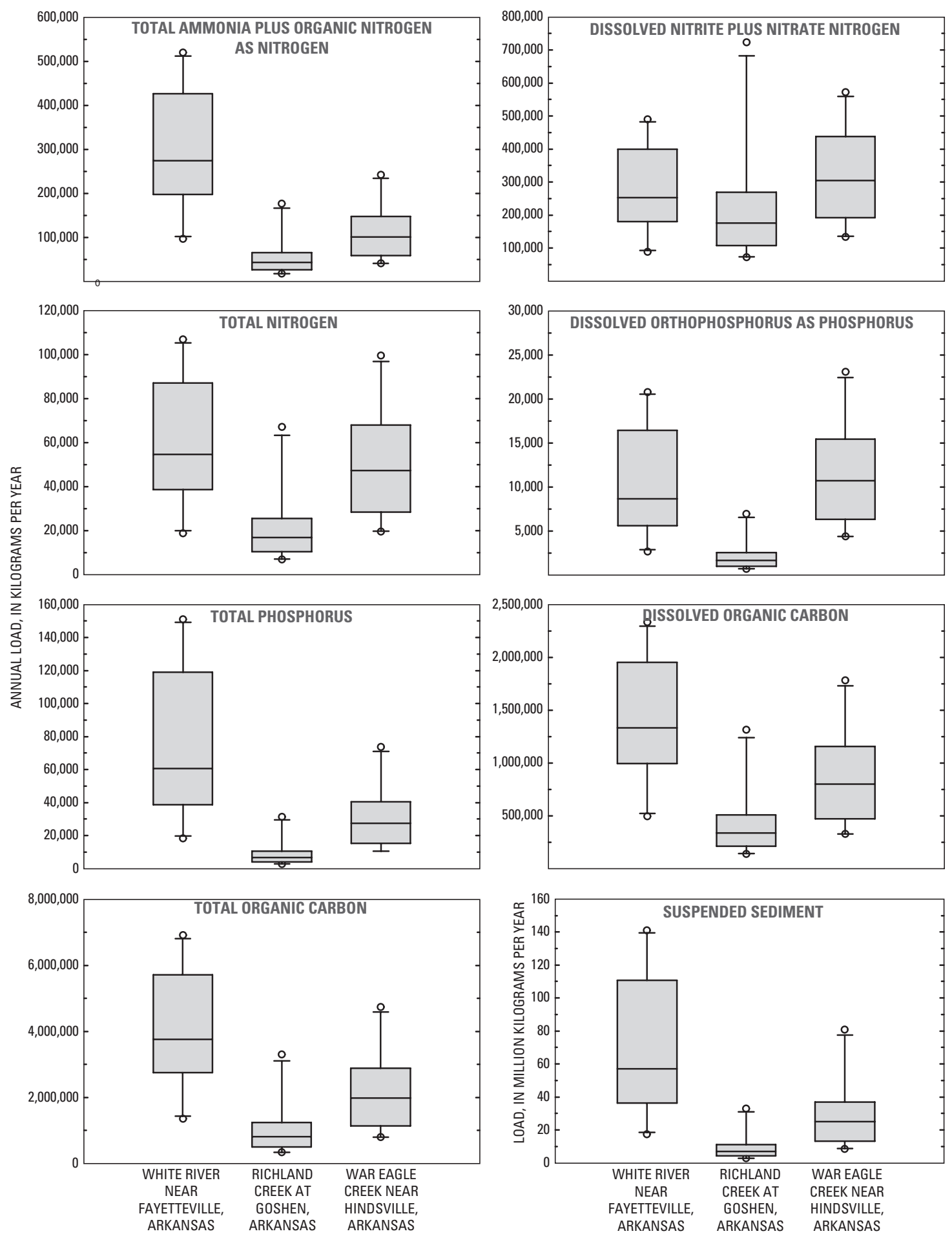

EXPLANATION

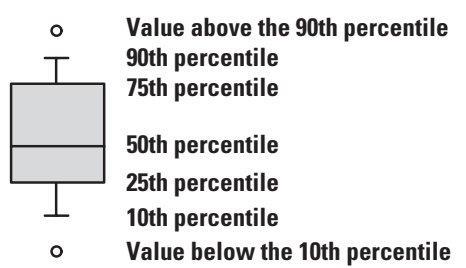

Figure 14. Distributions of annual nutrient, organic carbon, and sediment loads from water samples collected at White River near Fayetteville, Richland Creek at Goshen, and War Eagle Creek near Hindsville, Arkansas, water years 1999-2008. 

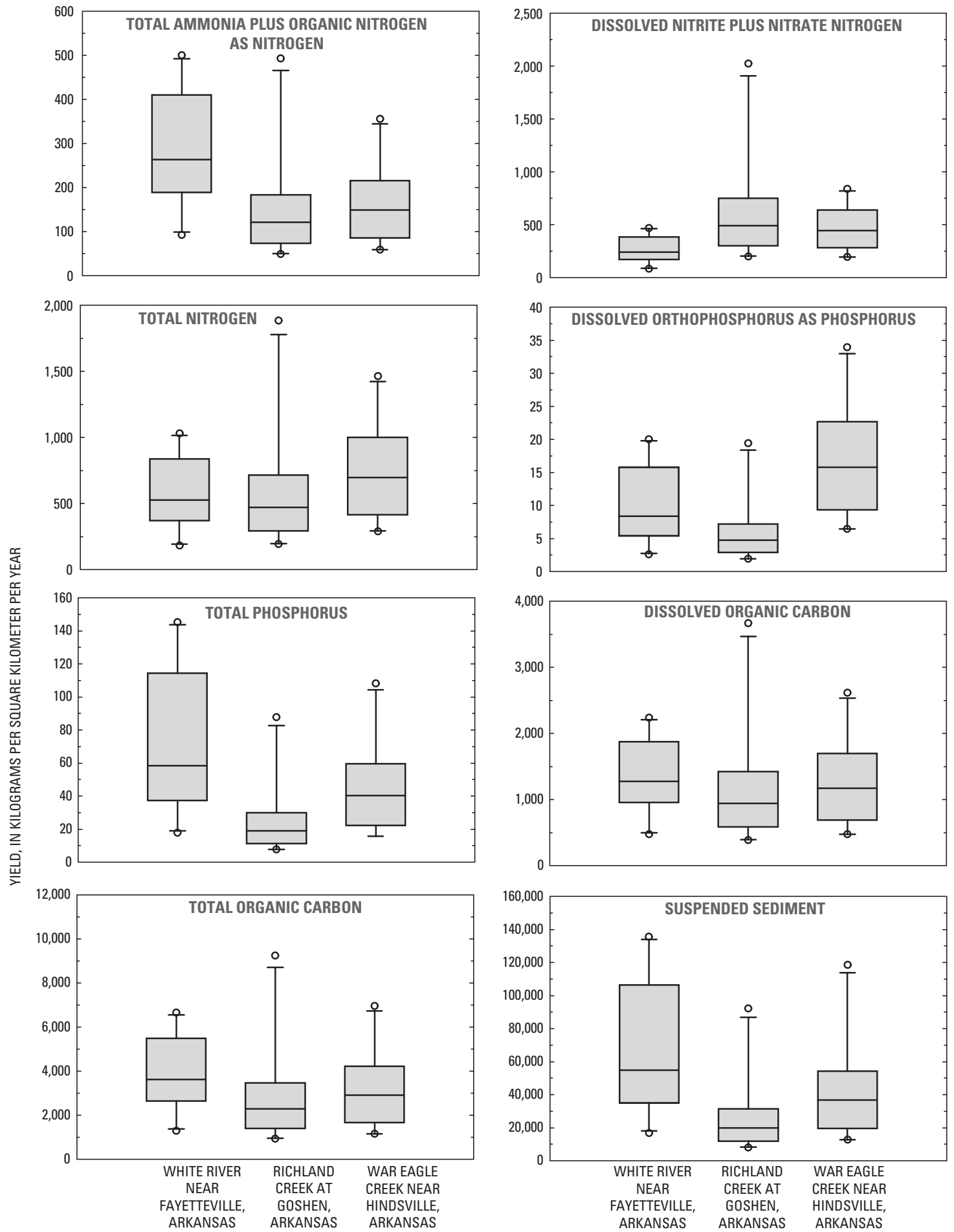

EXPLANATION

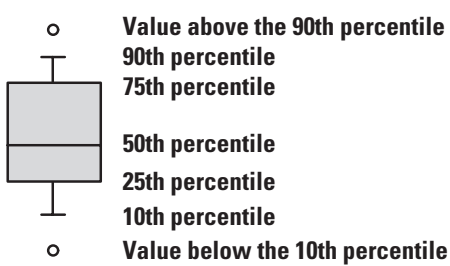

Figure 15. Distributions of annual nutrient, organic carbon, and sediment yields from water samples collected at White River near Fayetteville, Richland Creek at Goshen, and War Eagle Creek near Hindsville, Arkansas, water years 1999-2008. 


\section{Selected References}

Brenton, R.W., and Arnett, T.L., 1993, Methods of analysis by the U.S. Geological Survey National Water Quality Laboratory; determination of dissolved organic carbon by UV-promoted persulfate oxidation and infrared spectrometry: U.S. Geological Survey Open-File Report 92-480, 12 p.

Childress, C.J.O., Foreman, W.T., Connor, B.F., and Maloney, T.J., 1999, New reporting procedures based on longterm method detection levels and some considerations for interpretations of water-quality data provided by the U.S. Geological Survey National Water Quality Laboratory: U.S. Geological Survey Open-File Report 99-193, 19 p.

Cohn, T.A., 1988, Adjusted maximum likelihood estimation of the moments of lognormal populations from type 1 censored samples: U.S. Geological Survey Open-File Report 88-350, $34 \mathrm{p}$.

Cohn, T.A., DeLong, L.L., Gilroy, E.J., Hirsch, R.M., and Wells, D.K., 1989, Estimating constituent loads: Water Resources Research, v. 2, no. 5, p. 937-942.

Cohn, T.A., Gilroy, E.J., and Baier, W.G., 1992, Estimating fluvial transport of trace constituents using a regression model with data subject to censoring: Proceedings of the Joint Statistical Meeting, Boston, Mass., August 9-13, 1992, p. 142-151.

Crawford, C.G., 1991, Estimation of suspended-sediment rating curves and mean suspended-sediment loads: Journal of Hydrology, v. 129, p. 331-348.

Dempster, A.P., Laird, N.M., and Rubin, D.B., 1977, Maximum likelihood from incomplete data via the EM algorithm: Journal of the Royal Statistical Society, Series B, v. 39 , no. 1, p. 1-38.

Edwards, T.K., and Glysson, G.D., 1999, Field methods for measurement of fluvial sediment: U.S. Geological Survey Techniques of Water-Resources Investigations, book 3, chap. C2, 89 p.

Fishman, M.J., ed., 1993, Field methods of analysis by the U.S. Geological Survey National Water Quality Laboratory; determination of inorganic and organic constituents in water and fluvial sediments: U.S. Geological Survey Open-File Report 93-125, 217 p.

Funkhouser, J.E., and Eng, Ken, 2009, Floods of selected streams in Arkansas, spring 2008: U.S. Geological Survey Fact Sheet 2008-3103, 4 p.
Galloway, J.M., and Green, W.R., 2006a, Analysis of ambient conditions and simulation of hydrodynamics and water-quality characteristics in Beaver Lake, Arkansas, 2001 through 2003: U.S. Geological Survey Scientific Investiga $\neg$ tions Report 2006-5003, 55 p.

Galloway, J.M., Green, W.R., 2006b, Application of a twodimensional reservoir water-quality model of Beaver Lake, Arkansas, for the evaluation of simulated changes in input water quality, 2001-2003: U.S. Geological Survey Scientific Investigations Report 2006-5302, 39 p.

Gilroy, E.J., Hirsch, R.M., and Cohn, T.A., 1990, Mean square error of regression-based constituent transport estimates: Water Resources Research, v. 26, no. 9, p. 2,069-2,077.

Guy, H.P., 1969, Laboratory theory and methods for sediment analysis: U.S. Geological Survey Techniques of WaterResources Investigations, book 5, chap. $\mathrm{C} 1,58 \mathrm{p}$.

Haggard, B.E., and Green, W.R., 2002, Simulation of hydrodynamics, temperature, and dissolved oxygen in Beaver Lake, Arkansas, 1994-1995: U.S. Geological Survey WaterResources Investigations Report 02-4116, 21 p.

Helsel, D.R., and Hirsch, R. M., 2002, Statistical methods in water resources: U.S. Geological Survey Techniques of Water-Resources Investigations, book 4, chap. A3, 522 p.

Likes, Jiri, 1980, Variance of the MVUE for lognormal variance: Technometrics, v. 22, no. 2, p. 253-258.

Rantz, S.E., and others, 1982, Measurement and computation of streamflow - Volume 2. Computation of discharge: U.S. Geological Survey Water-Supply Paper 2175, v. 2, p. 285-631.

Runkel, R.L., Crawford, C.G., and Cohn, T.A., 2004, Load estimator (LOADEST) - A FORTRAN program for estimating constituent loads in streams and rivers: U.S. Geological Survey Techniques and Methods, book 4, chap. A5, accessed August 2009 at http://pubs.er.usgs.gov/usgspubs/tm/tm4A5

TIBCO Software Inc., 2008, TIBCO Spotfire S+ 8.1 for Windows.

Timme, P.J., 1995, National Water Quality Laboratory 1995 Services Catalog: U.S. Geological Survey Open-File Report 95-352, p. 92.

U.S. Army Corps of Engineers, 1997, Hydrologic engineering requirements for reservoirs: U.S. Army Corps of Engineers Engineering Manual 1110-2-1420, variously paginated. 
U.S. Census Bureau, 2009, 1999 and 2000 census of population and housing, population finder, summary tables, generated by Susan Bolyard using American FactFinder, http://factfinder.census.gov, accessed December 14, 2009.

U.S. Environmental Protection Agency, 1997, Guidelines establishing test procedures for the analysis of pollutants (App. B, Part 136, Definition and procedures for the determination of the method detection limit): U.S. Code of Federal Regulations, Title 40, revised July 1, 1997, p. 265-267.

U.S. Geological Survey, variously dated, National field manual for the collection of water-quality data: U.S. Geological Survey Techniques of Water-Resources Investigations, book 9, chaps. A1-A9, available online at http://pubs.water.usgs. gov/twri9A.

U.S. Geological Survey, 2009, National Water Information System, accessed August 10, 2009, at http://pubs.er.usgs. gov/usgspubs/tm/tm4A5.

Wershaw, R.L., Fishman, M.J., Grabbe, R.R., and Lowe, L.E., eds., 1987, Methods for the determination of organic substances in water and fluvial sediments: U.S. Geological Survey Techniques of Water-Resources Investigations, book 5, chap. A3, 80 p.

Wilde, F.D., and Radke, D.B., 1998, Field measurements: U.S. Geological Survey Techniques of Water-Resources Investigations, book 9 , chap. A6, variously paginated.

Wilde, F.D., Radke, D.B., Gibs, J., Iwatsubo, R.T., 1998, Cleaning of equipment for water sampling: U.S. Geological Survey Techniques of Water-Resources Investigations, book 9 , chap. A3, variously paginated.

Wolynetz, M.S., 1979, Algorithm 139 - Maximum likelihood estimation in a linear model with confined and censored data: Applied Statistics, v. 28, p. 195-206. 
Appendix 1. Water-quality data results modified from NWIS data for White River near Fayetteville (07048600), Richland Creek at Goshen (07048800), and War Eagle Creek near Hindsville (07049000).

[Units are in milligrams per liter unless otherwise noted; $\mathrm{m}^{3} / \mathrm{s}$, cubic meter per second; five-digit numbers in parentheses are STORET parameter codes used for computer storage of data; N, nitrogen; p, phosphorus; <, less than; --, missing data. When laboratory reporting limit (LRL) values were originally reported, less than values were modified by dividing the LRL by 2 to get the long-term method detection level (LT-MDL) and the resulting LT-MDL value is reported below]

\begin{tabular}{|c|c|c|c|c|c|c|c|c|c|c|}
\hline Date & Time & $\begin{array}{c}\text { Instan- } \\
\text { taneous } \\
\text { streamflow, } \\
\text { in } \mathrm{m}^{3} / \mathrm{s} \\
(30209)\end{array}$ & $\begin{array}{c}\text { Total } \\
\text { ammonia } \\
+ \text { organic, } \\
\text { as } N \\
(00625)\end{array}$ & $\begin{array}{c}\text { Dissolved } \\
\text { nitrite + } \\
\text { nitrate, } \\
\text { as } N \\
\text { (00631) }\end{array}$ & $\begin{array}{c}\text { Total } \\
\text { nitrogen } \\
(00600)\end{array}$ & $\begin{array}{c}\text { Dissolved } \\
\text { orthophos- } \\
\text { phorus, as P } \\
\text { (00671) }\end{array}$ & $\begin{array}{c}\text { Total } \\
\text { phosphorus } \\
\text { (00665) }\end{array}$ & $\begin{array}{c}\text { Dissolved } \\
\text { organic } \\
\text { carbon } \\
\text { (00681) }\end{array}$ & $\begin{array}{c}\text { Total } \\
\text { organic } \\
\text { carbon } \\
(00680)\end{array}$ & $\begin{array}{c}\text { Sus- } \\
\text { pended } \\
\text { sediment } \\
(80154)\end{array}$ \\
\hline $11 / 04 / 1999$ & 1200 & 0.311 & 0.31 & 0.36 & 0.67 & 0.010 & 0.030 & --- & --- & 39 \\
\hline $12 / 09 / 1999$ & 1330 & 5.32 & 0.33 & 0.86 & 1.2 & $<0.010$ & 0.050 & --- & --- & 36 \\
\hline $12 / 12 / 1999$ & 1715 & 180 & 0.64 & 1.2 & 1.8 & $<0.010$ & 0.130 & --- & --- & 167 \\
\hline $02 / 09 / 2000$ & 945 & 2.44 & $<0.10$ & 0.80 & --- & $<0.010$ & $<0.010$ & --- & --- & 32 \\
\hline $04 / 13 / 2000$ & 1200 & 17.6 & 0.38 & 0.46 & 0.84 & $<0.010$ & 0.030 & --- & --- & 43 \\
\hline $05 / 07 / 2000$ & 1700 & 28.9 & 0.42 & 0.29 & 0.71 & $<0.010$ & 0.050 & --- & --- & 56 \\
\hline $05 / 25 / 2000$ & 1010 & 9.77 & 0.33 & 0.21 & 0.54 & $<0.010$ & 0.060 & --- & -- & 63 \\
\hline $05 / 26 / 2000$ & 840 & 3.17 & 0.33 & 0.23 & 0.56 & $<0.010$ & 0.050 & --- & --- & 39 \\
\hline $05 / 27 / 2000$ & 1500 & 512 & 2.6 & 0.43 & 3.0 & 0.010 & 0.600 & --- & --- & 738 \\
\hline $06 / 14 / 2000$ & 1900 & 69.7 & 0.92 & 0.42 & 1.3 & 0.050 & 0.200 & --- & --- & 206 \\
\hline $06 / 14 / 2000$ & 2240 & 90.0 & 0.91 & 0.41 & 1.3 & 0.020 & 0.140 & --- & --- & 189 \\
\hline $06 / 17 / 2000$ & 1315 & 408 & 1.9 & 0.40 & 2.3 & 0.110 & 0.420 & -- & --- & 421 \\
\hline $06 / 17 / 2000$ & 1745 & 583 & 2.0 & 0.40 & 2.4 & 0.100 & 0.520 & --- & --- & 542 \\
\hline $06 / 18 / 2000$ & 1140 & 143 & 0.62 & 0.58 & 1.2 & 0.030 & 0.140 & --- & --- & 111 \\
\hline 08/08/2000 & 1030 & 0.538 & 0.36 & 0.16 & 0.52 & 0.010 & 0.030 & --- & --- & 36 \\
\hline $10 / 12 / 2000$ & 1330 & 0.963 & 0.32 & 0.26 & 0.58 & $<0.005$ & $<0.010$ & --- & --- & 57 \\
\hline $01 / 08 / 2001$ & 1100 & 14.2 & $<0.10$ & 1.4 & --- & $<0.005$ & 0.030 & --- & --- & 28 \\
\hline $02 / 14 / 2001$ & 1930 & 100 & 1.8 & 0.88 & 2.7 & 0.020 & 0.390 & --- & --- & 712 \\
\hline $02 / 15 / 2001$ & 1315 & 317 & 1.1 & 1.0 & 2.1 & $<0.005$ & 0.220 & --- & --- & 280 \\
\hline $02 / 17 / 2001$ & 715 & 119 & 0.38 & 1.3 & 1.7 & 0.010 & 0.030 & --- & --- & 50 \\
\hline $03 / 13 / 2001$ & 930 & 9.06 & 0.28 & 1.3 & 1.6 & $<0.005$ & $<0.010$ & --- & --- & 29 \\
\hline $04 / 04 / 2001$ & 1115 & 4.33 & $<0.10$ & 0.73 & --- & $<0.005$ & $<0.010$ & 1.6 & 2.1 & 28 \\
\hline $04 / 17 / 2001$ & 845 & 10.3 & 0.27 & 0.45 & 0.72 & $<0.005$ & 0.020 & 1.6 & 1.8 & 24 \\
\hline 05/01/2001 & 1130 & 3.17 & 0.29 & 0.23 & 0.52 & $<0.005$ & $<0.010$ & 0.8 & 1.1 & 25 \\
\hline $05 / 15 / 2001$ & 1330 & 3.74 & 0.47 & 0.24 & 0.71 & $<0.005$ & 0.020 & 1.9 & 1.5 & 24 \\
\hline $05 / 16 / 2001$ & 1400 & 3.00 & 0.30 & 0.21 & 0.51 & $<0.005$ & $<0.010$ & --- & --- & 38 \\
\hline $05 / 30 / 2001$ & 1400 & 16.2 & 0.55 & 0.32 & 0.87 & $<0.005$ & 0.050 & 2.9 & 2.6 & 72 \\
\hline $05 / 30 / 2001$ & 1430 & 16.7 & 0.59 & 0.32 & 0.91 & $<0.005$ & $<0.010$ & --- & --- & 72 \\
\hline $06 / 12 / 2001$ & 1315 & 1.61 & 0.29 & 0.12 & 0.41 & 0.020 & 0.020 & 2.6 & 2.7 & 20 \\
\hline $06 / 15 / 2001$ & 1015 & 31.7 & 0.69 & 0.18 & 0.87 & 0.010 & 0.090 & --- & --- & 70 \\
\hline $06 / 26 / 2001$ & 815 & 0.934 & 0.42 & 0.20 & 0.62 & $<0.005$ & 0.030 & 3.3 & 2.4 & 32 \\
\hline $07 / 09 / 2001$ & 1345 & 0.736 & 0.50 & 0.18 & 0.68 & $<0.005$ & $<0.010$ & 4.3 & 3.1 & 31 \\
\hline 07/13/2001 & 1400 & 24.5 & 0.70 & 0.09 & 0.79 & $<0.005$ & 0.060 & --- & --- & 64 \\
\hline $07 / 18 / 2001$ & 900 & 6.00 & 0.83 & 0.43 & 1.3 & 0.010 & 0.130 & --- & --- & 127 \\
\hline $07 / 23 / 2001$ & 1100 & 1.08 & 0.49 & 0.24 & 0.73 & $<0.005$ & 0.030 & 2.9 & 2.4 & 33 \\
\hline 08/06/2001 & 1415 & 0.340 & 0.30 & 0.15 & 0.45 & $<0.005$ & $<0.010$ & 3.2 & 2.4 & 33 \\
\hline
\end{tabular}


Appendix 1. Water-quality data results modified from NWIS data for White River near Fayetteville (07048600), Richland Creek at Goshen (07048800), and War Eagle Creek near Hindsville (07049000).—Continued

[Units are in milligrams per liter unless otherwise noted; $\mathrm{m}^{3} / \mathrm{s}$, cubic meter per second; five-digit numbers in parentheses are STORET parameter codes used for computer storage of data; N, nitrogen; p, phosphorus; <, less than; --, missing data. When laboratory reporting limit (LRL) values were originally reported, less than values were modified by dividing the LRL by 2 to get the long-term method detection level (LT-MDL) and the resulting LT-MDL value is reported below]

\begin{tabular}{|c|c|c|c|c|c|c|c|c|c|c|}
\hline Date & Time & $\begin{array}{c}\text { Instan- } \\
\text { taneous } \\
\text { streamflow, } \\
\text { in } \mathrm{m}^{3} / \mathrm{s} \\
(30209)\end{array}$ & $\begin{array}{c}\text { Total } \\
\text { ammonia } \\
+ \text { organic, } \\
\text { as } N \\
(00625)\end{array}$ & $\begin{array}{c}\text { Dissolved } \\
\text { nitrite + } \\
\text { nitrate, } \\
\text { as N } \\
\text { (00631) }\end{array}$ & $\begin{array}{c}\text { Total } \\
\text { nitrogen } \\
(00600)\end{array}$ & $\begin{array}{c}\text { Dissolved } \\
\text { orthophos- } \\
\text { phorus, as P } \\
\text { (00671) }\end{array}$ & $\begin{array}{c}\text { Total } \\
\text { phosphorus } \\
(00665)\end{array}$ & $\begin{array}{l}\text { Dissolved } \\
\text { organic } \\
\text { carbon } \\
\text { (00681) }\end{array}$ & $\begin{array}{c}\text { Total } \\
\text { organic } \\
\text { carbon } \\
(00680)\end{array}$ & $\begin{array}{c}\text { Sus- } \\
\text { pended } \\
\text { sediment } \\
(80154)\end{array}$ \\
\hline $08 / 21 / 2001$ & 1330 & 0.425 & 0.50 & 0.40 & 0.90 & $<0.005$ & 0.030 & 3.8 & 3.9 & 33 \\
\hline 09/04/2001 & 1100 & 0.453 & 0.60 & 0.31 & 0.91 & $<0.005$ & $<0.010$ & --- & --- & 28 \\
\hline 09/05/2001 & 1215 & 0.368 & 0.50 & 0.28 & 0.78 & $<0.005$ & $<0.010$ & 4.3 & 3.8 & 22 \\
\hline 09/17/2001 & 1230 & 9.26 & 1.1 & 0.41 & 1.5 & 0.050 & 0.220 & 4.6 & 3.9 & 148 \\
\hline $10 / 01 / 2001$ & 1250 & 0.765 & 0.30 & 0.44 & 0.74 & $<0.005$ & $<0.010$ & 3.6 & 3.6 & 32 \\
\hline $10 / 10 / 2001$ & 2320 & 151 & $<0.10$ & 0.33 & --- & 0.020 & 0.580 & --- & --- & 950 \\
\hline $10 / 11 / 2001$ & 355 & 120 & $<0.10$ & 0.50 & --- & 0.080 & 0.180 & --- & --- & 276 \\
\hline $10 / 11 / 2001$ & 1530 & 67.7 & $<0.10$ & 0.29 & --- & 0.040 & 0.230 & --- & --- & 99 \\
\hline $10 / 15 / 2001$ & 1400 & 17.8 & $<0.10$ & 0.96 & --- & 0.040 & 0.070 & 4.3 & 4.9 & 37 \\
\hline $10 / 24 / 2001$ & 1100 & 2.75 & 0.20 & 0.97 & 1.2 & $<0.005$ & 0.020 & --- & --- & 37 \\
\hline $10 / 29 / 2001$ & 1315 & 1.44 & 0.30 & 0.78 & 1.1 & $<0.005$ & $<0.010$ & 2.5 & 2.7 & 23 \\
\hline $11 / 07 / 2001$ & 1530 & 4.98 & 0.40 & 1.0 & 1.4 & 0.010 & $<0.010$ & 4.2 & 5.6 & 55 \\
\hline $11 / 26 / 2001$ & 1345 & 6.43 & $<0.10$ & 0.32 & --- & $<0.005$ & $<0.010$ & 2.9 & 4.3 & 26 \\
\hline $12 / 04 / 2001$ & 1030 & 13.7 & $<0.10$ & 0.57 & --- & $<0.005$ & 0.030 & --- & --- & 38 \\
\hline $12 / 10 / 2001$ & 1400 & 7.99 & $<0.10$ & 0.59 & --- & 0.010 & 0.030 & 1.3 & 1.4 & 24 \\
\hline $12 / 17 / 2001$ & 415 & 816 & 1.6 & 0.57 & 2.2 & $<0.005$ & 0.420 & 6.8 & 7.0 & 462 \\
\hline $12 / 17 / 2001$ & 745 & 699 & 1.3 & 0.58 & 1.9 & 0.030 & 0.310 & --- & --- & 349 \\
\hline $12 / 17 / 2001$ & 1745 & 239 & 0.60 & 0.78 & 1.4 & 0.020 & 0.140 & --- & --- & 130 \\
\hline $01 / 03 / 2002$ & 915 & 6.00 & $<0.10$ & 1.2 & --- & $<0.005$ & $<0.010$ & 3.8 & 4.0 & 25 \\
\hline $01 / 14 / 2002$ & 1230 & 3.11 & $<0.10$ & 1.0 & --- & $<0.005$ & $<0.010$ & 1.5 & 1.8 & 16 \\
\hline $01 / 31 / 2002$ & 1245 & 266 & 1.3 & 0.62 & 1.9 & 0.050 & 0.240 & --- & --- & 306 \\
\hline $02 / 06 / 2002$ & 1215 & 22.0 & $<0.10$ & 0.93 & --- & $<0.005$ & $<0.010$ & 1.7 & 1.9 & 19 \\
\hline $02 / 20 / 2002$ & 1145 & 40.5 & 0.70 & 0.64 & 1.3 & 0.020 & 0.070 & 3.6 & 4.1 & 63 \\
\hline $03 / 05 / 2002$ & 1400 & 16.2 & $<0.10$ & 0.57 & --- & 0.030 & $<0.010$ & 1.8 & 2.2 & 21 \\
\hline 03/07/2002 & 1000 & 16.5 & $<0.10$ & 0.51 & --- & $<0.005$ & $<0.010$ & --- & --- & 23 \\
\hline 03/19/2002 & 745 & 221 & 0.80 & 0.45 & 1.2 & 0.050 & 0.180 & 5.2 & 5.1 & 179 \\
\hline $04 / 02 / 2002$ & 1630 & 17.9 & $<0.10$ & 0.58 & --- & $<0.005$ & $<0.010$ & 0.8 & --- & 23 \\
\hline $04 / 07 / 2002$ & 2030 & 209 & 1.0 & 0.48 & 1.5 & 0.020 & 0.200 & --- & --- & 373 \\
\hline $04 / 16 / 2002$ & 1315 & 16.9 & $<0.10$ & 0.58 & --- & $<0.005$ & $<0.010$ & 1.0 & 1.0 & 29 \\
\hline $04 / 30 / 2002$ & 1400 & 14.8 & $<0.10$ & 0.30 & --- & $<0.005$ & 0.020 & 1.0 & 1.5 & 30 \\
\hline $05 / 13 / 2002$ & 1745 & 13.8 & 0.60 & 0.27 & 0.87 & $<0.005$ & 0.040 & 2.6 & 2.8 & 40 \\
\hline $05 / 15 / 2002$ & 1430 & 6.82 & 0.50 & 0.03 & 0.80 & $<0.005$ & 0.050 & --- & --- & 29 \\
\hline $05 / 17 / 2002$ & 1300 & 76.2 & 1.3 & 0.25 & 1.6 & 0.030 & 0.120 & --- & --- & 206 \\
\hline $05 / 29 / 2002$ & 915 & 7.48 & 0.20 & 0.22 & 0.42 & 0.010 & $<0.010$ & 1.9 & 1.6 & 26 \\
\hline $06 / 17 / 2002$ & 1815 & 8.78 & 0.40 & 0.17 & 0.57 & 0.020 & 0.040 & 2.6 & 2.3 & 14 \\
\hline $07 / 08 / 2002$ & 1115 & 0.991 & 0.30 & 0.15 & 0.45 & 0.020 & 0.040 & 2.2 & 2.1 & 11 \\
\hline
\end{tabular}


Appendix 1. Water-quality data results modified from NWIS data for White River near Fayetteville (07048600), Richland Creek at Goshen (07048800), and War Eagle Creek near Hindsville (07049000).-Continued

[Units are in milligrams per liter unless otherwise noted; $\mathrm{m}^{3} / \mathrm{s}$, cubic meter per second; five-digit numbers in parentheses are STORET parameter codes used for computer storage of data; N, nitrogen; , phosphorus; <, less than; --, missing data. When laboratory reporting limit (LRL) values were originally reported, less than values were modified by dividing the LRL by 2 to get the long-term method detection level (LT-MDL) and the resulting LT-MDL value is reported below]

\begin{tabular}{|c|c|c|c|c|c|c|c|c|c|c|}
\hline Date & Time & $\begin{array}{c}\text { Instan- } \\
\text { taneous } \\
\text { streamflow, } \\
\text { in } \mathrm{m}^{3} / \mathrm{s} \\
(30209)\end{array}$ & $\begin{array}{c}\text { Total } \\
\text { ammonia } \\
+ \text { organic, } \\
\text { as N } \\
\text { (00625) }\end{array}$ & $\begin{array}{c}\text { Dissolved } \\
\text { nitrite + } \\
\text { nitrate, } \\
\text { as N } \\
\text { (00631) }\end{array}$ & $\begin{array}{c}\text { Total } \\
\text { nitrogen } \\
(00600)\end{array}$ & $\begin{array}{c}\text { Dissolved } \\
\text { orthophos- } \\
\text { phorus, as P } \\
\text { (00671) }\end{array}$ & $\begin{array}{c}\text { Total } \\
\text { phosphorus } \\
\text { (00665) }\end{array}$ & $\begin{array}{l}\text { Dissolved } \\
\text { organic } \\
\text { carbon } \\
\text { (00681) }\end{array}$ & $\begin{array}{c}\text { Total } \\
\text { organic } \\
\text { carbon } \\
(00680)\end{array}$ & $\begin{array}{l}\text { Sus- } \\
\text { pended } \\
\text { sediment } \\
\text { (80154) }\end{array}$ \\
\hline $07 / 22 / 2002$ & 1600 & 3.88 & 0.40 & 0.14 & 0.54 & $<0.005$ & 0.040 & 2.8 & 2.8 & 22 \\
\hline $07 / 25 / 2002$ & 800 & 6.82 & $<0.10$ & 0.05 & --- & $<0.005$ & 0.030 & --- & --- & 15 \\
\hline $08 / 21 / 2002$ & 1450 & 3.00 & 0.20 & 0.35 & 0.55 & $<0.005$ & 0.040 & 2.4 & 2.1 & 23 \\
\hline $08 / 28 / 2002$ & 1300 & 0.934 & 0.40 & 0.17 & 0.57 & $<0.005$ & 0.020 & --- & --- & 8 \\
\hline 09/03/2002 & 1430 & 0.481 & 0.40 & 0.11 & 0.51 & $<0.005$ & $<0.010$ & 2.2 & 1.9 & 9 \\
\hline $10 / 08 / 2002$ & 1130 & 0.119 & 0.40 & 0.10 & 0.50 & $<0.005$ & $<0.010$ & 3.2 & 2.9 & 2 \\
\hline $10 / 29 / 2002$ & 1545 & 0.680 & 0.40 & 0.28 & 0.68 & 0.020 & 0.060 & 4.0 & 3.3 & 52 \\
\hline $11 / 13 / 2002$ & 1010 & 0.139 & 0.60 & 0.11 & 0.71 & $<0.005$ & $<0.010$ & 3.2 & 2.9 & 3 \\
\hline $12 / 11 / 2002$ & 1445 & 0.453 & 0.40 & 0.10 & 0.50 & $<0.005$ & $<0.010$ & 2.4 & 2.4 & 4 \\
\hline $12 / 18 / 2002$ & 1230 & 2.69 & 0.50 & 0.16 & 0.66 & 0.030 & 0.030 & 2.5 & 2.9 & 12 \\
\hline 01/07/2003 & 1330 & 1.13 & $<0.10$ & 0.99 & --- & $<0.005$ & 0.030 & 1.5 & 1.7 & 10 \\
\hline $01 / 22 / 2003$ & 1000 & 2.21 & 0.20 & 0.83 & 1.0 & $<0.005$ & 0.020 & 1.1 & 1.2 & 6 \\
\hline $02 / 12 / 2003$ & 1130 & 1.27 & 0.30 & 0.58 & 0.88 & $<0.005$ & $<0.010$ & 2.3 & 2.6 & 19 \\
\hline $03 / 11 / 2003$ & 1345 & 6.63 & $<0.10$ & 0.67 & --- & $<0.005$ & 0.010 & 1.0 & 1.0 & 11 \\
\hline $03 / 25 / 2003$ & 1515 & 17.6 & $<0.10$ & 0.50 & --- & $<0.005$ & 0.020 & 1.2 & 1.1 & 14 \\
\hline $04 / 08 / 2003$ & 1450 & 5.15 & $<0.10$ & 0.30 & --- & $<0.005$ & 0.030 & 1.2 & 1.1 & 23 \\
\hline $05 / 05 / 2003$ & 1530 & 6.48 & $<0.10$ & 0.20 & --- & $<0.005$ & 0.020 & 1.0 & 0.9 & 29 \\
\hline 06/03/2003 & 30 & 48.1 & 0.70 & 0.37 & 1.1 & 0.040 & 0.150 & 4.8 & 4.3 & 84 \\
\hline $06 / 05 / 2003$ & 1445 & 13.3 & 0.30 & 0.33 & 0.63 & 0.010 & 0.060 & 2.6 & 2.6 & 35 \\
\hline 07/29/2003 & 1615 & 1.33 & 0.30 & 0.03 & 0.33 & $<0.005$ & $<0.010$ & 1.7 & 1.5 & 27 \\
\hline $08 / 20 / 2003$ & 1300 & 0.278 & 0.30 & 0.17 & 0.47 & $<0.005$ & $<0.010$ & 2.8 & 2.7 & 24 \\
\hline 09/09/2003 & 1330 & 0.425 & 0.30 & 0.41 & 0.71 & $<0.005$ & 0.020 & 2.8 & 2.9 & 28 \\
\hline $10 / 28 / 2003$ & 1340 & 0.906 & 0.40 & 0.19 & 0.59 & 0.010 & $<0.010$ & 2.1 & 2.0 & 20 \\
\hline $11 / 18 / 2003$ & 1115 & 53.0 & 0.40 & 0.34 & 0.74 & 0.010 & 0.040 & 1.7 & 1.8 & 37 \\
\hline $11 / 19 / 2003$ & 730 & 33.4 & 0.50 & 0.41 & 0.91 & $<0.005$ & 0.050 & 3.1 & 3.4 & 42 \\
\hline $12 / 09 / 2003$ & 1345 & 6.40 & 0.20 & 0.68 & 0.88 & $<0.005$ & 0.040 & 1.5 & 1.5 & 41 \\
\hline $01 / 21 / 2004$ & 1415 & 21.4 & $<0.10$ & 0.66 & --- & $<0.005$ & $<0.010$ & 1.3 & 1.4 & 23 \\
\hline $02 / 18 / 2004$ & 1345 & 10.4 & $<0.10$ & 0.55 & --- & $<0.005$ & $<0.010$ & 1.0 & 1.4 & 46 \\
\hline 03/05/2004 & 1100 & 81.8 & 1.3 & 0.53 & 1.8 & 0.040 & 0.230 & --- & --- & 205 \\
\hline 03/17/2004 & 1230 & 9.09 & $<0.10$ & 0.51 & --- & $<0.005$ & 0.030 & 1.1 & 0.7 & 29 \\
\hline $04 / 13 / 2004$ & 1315 & 14.7 & $<0.10$ & 0.26 & --- & $<0.005$ & $<0.010$ & 1.4 & 1.3 & 26 \\
\hline $04 / 22 / 2004$ & 1415 & 178 & 1.0 & 0.33 & 1.3 & 0.040 & 0.190 & 7.5 & 6.8 & 134 \\
\hline 05/19/2004 & 1245 & 9.29 & 0.20 & 0.26 & 0.46 & $<0.005$ & $<0.010$ & 1.8 & 1.6 & 26 \\
\hline $06 / 22 / 2004$ & 1420 & 82.1 & 0.70 & 0.37 & 1.1 & 0.020 & 0.150 & 5.1 & 5.2 & 120 \\
\hline $06 / 23 / 2004$ & 1015 & 51.8 & 0.40 & 1.3 & 1.7 & 0.020 & 0.090 & 4.5 & 4.6 & 62 \\
\hline $07 / 21 / 2004$ & 1130 & 5.10 & 0.29 & 0.11 & 0.40 & $<0.010$ & 0.020 & 2.0 & 4.3 & 22 \\
\hline
\end{tabular}


Appendix 1. Water-quality data results modified from NWIS data for White River near Fayetteville (07048600), Richland Creek at Goshen (07048800), and War Eagle Creek near Hindsville (07049000).-Continued

[Units are in milligrams per liter unless otherwise noted; $\mathrm{m}^{3} / \mathrm{s}$, cubic meter per second; five-digit numbers in parentheses are STORET parameter codes used for computer storage of data; $\mathrm{N}$, nitrogen; $\mathrm{p}$, phosphorus; $<$, less than; --, missing data. When laboratory reporting limit (LRL) values were originally reported, less than values were modified by dividing the LRL by 2 to get the long-term method detection level (LT-MDL) and the resulting LT-MDL value is reported below]

\begin{tabular}{|c|c|c|c|c|c|c|c|c|c|c|}
\hline Date & Time & $\begin{array}{c}\text { Instan- } \\
\text { taneous } \\
\text { streamflow, } \\
\text { in } \mathrm{m}^{3} / \mathrm{s} \\
(30209)\end{array}$ & $\begin{array}{c}\text { Total } \\
\text { ammonia } \\
+ \text { organic, } \\
\text { as } N \\
\text { (00625) }\end{array}$ & $\begin{array}{c}\text { Dissolved } \\
\text { nitrite + } \\
\text { nitrate, } \\
\text { as N } \\
\text { (00631) }\end{array}$ & $\begin{array}{c}\text { Total } \\
\text { nitrogen } \\
(00600)\end{array}$ & $\begin{array}{c}\text { Dissolved } \\
\text { orthophos- } \\
\text { phorus, as P } \\
\text { (00671) }\end{array}$ & $\begin{array}{c}\text { Total } \\
\text { phosphorus } \\
(00665)\end{array}$ & $\begin{array}{l}\text { Dissolved } \\
\text { organic } \\
\text { carbon } \\
\text { (00681) }\end{array}$ & $\begin{array}{c}\text { Total } \\
\text { organic } \\
\text { carbon } \\
(00680)\end{array}$ & $\begin{array}{c}\text { Sus- } \\
\text { pended } \\
\text { sediment } \\
\text { (80154) }\end{array}$ \\
\hline 08/11/2004 & 1200 & 3.20 & 0.31 & 0.07 & 0.38 & $<0.010$ & 0.040 & 1.8 & 3.3 & 32 \\
\hline 09/09/2004 & 1400 & 0.396 & 0.24 & 0.10 & 0.35 & $<0.010$ & $<0.020$ & 2.0 & 3.2 & 22 \\
\hline $10 / 05 / 2004$ & 1215 & 0.283 & 0.26 & 0.12 & 0.38 & $<0.003$ & 0.027 & 2.3 & 5.1 & 31 \\
\hline $11 / 01 / 2004$ & 1515 & 320 & 1.2 & 0.464 & 1.6 & 0.036 & 0.230 & 5.0 & 12.6 & 347 \\
\hline $11 / 03 / 2004$ & 1440 & 37.9 & 0.28 & 0.728 & 1.0 & 0.007 & 0.071 & 1.9 & 3.6 & 49 \\
\hline $01 / 03 / 2005$ & 1945 & 147 & 0.79 & 0.539 & 1.3 & 0.042 & 0.190 & 5.4 & 9.4 & 142 \\
\hline 01/11/2005 & 1600 & 24.5 & 0.14 & 0.812 & 0.95 & $<0.003$ & 0.024 & 1.7 & 1.9 & 36 \\
\hline 03/08/2005 & 1500 & 9.80 & 0.16 & 0.275 & 0.44 & $<0.003$ & 0.020 & 0.9 & 1.6 & 14 \\
\hline $04 / 18 / 2005$ & 1340 & 15.0 & 0.15 & 0.306 & 0.45 & $<0.003$ & 0.021 & 1.1 & 1.3 & 12 \\
\hline 06/29/2005 & 1515 & 0.266 & 0.35 & 0.093 & 0.44 & $<0.003$ & 0.040 & 3.0 & 4.3 & 15 \\
\hline 08/17/2005 & 1500 & 0.0934 & 0.39 & 0.187 & 0.58 & $<0.020$ & 0.019 & 3.2 & 3.7 & 21 \\
\hline $10 / 19 / 2005$ & 1400 & 0.0651 & 0.30 & 0.288 & 0.58 & $<0.015$ & 0.023 & 3.9 & 3.0 & 32 \\
\hline $12 / 19 / 2005$ & 1430 & 0.119 & 0.45 & 0.111 & 0.56 & $<0.015$ & 0.091 & 2.7 & 5.1 & 42 \\
\hline $02 / 23 / 2006$ & 1540 & 1.02 & 0.26 & 0.220 & 0.48 & $<0.015$ & 0.025 & 2.1 & 3.6 & 8 \\
\hline $05 / 02 / 2006$ & 1200 & 26.6 & 0.27 & 0.390 & 0.66 & $<0.090$ & 0.043 & 1.8 & 4.1 & 32 \\
\hline 05/04/2006 & 1415 & 276 & 1.8 & 0.369 & 2.2 & 0.003 & 0.330 & 3.4 & 19.5 & 695 \\
\hline 05/23/2006 & 830 & 6.57 & 0.19 & 0.124 & 0.31 & $<0.003$ & 0.013 & 1.3 & 1.7 & 9 \\
\hline 07/19/2006 & 900 & 0.0850 & 0.34 & 0.172 & 0.52 & 0.004 & 0.030 & 2.4 & 3.4 & 5 \\
\hline 08/23/2006 & 1330 & 42.2 & 2.0 & 1.08 & 3.0 & 0.044 & 0.390 & 4.9 & 17.5 & 533 \\
\hline 08/29/2006 & 1600 & 2.55 & 0.61 & 0.572 & 1.2 & 0.012 & 0.086 & 3.9 & 6.1 & 40 \\
\hline $11 / 01 / 2006$ & 1215 & 1.73 & 0.22 & 0.489 & 0.71 & 0.003 & 0.026 & 10.9 & 2.1 & 8 \\
\hline $12 / 13 / 2006$ & 1230 & 8.92 & 0.16 & 0.974 & 1.1 & $<0.003$ & 0.019 & 7.2 & 1.2 & 7 \\
\hline $01 / 13 / 2007$ & 1615 & 323 & 0.76 & 0.429 & 1.2 & 0.040 & 0.199 & 4.3 & 9.3 & 151 \\
\hline $02 / 13 / 2007$ & 1430 & 123 & 0.61 & 0.468 & 1.1 & 0.024 & 0.141 & 4.1 & 6.4 & 84 \\
\hline 02/20/2007 & 1430 & 16.1 & 0.06 & 0.590 & 0.65 & 0.003 & 0.017 & 0.8 & 0.8 & 11 \\
\hline 05/29/2007 & 1245 & 7.53 & 0.19 & 0.157 & 0.34 & 0.004 & 0.024 & 1.3 & 2.1 & 12 \\
\hline 07/09/2007 & 1330 & 4.47 & 0.29 & 0.207 & 0.49 & 0.005 & 0.068 & 2.2 & 3.4 & 21 \\
\hline 09/04/2007 & 1640 & 0.0340 & 0.27 & 0.136 & 0.40 & 0.004 & 0.024 & 2.4 & 4.0 & 8 \\
\hline $10 / 22 / 2007$ & 1023 & 1.56 & 0.29 & 0.188 & 0.48 & 0.005 & 0.029 & 2.3 & 2.5 & 8 \\
\hline $01 / 14 / 2008$ & 945 & 5.44 & 0.22 & 0.508 & 0.72 & 0.004 & 0.028 & 1.2 & 2.0 & 12 \\
\hline $02 / 16 / 2008$ & 2333 & 129 & 1.6 & 0.537 & 2.2 & 0.029 & 0.360 & 3.9 & 12 & 563 \\
\hline $02 / 25 / 2008$ & 1513 & 21.2 & 0.18 & 1.05 & 1.2 & 0.004 & 0.027 & 1.0 & 1.4 & 14 \\
\hline 03/19/2008 & 1525 & 144 & 0.85 & 0.395 & 1.2 & 0.025 & 0.333 & 3.1 & 9.1 & 294 \\
\hline $04 / 10 / 2008$ & 1915 & 351 & 1.4 & 0.273 & 1.6 & 0.012 & 0.300 & 7.1 & 13.6 & 512 \\
\hline 05/06/2008 & 940 & 23.8 & 0.18 & 0.252 & 0.43 & 0.004 & 0.028 & 1.2 & 1.6 & 23 \\
\hline 06/13/2008 & 915 & 18.7 & 0.25 & 0.289 & 0.54 & 0.004 & 0.047 & 1.9 & 2.0 & 26 \\
\hline
\end{tabular}


Appendix 1. Water-quality data results modified from NWIS data for White River near Fayetteville (07048600), Richland Creek at Goshen (07048800), and War Eagle Creek near Hindsville (07049000).-Continued

[Units are in milligrams per liter unless otherwise noted; $\mathrm{m}^{3} / \mathrm{s}$, cubic meter per second; five-digit numbers in parentheses are STORET parameter codes used for computer storage of data; N, nitrogen; p, phosphorus; <, less than; --, missing data. When laboratory reporting limit (LRL) values were originally reported, less than values were modified by dividing the LRL by 2 to get the long-term method detection level (LT-MDL) and the resulting LT-MDL value is reported below]

\begin{tabular}{|c|c|c|c|c|c|c|c|c|c|c|}
\hline Date & Time & $\begin{array}{c}\begin{array}{c}\text { Instan- } \\
\text { taneous }\end{array} \\
\text { streamflow, } \\
\text { in } \mathrm{m}^{3} / \mathrm{s} \\
(30209)\end{array}$ & $\begin{array}{c}\text { Total } \\
\text { ammonia } \\
+ \text { organic, } \\
\text { as } \mathrm{N} \\
\text { (00625) }\end{array}$ & $\begin{array}{c}\text { Dissolved } \\
\text { nitrite + } \\
\text { nitrate, } \\
\text { as N } \\
\text { (00631) }\end{array}$ & $\begin{array}{c}\text { Total } \\
\text { nitrogen } \\
(00600)\end{array}$ & $\begin{array}{c}\text { Dissolved } \\
\text { orthophos- } \\
\text { phorus, as P } \\
\text { (00671) }\end{array}$ & $\begin{array}{c}\text { Total } \\
\text { phosphorus } \\
\text { (00665) }\end{array}$ & $\begin{array}{l}\text { Dissolved } \\
\text { organic } \\
\text { carbon } \\
\text { (00681) }\end{array}$ & $\begin{array}{c}\text { Total } \\
\text { organic } \\
\text { carbon } \\
(00680)\end{array}$ & $\begin{array}{c}\text { Sus- } \\
\text { pended } \\
\text { sediment } \\
\text { (80154) }\end{array}$ \\
\hline 07/09/2008 & 1450 & 45.3 & 0.79 & 0.290 & 1.1 & 0.019 & 0.143 & 3.7 & 7.3 & 142 \\
\hline $08 / 26 / 2008$ & 1120 & 1.02 & 0.45 & 0.448 & 0.90 & 0.008 & 0.084 & 3.4 & 4.5 & 33 \\
\hline \multicolumn{11}{|c|}{ Richland Creek at Goshen (07048800) } \\
\hline 04/04/2001 & 1415 & 0.340 & $<0.10$ & 1.5 & --- & $<0.005$ & $<0.010$ & 2.2 & 2.5 & 17 \\
\hline $04 / 17 / 2001$ & 800 & 0.906 & $<0.10$ & 1.2 & --- & $<0.005$ & $<0.010$ & 1.1 & 1.4 & 17 \\
\hline 05/01/2001 & 1000 & 0.538 & 0.21 & 0.65 & 0.86 & $<0.005$ & $<0.010$ & 0.6 & 0.9 & 19 \\
\hline 05/15/2001 & 1210 & 0.680 & 0.40 & 0.74 & 1.1 & $<0.005$ & $<0.010$ & 2.3 & 1.1 & 23 \\
\hline 05/30/2001 & 1130 & 0.906 & 0.32 & 0.63 & 0.95 & $<0.005$ & $<0.010$ & 1.4 & 1.5 & 27 \\
\hline $06 / 12 / 2001$ & 945 & 0.453 & 0.28 & 0.45 & 0.73 & 0.020 & $<0.010$ & 2.3 & 1.6 & 24 \\
\hline $06 / 26 / 2001$ & 715 & 0.110 & 0.22 & 0.60 & 0.82 & $<0.005$ & $<0.010$ & 1.5 & 0.8 & 24 \\
\hline 07/10/2001 & 1530 & 0.232 & 0.30 & 0.29 & 0.59 & $<0.005$ & $<0.010$ & 2.1 & 1.5 & 31 \\
\hline $07 / 23 / 2001$ & 1215 & 0.232 & 0.36 & 0.40 & 0.76 & $<0.005$ & 0.020 & 1.3 & 0.8 & 32 \\
\hline 08/07/2001 & 1125 & 0.0765 & 0.30 & 0.08 & 0.38 & $<0.005$ & $<0.010$ & 1.6 & 2.2 & 28 \\
\hline 08/23/2001 & 1445 & 0.0481 & 0.40 & 0.05 & 0.45 & $<0.005$ & $<0.010$ & 1.2 & 1.8 & 37 \\
\hline $09 / 05 / 2001$ & 915 & 0.0396 & $<0.10$ & 0.06 & --- & $<0.005$ & $<0.010$ & 2.4 & 1.9 & 33 \\
\hline 09/17/2001 & 1400 & 0.623 & $<0.10$ & 1.2 & --- & 0.010 & $<0.010$ & 1.7 & 1.7 & 27 \\
\hline $10 / 01 / 2001$ & 1400 & 0.368 & $<0.10$ & 1.2 & --- & $<0.005$ & $<0.010$ & 1.6 & 1.7 & 31 \\
\hline $10 / 15 / 2001$ & 1500 & 2.66 & $<0.10$ & 2.0 & --- & 0.020 & $<0.010$ & 2.8 & 2.8 & 29 \\
\hline $10 / 29 / 2001$ & 1430 & 0.453 & $<0.10$ & 1.6 & --- & $<0.005$ & $<0.010$ & 2.3 & 2.1 & 25 \\
\hline $11 / 06 / 2001$ & 1330 & 0.396 & $<0.10$ & 1.2 & --- & $<0.005$ & $<0.010$ & 2.5 & 3.0 & 30 \\
\hline $11 / 26 / 2001$ & 1510 & 0.340 & $<0.10$ & 1.0 & --- & $<0.005$ & $<0.010$ & 3.7 & 3.8 & 30 \\
\hline $12 / 10 / 2001$ & 1500 & 0.396 & $<0.10$ & 1.1 & --- & $<0.005$ & 0.020 & 1.1 & 1.3 & 30 \\
\hline $12 / 18 / 2001$ & 930 & 24.6 & 0.30 & 2.2 & 2.5 & $<0.005$ & 0.060 & 3.5 & 3.8 & 102 \\
\hline $01 / 03 / 2002$ & 1105 & 1.02 & $<0.10$ & 2.2 & --- & $<0.005$ & $<0.010$ & 3.6 & 3.8 & 28 \\
\hline $01 / 14 / 2002$ & 1400 & 0.708 & $<0.10$ & 1.9 & --- & $<0.005$ & $<0.010$ & 2.1 & 2.5 & 20 \\
\hline $02 / 06 / 2002$ & 1030 & 7.53 & $<0.10$ & 1.7 & --- & $<0.005$ & $<0.010$ & 1.9 & 2.0 & 16 \\
\hline $02 / 20 / 2002$ & 1300 & 10.4 & 0.40 & 0.91 & 1.3 & 0.020 & 0.040 & 2.8 & 2.8 & 37 \\
\hline $03 / 05 / 2002$ & 1510 & 3.51 & $<0.10$ & 0.97 & --- & 0.020 & $<0.010$ & 1.7 & 2.0 & 20 \\
\hline $03 / 18 / 2002$ & 1630 & 0 & $<0.10$ & 0.69 & --- & 0.010 & $<0.010$ & 1.3 & 1.3 & 7 \\
\hline $04 / 02 / 2002$ & 1515 & 0 & 0.20 & 1.1 & 1.3 & $<0.005$ & $<0.010$ & 0.8 & 2.0 & 15 \\
\hline $04 / 15 / 2002$ & 1615 & 0 & $<0.10$ & 1.2 & --- & $<0.005$ & $<0.010$ & 1.0 & 1.2 & 15 \\
\hline $04 / 30 / 2002$ & 1245 & 0 & $<0.10$ & 0.68 & --- & 0.020 & $<0.010$ & 0.9 & 1.2 & 9 \\
\hline $05 / 13 / 2002$ & 1630 & 0 & 0.60 & 0.85 & 1.4 & 0.020 & 0.060 & 4.1 & 4.5 & 20 \\
\hline $05 / 29 / 2002$ & 815 & 0 & $<0.10$ & 0.87 & --- & 0.020 & $<0.010$ & 2.0 & 1.9 & 12 \\
\hline $06 / 17 / 2002$ & 1645 & 0 & $<0.10$ & 1.0 & --- & 0.020 & 0.020 & 1.4 & 1.3 & 7 \\
\hline 07/08/2002 & 1230 & 0 & 0.40 & 0.79 & 1.2 & 0.010 & 0.030 & 1.9 & 2.2 & 5 \\
\hline
\end{tabular}


Appendix 1. Water-quality data results modified from NWIS data for White River near Fayetteville (07048600), Richland Creek at Goshen (07048800), and War Eagle Creek near Hindsville (07049000).-Continued

[Units are in milligrams per liter unless otherwise noted; $\mathrm{m}^{3} / \mathrm{s}$, cubic meter per second; five-digit numbers in parentheses are STORET parameter codes used for computer storage of data; N, nitrogen; p, phosphorus; <, less than; --, missing data. When laboratory reporting limit (LRL) values were originally reported, less than values were modified by dividing the LRL by 2 to get the long-term method detection level (LT-MDL) and the resulting LT-MDL value is reported below]

\begin{tabular}{|c|c|c|c|c|c|c|c|c|c|c|}
\hline Date & Time & $\begin{array}{c}\text { Instan- } \\
\text { taneous } \\
\text { streamflow, } \\
\text { in } \mathrm{m}^{3} / \mathrm{s} \\
(30209)\end{array}$ & $\begin{array}{c}\text { Total } \\
\text { ammonia } \\
+ \text { organic, } \\
\text { as } \mathrm{N} \\
(00625)\end{array}$ & $\begin{array}{c}\text { Dissolved } \\
\text { nitrite + } \\
\text { nitrate, } \\
\text { as N } \\
\text { (00631) }\end{array}$ & $\begin{array}{c}\text { Total } \\
\text { nitrogen } \\
(00600)\end{array}$ & $\begin{array}{c}\text { Dissolved } \\
\text { orthophos- } \\
\text { phorus, as P } \\
\text { (00671) }\end{array}$ & $\begin{array}{c}\text { Total } \\
\text { phosphorus } \\
(00665)\end{array}$ & $\begin{array}{c}\text { Dissolved } \\
\text { organic } \\
\text { carbon } \\
\text { (00681) }\end{array}$ & $\begin{array}{c}\text { Total } \\
\text { organic } \\
\text { carbon } \\
(00680)\end{array}$ & $\begin{array}{c}\text { Sus- } \\
\text { pended } \\
\text { sediment } \\
(\mathbf{8 0 1 5 4 )}\end{array}$ \\
\hline 07/22/2002 & 1500 & 0 & 0.30 & 0.35 & 0.65 & $<0.005$ & 0.030 & 2.5 & 2.3 & 7 \\
\hline 08/20/2002 & 1440 & 0 & 0.30 & 0.85 & 1.1 & $<0.005$ & 0.030 & 1.8 & 1.8 & 8 \\
\hline 09/03/2002 & 1330 & 0 & 0.60 & 0.42 & 1.0 & $<0.005$ & $<0.010$ & 2.3 & 1.9 & 11 \\
\hline $10 / 08 / 2002$ & 930 & 0 & $<0.10$ & 0.14 & --- & $<0.005$ & $<0.010$ & 1.2 & 0.9 & 5 \\
\hline $10 / 28 / 2002$ & 1500 & 0 & $<0.10$ & 0.10 & --- & $<0.005$ & $<0.010$ & 1.5 & 1.1 & 3 \\
\hline $11 / 13 / 2002$ & 900 & 0 & $<0.10$ & 0.11 & --- & $<0.005$ & $<0.010$ & 1.5 & 1.2 & 3 \\
\hline $12 / 11 / 2002$ & 1300 & 0.227 & $<0.10$ & 0.89 & --- & $<0.005$ & 0.030 & 1.1 & 1.0 & 4 \\
\hline $12 / 18 / 2002$ & 1400 & 1.13 & 0.20 & 1.3 & 1.5 & $<0.005$ & $<0.010$ & 2.0 & 2.0 & 11 \\
\hline $01 / 08 / 2003$ & 830 & 1.39 & $<0.10$ & 1.7 & --- & 0.020 & $<0.010$ & 1.9 & 2.0 & 6 \\
\hline $01 / 22 / 2003$ & 1110 & 0.510 & $<0.10$ & 1.5 & --- & $<0.005$ & $<0.010$ & 0.8 & 1.0 & 5 \\
\hline $02 / 12 / 2003$ & 940 & 0.261 & $<0.10$ & 1.1 & --- & $<0.005$ & $<0.010$ & 1.8 & 3.5 & 1 \\
\hline $03 / 12 / 2003$ & 745 & 1.44 & $<0.10$ & 1.2 & --- & $<0.005$ & $<0.010$ & 1.0 & 1.3 & 4 \\
\hline $03 / 25 / 2003$ & 1415 & 4.96 & $<0.10$ & 0.84 & --- & $<0.005$ & $<0.010$ & 1.2 & 1.1 & 8 \\
\hline 04/08/2003 & 1345 & 1.27 & $<0.10$ & 0.72 & --- & $<0.005$ & $<0.010$ & 1.0 & 0.9 & 19 \\
\hline $05 / 05 / 2003$ & 1430 & 1.50 & $<0.10$ & 0.40 & --- & $<0.005$ & $<0.010$ & 0.9 & 0.7 & 30 \\
\hline 06/02/2003 & 2300 & 18.3 & 0.70 & 0.63 & 1.3 & 0.020 & 0.090 & 4.7 & 4.5 & 60 \\
\hline 06/05/2003 & 1345 & 3.37 & $<0.10$ & 0.64 & --- & 0.010 & $<0.010$ & 1.4 & 1.3 & 24 \\
\hline 07/29/2003 & 1540 & 0.0680 & 0.60 & 0.09 & 0.69 & $<0.005$ & 0.050 & 2.5 & 2.5 & 28 \\
\hline $08 / 20 / 2003$ & 1120 & 0.0198 & 0.30 & 0.01 & --- & $<0.005$ & $<0.010$ & 1.6 & 1.4 & 19 \\
\hline 09/09/2003 & 1235 & 0.130 & 0.30 & 0.56 & 0.86 & $<0.005$ & $<0.010$ & 2.0 & 1.8 & 23 \\
\hline $10 / 28 / 2003$ & 1200 & 0.340 & 0.20 & 0.85 & 1.1 & $<0.005$ & $<0.010$ & 1.2 & 1.0 & 24 \\
\hline $11 / 18 / 2003$ & 1215 & 11.6 & 0.40 & 0.81 & 1.2 & 0.010 & 0.060 & 2.9 & 2.7 & 48 \\
\hline $11 / 19 / 2003$ & 845 & 8.41 & 0.30 & 0.84 & 1.1 & $<0.005$ & 0.030 & 2.5 & 2.5 & 28 \\
\hline $12 / 09 / 2003$ & 1130 & 1.47 & $<0.10$ & 1.1 & --- & $<0.005$ & $<0.010$ & 1.1 & 1.0 & 28 \\
\hline $01 / 21 / 2004$ & 1245 & 4.76 & $<0.10$ & 1.1 & --- & $<0.005$ & 0.010 & 1.7 & 1.9 & 22 \\
\hline $02 / 18 / 2004$ & 1245 & 2.38 & $<0.10$ & 1.1 & --- & $<0.005$ & 0.010 & 1.0 & 1.0 & 46 \\
\hline 03/17/2004 & 1030 & 2.04 & $<0.10$ & 0.86 & --- & $<0.005$ & 0.010 & 0.8 & 0.7 & 26 \\
\hline $04 / 13 / 2004$ & 1440 & 3.74 & $<0.10$ & 0.28 & --- & $<0.005$ & $<0.010$ & 1.1 & 1.1 & 17 \\
\hline $04 / 22 / 2004$ & 1715 & 36.0 & 0.70 & 0.58 & 1.3 & 0.030 & 0.120 & 5.2 & 5.3 & 119 \\
\hline 05/19/2004 & 930 & 2.41 & $<0.10$ & 0.60 & --- & $<0.005$ & $<0.010$ & 1.4 & 1.1 & 34 \\
\hline $06 / 23 / 2004$ & 850 & 13.8 & 0.30 & 0.66 & 0.96 & $<0.005$ & 0.050 & 3.7 & 3.8 & 41 \\
\hline $07 / 21 / 2004$ & 940 & 1.36 & 0.18 & 1.17 & 1.3 & $<0.010$ & $<0.020$ & 1.1 & 2.6 & 33 \\
\hline 08/11/2004 & 1530 & 0.878 & 0.13 & 0.89 & 1.0 & $<0.010$ & $<0.020$ & 1.1 & 1.5 & 26 \\
\hline 09/08/2004 & 1250 & 0.159 & 0.16 & 0.38 & 0.55 & $<0.010$ & $<0.020$ & 1.3 & 2.0 & 25 \\
\hline $10 / 05 / 2004$ & 1330 & 0.0538 & 0.17 & 0.031 & 0.20 & $<0.003$ & 0.013 & 1.3 & 3.2 & 23 \\
\hline $11 / 01 / 2004$ & 1700 & 68.5 & 1.0 & 1.1 & 2.1 & 0.042 & 0.220 & 5.3 & 12.3 & 351 \\
\hline
\end{tabular}


Appendix 1. Water-quality data results modified from NWIS data for White River near Fayetteville (07048600), Richland Creek at Goshen (07048800), and War Eagle Creek near Hindsville (07049000).-Continued

[Units are in milligrams per liter unless otherwise noted; $\mathrm{m}^{3} / \mathrm{s}$, cubic meter per second; five-digit numbers in parentheses are STORET parameter codes used for computer storage of data; N, nitrogen; $\mathrm{p}$, phosphorus; $<$, less than; --, missing data. When laboratory reporting limit (LRL) values were originally reported, less than values were modified by dividing the LRL by 2 to get the long-term method detection level (LT-MDL) and the resulting LT-MDL value is reported below]

\begin{tabular}{|c|c|c|c|c|c|c|c|c|c|c|}
\hline Date & Time & $\begin{array}{c}\text { Instan- } \\
\text { taneous } \\
\text { streamflow, } \\
\text { in } \mathrm{m}^{3} / \mathrm{s} \\
(30209)\end{array}$ & $\begin{array}{c}\text { Total } \\
\text { ammonia } \\
+ \text { organic, } \\
\text { as } N \\
\text { (00625) }\end{array}$ & $\begin{array}{c}\text { Dissolved } \\
\text { nitrite + } \\
\text { nitrate, } \\
\text { as N } \\
\text { (00631) }\end{array}$ & $\begin{array}{c}\text { Total } \\
\text { nitrogen } \\
(00600)\end{array}$ & $\begin{array}{c}\text { Dissolved } \\
\text { orthophos- } \\
\text { phorus, as P } \\
\text { (00671) }\end{array}$ & $\begin{array}{c}\text { Total } \\
\text { phosphorus } \\
\text { (00665) }\end{array}$ & $\begin{array}{c}\text { Dissolved } \\
\text { organic } \\
\text { carbon } \\
\text { (00681) }\end{array}$ & $\begin{array}{c}\text { Total } \\
\text { organic } \\
\text { carbon } \\
(00680)\end{array}$ & $\begin{array}{c}\text { Sus- } \\
\text { pended } \\
\text { sediment } \\
(80154)\end{array}$ \\
\hline $11 / 03 / 2004$ & 1315 & 12.1 & 0.24 & 3.9 & 4.1 & 0.014 & 0.043 & 1.9 & 3.2 & 43 \\
\hline $01 / 04 / 2005$ & 855 & 61.4 & 1.6 & 0.868 & 2.5 & 0.078 & 0.440 & 5.7 & 19.5 & 1050 \\
\hline $01 / 11 / 2005$ & 1400 & 1.59 & 0.10 & 1.51 & 1.6 & 0.006 & 0.019 & 1.1 & 1.4 & 26 \\
\hline $03 / 07 / 2005$ & 1330 & 2.55 & 0.09 & 0.592 & 0.68 & $<0.003$ & 0.007 & 0.9 & 1.3 & 4 \\
\hline $04 / 18 / 2005$ & 1430 & 4.62 & 0.12 & 0.454 & 0.57 & $<0.015$ & 0.012 & 1.5 & 1.0 & 6 \\
\hline $06 / 28 / 2005$ & 1445 & 0.159 & 0.30 & 0.049 & 0.35 & $<0.003$ & 0.021 & 1.5 & 2.3 & 9 \\
\hline $08 / 15 / 2005$ & 1430 & 0.0311 & 0.29 & 0.014 & 0.31 & $<0.020$ & 0.028 & 9.7 & 3.5 & 16 \\
\hline $10 / 19 / 2005$ & 1230 & 0.0116 & 0.27 & 0.018 & 0.29 & $<0.015$ & 0.023 & 3.9 & 2.4 & 35 \\
\hline $12 / 19 / 2005$ & 1330 & 0.0136 & 0.14 & 0.040 & --- & $<0.015$ & 0.009 & 1.0 & 3.9 & 60 \\
\hline $02 / 22 / 2006$ & 1410 & 0.139 & 0.11 & 0.257 & 0.37 & $<0.015$ & 0.007 & 1.0 & 1.5 & 2 \\
\hline $05 / 04 / 2006$ & 1700 & 84.4 & 1.0 & 0.356 & 1.4 & 0.037 & 0.220 & 7.8 & 15.3 & 363 \\
\hline $05 / 23 / 2006$ & 1230 & 0.736 & 0.16 & 0.369 & 0.53 & $<0.003$ & 0.009 & 1.3 & 2.8 & 3 \\
\hline 07/19/2006 & 815 & 0.0272 & 0.26 & 0.012 & 0.27 & 0.003 & 0.016 & 1.6 & 2.2 & 4 \\
\hline $08 / 23 / 2006$ & 1415 & 8.98 & 1.4 & 2.11 & 3.5 & 0.207 & 0.430 & 8.5 & 13.3 & 143 \\
\hline 08/29/2006 & 1355 & 0.235 & 0.28 & 1.31 & 1.6 & 0.007 & 0.020 & 2.3 & 2.9 & 5 \\
\hline $10 / 31 / 2006$ & 1315 & 0.708 & 0.20 & 1.44 & 1.6 & 0.004 & 0.017 & 8.2 & 2.6 & 5 \\
\hline $12 / 13 / 2006$ & 1320 & 0.263 & 0.16 & 2.0 & 2.2 & 0.006 & 0.015 & 25.4 & 1.5 & 7 \\
\hline $01 / 13 / 2007$ & 1715 & 116 & 1.6 & 0.581 & 2.2 & 0.063 & 0.340 & 5.0 & 17.6 & 876 \\
\hline $02 / 13 / 2007$ & 1400 & 29.7 & 0.49 & 0.805 & 1.3 & 0.021 & 0.094 & 4.0 & 5.9 & 55 \\
\hline $02 / 20 / 2007$ & 1515 & 3.40 & $<0.05$ & 1.36 & --- & 0.006 & 0.008 & 0.9 & 1.2 & 6 \\
\hline $05 / 29 / 2007$ & 1400 & 0.680 & 0.12 & 0.313 & 0.43 & 0.004 & 0.009 & 1.0 & 1.4 & 6 \\
\hline 07/09/2007 & 1500 & 0.396 & 0.20 & 0.226 & 0.42 & 0.003 & 0.015 & 1.8 & 2.2 & 5 \\
\hline 09/04/2007 & 1600 & 0.0850 & 0.25 & 0.035 & 0.29 & 0.007 & 0.019 & 2.0 & 2.4 & 6 \\
\hline $10 / 22 / 2007$ & 1130 & 0.235 & 0.14 & 0.220 & 0.36 & 0.004 & 0.008 & 1.5 & 1.6 & 2 \\
\hline $01 / 14 / 2008$ & 1155 & 0.595 & 0.11 & 0.894 & 1.0 & 0.004 & 0.008 & 1.2 & 1.1 & 5 \\
\hline $02 / 17 / 2008$ & 1230 & 50.1 & 0.78 & 1.21 & 2.0 & 0.050 & 0.208 & 6.7 & 8.6 & 89 \\
\hline $02 / 25 / 2008$ & 1448 & 2.63 & 0.11 & 1.86 & 2.0 & 0.007 & 0.013 & 1.2 & 1.2 & 5 \\
\hline 03/19/2008 & 1310 & 762 & 1.0 & 0.853 & 1.9 & 0.052 & 0.330 & 6.6 & 10.4 & 428 \\
\hline $04 / 10 / 2008$ & 1720 & 1270 & 1.4 & 0.559 & 2.0 & 0.027 & 0.330 & 3.9 & 13.3 & 582 \\
\hline 05/06/2008 & 1040 & 65.4 & 0.12 & 0.669 & 0.79 & 0.006 & 0.016 & 1.0 & 1.4 & 14 \\
\hline 06/09/2008 & 1010 & 74.8 & 0.24 & 0.531 & 0.77 & 0.003 & 0.029 & 1.4 & 1.6 & 13 \\
\hline 08/26/2008 & 1042 & 35.7 & 0.43 & 1.03 & 1.5 & 0.004 & 0.047 & 2.3 & 3.5 & 18 \\
\hline 09/04/2008 & 1300 & 47.3 & 0.59 & 1.27 & 1.9 & 0.048 & 0.116 & 5.0 & 7.6 & 27 \\
\hline \multicolumn{11}{|c|}{ War Eagle Creek near Hindsville (07049000) } \\
\hline $04 / 05 / 2001$ & 830 & 2.15 & $<0.10$ & 1.5 & --- & 0.030 & 0.030 & 1.8 & --- & 19 \\
\hline $04 / 17 / 2001$ & 1400 & 4.53 & 0.21 & 0.89 & 1.1 & 0.020 & 0.030 & 2.0 & 2.4 & 21 \\
\hline
\end{tabular}


Appendix 1. Water-quality data results modified from NWIS data for White River near Fayetteville (07048600), Richland Creek at Goshen (07048800), and War Eagle Creek near Hindsville (07049000)._-Continued

[Units are in milligrams per liter unless otherwise noted; $\mathrm{m}^{3} / \mathrm{s}$, cubic meter per second; five-digit numbers in parentheses are STORET parameter codes used for computer storage of data; N, nitrogen; p, phosphorus; <, less than; --, missing data. When laboratory reporting limit (LRL) values were originally reported, less than values were modified by dividing the LRL by 2 to get the long-term method detection level (LT-MDL) and the resulting LT-MDL value is reported below]

\begin{tabular}{|c|c|c|c|c|c|c|c|c|c|c|}
\hline Date & Time & $\begin{array}{c}\text { Instan- } \\
\text { taneous } \\
\text { streamflow, } \\
\text { in } \mathrm{m}^{3} / \mathrm{s} \\
(30209)\end{array}$ & $\begin{array}{c}\text { Total } \\
\text { ammonia } \\
+ \text { organic, } \\
\text { as N } \\
\text { (00625) }\end{array}$ & $\begin{array}{c}\text { Dissolved } \\
\text { nitrite + } \\
\text { nitrate, } \\
\text { as N } \\
\text { (00631) }\end{array}$ & $\begin{array}{c}\text { Total } \\
\text { nitrogen } \\
(00600)\end{array}$ & $\begin{array}{c}\text { Dissolved } \\
\text { orthophos- } \\
\text { phorus, as P } \\
\text { (00671) }\end{array}$ & $\begin{array}{c}\text { Total } \\
\text { phosphorus } \\
\text { (00665) }\end{array}$ & $\begin{array}{c}\text { Dissolved } \\
\text { organic } \\
\text { carbon } \\
\text { (00681) }\end{array}$ & $\begin{array}{c}\text { Total } \\
\text { organic } \\
\text { carbon } \\
(00680)\end{array}$ & $\begin{array}{c}\text { Sus- } \\
\text { pended } \\
\text { sediment } \\
(80154)\end{array}$ \\
\hline $05 / 02 / 2001$ & 745 & 1.56 & 0.36 & 0.84 & 1.2 & 0.020 & 0.020 & 1.0 & 1.2 & 22 \\
\hline $05 / 16 / 2001$ & 850 & 1.33 & 0.42 & 1.0 & 1.4 & 0.050 & 0.070 & 1.7 & 1.3 & 28 \\
\hline $05 / 30 / 2001$ & 800 & 1.67 & 0.26 & 1.1 & 1.4 & 0.030 & 0.020 & 1.5 & 1.4 & 25 \\
\hline $06 / 12 / 2001$ & 800 & 0.934 & 0.24 & 1.0 & 1.2 & 0.050 & 0.040 & 2.2 & 2.1 & 27 \\
\hline $06 / 25 / 2001$ & 1330 & 0.793 & 0.21 & 0.94 & 1.1 & 0.020 & 0.020 & 1.0 & 0.8 & 23 \\
\hline 07/09/2001 & 1215 & 0.991 & 0.20 & 1.3 & 1.5 & 0.030 & 0.040 & 2.2 & 1.6 & 28 \\
\hline $07 / 24 / 2001$ & 1400 & 0.651 & 0.26 & 0.84 & 1.1 & 0.030 & 0.050 & 1.3 & 1.0 & 26 \\
\hline 08/07/2001 & 615 & 0.425 & 0.30 & 0.76 & 1.1 & $<0.005$ & 0.020 & 2.4 & 1.8 & 32 \\
\hline $08 / 21 / 2001$ & 1130 & 0.368 & 0.30 & 0.41 & 0.71 & $<0.005$ & $<0.010$ & 2.9 & 1.8 & 42 \\
\hline $09 / 05 / 2001$ & 730 & 0.481 & $<0.10$ & 0.78 & --- & $<0.005$ & $<0.010$ & 2.2 & 2.5 & 31 \\
\hline $09 / 18 / 2001$ & 930 & 0.850 & 0.20 & 1.9 & 2.1 & 0.040 & 0.050 & 2.9 & 2.3 & 25 \\
\hline $10 / 04 / 2001$ & 800 & 0.510 & $<0.10$ & 1.2 & --- & 0.040 & 0.050 & 1.6 & 1.5 & 36 \\
\hline $10 / 16 / 2001$ & 1530 & 3.40 & $<0.10$ & 0.86 & --- & 0.050 & 0.050 & 3.0 & 2.9 & 26 \\
\hline $11 / 01 / 2001$ & 730 & 0.623 & $<0.10$ & 1.2 & --- & 0.020 & 0.030 & 1.7 & 1.7 & 23 \\
\hline $11 / 06 / 2001$ & 1215 & 0.651 & 0.30 & 1.3 & 1.6 & 0.030 & 0.040 & 5.3 & 5.4 & 34 \\
\hline $11 / 26 / 2001$ & 1645 & 1.58 & $<0.10$ & 1.2 & --- & 0.060 & 0.070 & 3.5 & 3.8 & 39 \\
\hline $12 / 13 / 2001$ & 715 & 2.97 & $<0.10$ & 1.0 & --- & 0.070 & 0.070 & 1.9 & 1.9 & 30 \\
\hline $12 / 18 / 2001$ & 815 & 77.0 & 0.50 & 1.9 & 2.4 & 0.020 & 0.080 & 4.4 & 6.7 & 95 \\
\hline $01 / 03 / 2002$ & 1315 & 2.35 & $<0.10$ & 2.2 & --- & 0.040 & 0.050 & 3.7 & 3.8 & 26 \\
\hline $01 / 16 / 2002$ & 1530 & 1.61 & $<0.10$ & 2.1 & --- & 0.080 & 0.080 & 0.7 & 0.6 & 24 \\
\hline $02 / 06 / 2002$ & 930 & 12.1 & $<0.10$ & 1.7 & --- & 0.010 & 0.020 & 1.8 & 1.9 & 20 \\
\hline $02 / 20 / 2002$ & 1545 & 16.0 & 0.30 & 1.0 & 1.3 & 0.020 & 0.050 & 1.7 & 2.1 & 46 \\
\hline $03 / 07 / 2002$ & 1530 & 8.89 & $<0.10$ & 0.87 & --- & 0.040 & 0.030 & 2.4 & --- & 23 \\
\hline $03 / 18 / 2002$ & 1530 & 8.61 & 0.20 & 0.80 & 1.0 & $<0.005$ & $<0.010$ & 1.6 & 1.6 & 32 \\
\hline $04 / 02 / 2002$ & 1400 & 10.1 & $<0.10$ & 1.3 & --- & $<0.005$ & 0.020 & 0.9 & 1.8 & 26 \\
\hline $04 / 16 / 2002$ & 1100 & 10.7 & $<0.10$ & 1.4 & --- & 0.020 & 0.020 & 1.2 & 1.2 & 11 \\
\hline $04 / 30 / 2002$ & 1145 & 10.6 & $<0.10$ & 0.71 & --- & 0.020 & 0.030 & 1.2 & 1.3 & 10 \\
\hline $05 / 13 / 2002$ & 1500 & 12.8 & 1.4 & 1.1 & 2.5 & 0.040 & 0.060 & 2.0 & 2.1 & 16 \\
\hline $05 / 29 / 2002$ & 715 & 9.68 & $<0.10$ & 1.4 & --- & 0.030 & $<0.010$ & 1.5 & 1.4 & 15 \\
\hline $06 / 17 / 2002$ & 1530 & 8.21 & $<0.10$ & 1.4 & --- & 0.020 & 0.020 & 1.3 & 1.4 & 12 \\
\hline $07 / 08 / 2002$ & 1345 & 2.10 & $<0.10$ & 1.4 & --- & 0.030 & 0.040 & 1.6 & 1.7 & 7 \\
\hline $07 / 22 / 2002$ & 1330 & 3.26 & 0.20 & 1.4 & 1.6 & 0.070 & 0.060 & 2.1 & 1.3 & 8 \\
\hline $08 / 20 / 2002$ & 1615 & 2.83 & $<0.10$ & 1.9 & --- & 0.030 & 0.060 & 2.3 & 2.3 & 11 \\
\hline $09 / 03 / 2002$ & 1230 & 0.680 & 0.30 & 1.4 & 1.7 & $<0.005$ & $<0.010$ & 1.4 & 1.1 & 12 \\
\hline $10 / 08 / 2002$ & 830 & 0.425 & $<0.10$ & 1.4 & --- & $<0.005$ & $<0.010$ & 1.2 & 1.1 & 4 \\
\hline $10 / 28 / 2002$ & 1350 & 1.05 & $<0.10$ & 1.6 & --- & $<0.005$ & $<0.010$ & 1.4 & 1.2 & 1 \\
\hline
\end{tabular}


Appendix 1. Water-quality data results modified from NWIS data for White River near Fayetteville (07048600), Richland Creek at Goshen (07048800), and War Eagle Creek near Hindsville (07049000).-Continued

[Units are in milligrams per liter unless otherwise noted; $\mathrm{m}^{3} / \mathrm{s}$, cubic meter per second; five-digit numbers in parentheses are STORET parameter codes used for computer storage of data; N, nitrogen; p, phosphorus; <, less than; --, missing data. When laboratory reporting limit (LRL) values were originally reported, less than values were modified by dividing the LRL by 2 to get the long-term method detection level (LT-MDL) and the resulting LT-MDL value is reported below]

\begin{tabular}{|c|c|c|c|c|c|c|c|c|c|c|}
\hline Date & Time & $\begin{array}{c}\text { Instan- } \\
\text { taneous } \\
\text { streamflow, } \\
\text { in } \mathrm{m}^{3} / \mathrm{s} \\
(30209)\end{array}$ & $\begin{array}{c}\text { Total } \\
\text { ammonia } \\
+ \text { organic, } \\
\text { as } N \\
(00625)\end{array}$ & $\begin{array}{c}\text { Dissolved } \\
\text { nitrite + } \\
\text { nitrate, } \\
\text { as } N \\
\text { (00631) }\end{array}$ & $\begin{array}{c}\text { Total } \\
\text { nitrogen } \\
(00600)\end{array}$ & $\begin{array}{c}\text { Dissolved } \\
\text { orthophos- } \\
\text { phorus, as P } \\
\text { (00671) }\end{array}$ & $\begin{array}{c}\text { Total } \\
\text { phosphorus } \\
\text { (00665) }\end{array}$ & $\begin{array}{c}\text { Dissolved } \\
\text { organic } \\
\text { carbon } \\
\text { (00681) }\end{array}$ & $\begin{array}{c}\text { Total } \\
\text { organic } \\
\text { carbon } \\
(00680)\end{array}$ & $\begin{array}{c}\text { Sus- } \\
\text { pended } \\
\text { sediment } \\
(80154)\end{array}$ \\
\hline $11 / 13 / 2002$ & 800 & 0.736 & $<0.10$ & 1.6 & --- & 0.030 & 0.040 & 1.4 & 1.4 & 3 \\
\hline $12 / 09 / 2002$ & 1445 & 1.33 & 0.30 & 1.8 & 2.1 & 0.040 & 0.060 & 1.3 & 1.5 & $<0.5$ \\
\hline $12 / 19 / 2002$ & 845 & 1.93 & 0.40 & 2.1 & 2.5 & 0.190 & 0.210 & 2.1 & 2.7 & 7 \\
\hline $01 / 07 / 2003$ & 1045 & 3.48 & $<0.10$ & 1.6 & --- & 0.030 & 0.050 & 1.3 & 1.5 & 5 \\
\hline $01 / 22 / 2003$ & 1245 & 0.821 & $<0.10$ & 1.5 & --- & 0.080 & 0.110 & 1.6 & 1.7 & 2 \\
\hline $02 / 12 / 2003$ & 830 & 0.453 & 0.20 & 1.3 & 1.5 & 0.040 & 0.050 & 1.8 & 2.9 & 3 \\
\hline $03 / 11 / 2003$ & 1220 & 3.40 & $<0.10$ & 1.3 & --- & $<0.005$ & $<0.010$ & 1.0 & 1.0 & 6 \\
\hline $03 / 25 / 2003$ & 1245 & 9.71 & $<0.10$ & 1.0 & --- & 0.020 & 0.050 & 1.2 & 1.1 & 13 \\
\hline 04/09/2003 & 730 & 2.86 & $<0.10$ & 0.98 & --- & 0.020 & 0.050 & 1.3 & 1.1 & 25 \\
\hline $05 / 05 / 2003$ & 1300 & 3.06 & $<0.10$ & 0.51 & --- & 0.020 & 0.040 & 1.1 & 1.0 & 35 \\
\hline $06 / 03 / 2003$ & 745 & 21.3 & 0.30 & 0.61 & 0.91 & 0.010 & 0.070 & 2.0 & 1.9 & 66 \\
\hline $06 / 05 / 2003$ & 1215 & 7.39 & $<0.10$ & 0.88 & --- & 0.030 & 0.050 & 2.0 & 2.2 & 32 \\
\hline $07 / 29 / 2003$ & 1445 & 0.510 & 0.20 & 0.94 & 1.1 & 0.030 & 0.040 & 1.6 & 1.3 & 37 \\
\hline $08 / 20 / 2003$ & 1025 & 0.368 & 0.20 & 0.54 & 0.74 & $<0.005$ & 0.010 & 1.8 & 1.5 & 27 \\
\hline 09/09/2003 & 1130 & 0.453 & 0.20 & 1.6 & 1.8 & 0.020 & 0.030 & 1.6 & 1.6 & 27 \\
\hline $10 / 28 / 2003$ & 1100 & 0.878 & 0.30 & 0.97 & 1.3 & 0.090 & 0.080 & 1.5 & 1.5 & 21 \\
\hline $11 / 18 / 2003$ & 1655 & 21.8 & 0.50 & 0.79 & 1.3 & 0.100 & 0.180 & 2.0 & 1.9 & 89 \\
\hline $11 / 19 / 2003$ & 1115 & 13.0 & 0.50 & 0.70 & 1.2 & 0.020 & 0.080 & 3.3 & 4.2 & 45 \\
\hline $12 / 09 / 2003$ & 1000 & 2.29 & $<0.10$ & 1.2 & --- & 0.040 & 0.050 & 1.0 & 1.0 & 28 \\
\hline $01 / 21 / 2004$ & 1130 & 9.00 & $<0.10$ & 0.69 & --- & $<0.005$ & 0.020 & 1.5 & 1.6 & 28 \\
\hline $02 / 18 / 2004$ & 1045 & 4.67 & $<0.10$ & 1.1 & --- & $<0.005$ & 0.020 & 0.9 & 0.9 & 45 \\
\hline $03 / 17 / 2004$ & 930 & 3.82 & $<0.10$ & 1.0 & --- & 0.040 & 0.060 & 0.9 & 0.7 & 30 \\
\hline $04 / 13 / 2004$ & 1625 & 6.65 & $<0.10$ & 0.42 & --- & 0.020 & 0.040 & 1.4 & 1.3 & 12 \\
\hline $04 / 22 / 2004$ & 1800 & 129 & 1.2 & 0.43 & 1.6 & 0.020 & 0.240 & 7.1 & 6.6 & 267 \\
\hline $05 / 19 / 2004$ & 830 & 5.55 & $<0.10$ & 1.3 & --- & $<0.005$ & $<0.010$ & 1.4 & 1.3 & 35 \\
\hline $06 / 23 / 2004$ & 725 & 6.65 & $<0.10$ & 1.3 & --- & 0.030 & 0.060 & 1.8 & 1.9 & 43 \\
\hline $07 / 21 / 2004$ & 830 & 1.64 & 0.11 & 1.1 & 1.2 & 0.020 & $<0.020$ & 1.1 & 2.1 & 30 \\
\hline $08 / 11 / 2004$ & 1400 & 1.33 & 0.18 & 1.23 & 1.4 & 0.020 & 0.050 & 1.2 & 2.6 & 34 \\
\hline 09/08/2004 & 1100 & 0.340 & 0.16 & 1.57 & 1.7 & $<0.010$ & 0.030 & 1.1 & 1.7 & 34 \\
\hline $10 / 05 / 2004$ & 1045 & 0.283 & 0.15 & 1.24 & 1.4 & 0.006 & 0.019 & 1.1 & 3.1 & 54 \\
\hline $11 / 02 / 2004$ & 1115 & 51.0 & 0.60 & 1.2 & 1.8 & 0.023 & 0.138 & 4.3 & 7.2 & 133 \\
\hline $11 / 03 / 2004$ & 925 & 56.9 & 0.36 & 1.57 & 1.9 & 0.023 & 0.078 & 2.4 & 4.4 & 61 \\
\hline $01 / 04 / 2005$ & 1230 & 48.7 & 1.4 & 1.38 & 2.7 & 0.044 & 0.300 & 3.9 & 15.5 & 454 \\
\hline $01 / 11 / 2005$ & 1250 & 17.3 & 0.13 & 1.91 & 2.0 & 0.017 & 0.038 & 1.4 & 1.6 & 38 \\
\hline $03 / 08 / 2005$ & 815 & 7.11 & 0.12 & 0.931 & 1.1 & $<0.003$ & 0.018 & 1.1 & 1.3 & 8 \\
\hline $04 / 19 / 2005$ & 800 & 8.33 & 0.12 & 0.709 & 0.83 & $<0.003$ & 0.036 & 1.0 & 1.7 & 13 \\
\hline
\end{tabular}


Appendix 1. Water-quality data results modified from NWIS data for White River near Fayetteville (07048600), Richland Creek at Goshen (07048800), and War Eagle Creek near Hindsville (07049000).-Continued

[Units are in milligrams per liter unless otherwise noted; $\mathrm{m}^{3} / \mathrm{s}$, cubic meter per second; five-digit numbers in parentheses are STORET parameter codes used for computer storage of data; N, nitrogen; p, phosphorus; <, less than; --, missing data. When laboratory reporting limit (LRL) values were originally reported, less than values were modified by dividing the LRL by 2 to get the long-term method detection level (LT-MDL) and the resulting LT-MDL value is reported below]

\begin{tabular}{|c|c|c|c|c|c|c|c|c|c|c|}
\hline Date & Time & $\begin{array}{c}\text { Instan- } \\
\text { taneous } \\
\text { streamflow, } \\
\text { in } \mathrm{m}^{3} / \mathrm{s} \\
(30209)\end{array}$ & $\begin{array}{c}\text { Total } \\
\text { ammonia } \\
+ \text { organic, } \\
\text { as } N \\
\text { (00625) }\end{array}$ & $\begin{array}{c}\text { Dissolved } \\
\text { nitrite + } \\
\text { nitrate, } \\
\text { as N } \\
\text { (00631) }\end{array}$ & $\begin{array}{c}\text { Total } \\
\text { nitrogen } \\
(00600)\end{array}$ & $\begin{array}{c}\text { Dissolved } \\
\text { orthophos- } \\
\text { phorus, as P } \\
\text { (00671) }\end{array}$ & $\begin{array}{c}\text { Total } \\
\text { phosphorus } \\
\text { (00665) }\end{array}$ & $\begin{array}{c}\text { Dissolved } \\
\text { organic } \\
\text { carbon } \\
\text { (00681) }\end{array}$ & $\begin{array}{c}\text { Total } \\
\text { organic } \\
\text { carbon } \\
(00680)\end{array}$ & $\begin{array}{c}\text { Sus- } \\
\text { pended } \\
\text { sediment } \\
(80154)\end{array}$ \\
\hline $06 / 28 / 2005$ & 1330 & 0.651 & 0.24 & 0.914 & 1.1 & 0.006 & 0.043 & 1.7 & 1.9 & 9 \\
\hline $08 / 15 / 2005$ & 1330 & 0.368 & 0.34 & 0.414 & 0.75 & $<0.020$ & 0.035 & 2.7 & 3.0 & 8 \\
\hline $10 / 19 / 2005$ & 1120 & 0.255 & 0.20 & 0.721 & 0.92 & $<0.015$ & 0.023 & 2.1 & 4.4 & 39 \\
\hline $12 / 19 / 2005$ & 1200 & 0.368 & 0.19 & 1.14 & 1.3 & 0.030 & 0.066 & 1.4 & 3.3 & 43 \\
\hline $02 / 22 / 2006$ & 1200 & 0.595 & 0.17 & 0.631 & 0.80 & 0.033 & 0.070 & 1.3 & 3.3 & 3 \\
\hline $05 / 04 / 2006$ & 1900 & 146 & 1.6 & 0.673 & 2.3 & 0.060 & 0.380 & 5.8 & 17.8 & 517 \\
\hline $05 / 23 / 2006$ & 1100 & 3.11 & 0.18 & 1.18 & 1.4 & 0.017 & 0.035 & 1.3 & 1.5 & 12 \\
\hline 07/19/2006 & 650 & 0.368 & 0.32 & 0.257 & 0.58 & 0.003 & 0.026 & 1.4 & 2.2 & 10 \\
\hline 08/29/2006 & 1240 & 0.906 & 0.31 & 1.46 & 1.8 & 0.015 & 0.041 & 1.9 & 2.7 & 8 \\
\hline $11 / 01 / 2006$ & 1100 & 1.87 & 0.20 & 1.53 & 1.7 & 0.067 & 0.100 & 21.7 & 2.2 & 6 \\
\hline $12 / 13 / 2006$ & 1040 & 6.14 & 0.12 & 2.36 & 2.5 & 0.025 & 0.051 & 29.8 & 1.5 & 10 \\
\hline $02 / 13 / 2007$ & 1300 & 96.6 & 0.79 & 0.973 & 1.8 & 0.022 & 0.194 & 4.1 & 8.1 & 146 \\
\hline $02 / 20 / 2007$ & 1630 & 8.81 & $<0.05$ & 1.84 & --- & 0.019 & 0.033 & 0.9 & 1.2 & 18 \\
\hline $05 / 30 / 2007$ & 820 & 1.87 & 0.16 & 0.968 & 1.1 & 0.014 & 0.033 & 1.1 & 1.7 & 9 \\
\hline 07/10/2007 & 1345 & 1.39 & 0.20 & 0.530 & 0.73 & 0.016 & 0.032 & 1.9 & 2.3 & 4 \\
\hline 09/04/2007 & 1510 & 0.340 & 0.21 & 0.367 & 0.58 & 0.006 & 0.025 & 1.5 & 2.7 & 5 \\
\hline $10 / 22 / 2007$ & 1245 & 0.651 & 0.20 & 1.19 & 1.4 & 0.021 & 0.035 & 1.9 & 2.0 & 3 \\
\hline $01 / 14 / 2008$ & 1047 & 2.29 & 0.21 & 0.859 & 1.1 & 0.021 & 0.049 & 2.0 & 2.4 & 9 \\
\hline $02 / 25 / 2008$ & 1327 & 5.55 & 0.13 & 2.26 & 2.4 & 0.020 & 0.040 & 1.1 & 1.5 & 8 \\
\hline $03 / 04 / 2008$ & 1030 & 111 & 0.76 & 1.73 & 2.5 & 0.025 & 0.210 & 4.0 & 8.1 & 187 \\
\hline 03/19/2008 & 1015 & 881 & 0.97 & 0.844 & 1.8 & 0.063 & 0.329 & 9.9 & 11.0 & 279 \\
\hline $04 / 10 / 2008$ & 1430 & 1060 & 2.3 & 0.347 & 2.6 & 0.056 & 0.460 & 8.2 & 21.6 & 727 \\
\hline $05 / 06 / 2008$ & 1140 & 7.84 & 0.12 & 0.999 & 1.1 & 0.008 & 0.023 & 1.1 & 1.5 & 164 \\
\hline 06/09/2008 & 1110 & 3.48 & 0.17 & 0.886 & 1.1 & 0.022 & 0.044 & 1.3 & 1.6 & 11 \\
\hline $08 / 26 / 2008$ & 957 & 1.30 & 0.26 & 1.68 & 1.9 & 0.048 & 0.075 & 1.8 & 2.0 & 11 \\
\hline 09/04/2008 & 1400 & 42.8 & 0.54 & 1.68 & 2.2 & 0.037 & 0.115 & 3.8 & 4.3 & 73 \\
\hline
\end{tabular}


Publishing support provided by: Lafayette Publishing Service Center

For more information concerning the research described in the report

U.S. Geological Survey Arkansas Water Science Center 401 Hardin Road Little Rock, AR 72211-3528

(501) 228-3600

http://ar.water.usgs.gov 
